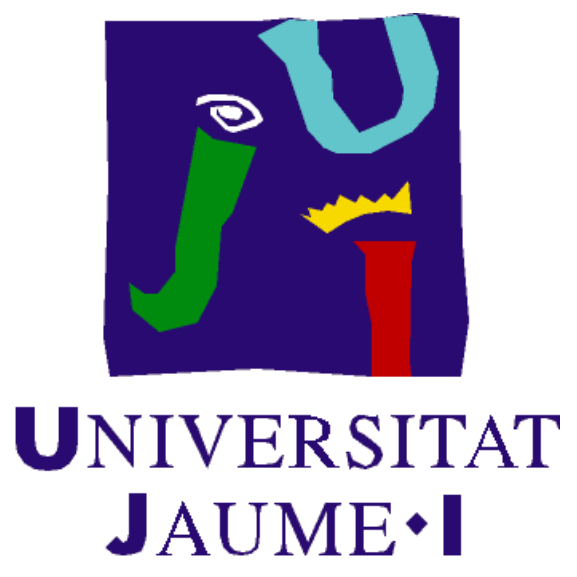

\title{
International trade and production networks in the Western Balkan countries
}

\author{
By \\ Bojan Shimbov \\ December 2015
}

Supervisors: Maite Alguacil Marí

Celestino Suárez Burguet 


\section{Table of Contents}

Pages

List of Tables $\quad 5$

$\begin{array}{ll}\text { List of Figures } & 7\end{array}$

English Acknowledgments $\quad 8$

Spanish Acknowledgments 9

English Preface 12

$\begin{array}{ll}\text { Spanish Preface } & 29\end{array}$

Chapter I: Fragmentation and parts and components trade in the Western Balkan countries

Abstract

1.1 Introduction

1.2 Stylized facts

1.3 Theoretical background of fragmentation theory 56

1.4 Related research $\quad 57$

$\begin{array}{ll}1.5 \text { Empirical analysis } & 60\end{array}$

1.5.1 Model specification and estimation methodology 60

$\begin{array}{ll}\text { 1.5.2 Data and variables } & 61\end{array}$

$\begin{array}{ll}1.6 \text { Estimation results } & 64\end{array}$

$\begin{array}{ll}1.7 \text { Conclusions } & 69\end{array}$

$\begin{array}{ll}\text { References } & 72\end{array}$

$\begin{array}{ll}\text { Appendix } & 77\end{array}$

Chapter II: International Production Networks and Economic Growth: The Case of the Western Balkan Countries

Abstract

2.1 Introduction

2.2 Related literature

2.3 Data and stylized facts 
2.3.1 Scope and distribution of processing trade in the Western Balkan 90 countries

2.3.2 Measuring the participation in processing trade 94

2.4 What is the impact of international fragmentation on Western Balkan countries 101 growth performance?

$\begin{array}{ll}2.5 \text { Conclusions } & 107\end{array}$

$\begin{array}{ll}\text { References } & 109\end{array}$

Chapter III: Export sophistication and economic growth in the Western Balkan Countries

$\begin{array}{ll}\text { Abstract } & 114\end{array}$

3.1 Introduction $\quad 115$

3.2 The evolution of the export structure of the Western Balkan countries 117

$\begin{array}{ll}3.3 \text { Related literature } & 120\end{array}$

3.4 Export sophistication of the Western Balkan countries 124

$\begin{array}{ll}\text { 3.4.1 Measuring export sophistication (EXPY) } & 124\end{array}$

3.4.2 Data availability and main PRODY and EXPY statistics 126

3.5 Evolution of export sophistication of the Western Balkan countries 129

3.6 Econometric methodology and results 134

$\begin{array}{ll}3.7 \text { Conclusions } & 140\end{array}$

References $\quad 142$

$\begin{array}{ll}\text { Appendix } & 145\end{array}$ 


\section{List of Tables}

Chapter I: Fragmentation and parts and components trade in the Western Balkan countries

Table 1. Foreign direct investment as \% of GDP 53

Table 2. Trade in machinery and transport equipment: total and parts and 54 components of the same groups, 2000-2009 (mil. USD)

Table 3. Estimation results for parts and components trade (with home-county 65 fixed effects)

Table 4. Estimation results for final goods trade (with home-county fixed effects) 66

Table A.1. Code list 77

Table A.2. Regions and countries included in the dataset 78

$\begin{array}{ll}\text { Table A.3. Definitions and data sources } & 79\end{array}$

Table A.4. Estimation results with parts and components trade with county-pair 80 fixed effects

Table A.5. Estimation results for final goods trade with country-pair fixed effects

Chapter II: International Production Networks and Economic Growth: The Case of the Western Balkan Countries

Table 1. Processing and final goods trade in the Western Balkan countries: 2002- 91 2013

Table 2. Geographical structure of the WBC inward processing trade exports 92

Table 3. Index of international fragmentation (in log) for the WBC: 2002-2013 95

Table 4. Index of international fragmentation per industries 97

Table 5. Definitions and data sources 102

Table 6. Estimation results using random effects: 2002-2013 103

Table 7. Estimation results using TSLS and GMM Instrumental Variables: 2002- 104 2013 
Chapter III: Export sophistication and economic growth in the Western Balkan Countries

Table 1. Summary of the theoretical and empirical literature on measuring export 123 sophistication

Table 2. main statistics of the PRODY indicator

Table 3. Descriptive statistics for EXPY

Table 4. Estimation results using random effects: 1996-2014

Table 5. Determinants of total EXPY and EXPY in manufactories: 1996-2014

Table A.1. Definitions and data sources 145

Table A.2. Correlation matrix 146 


\section{List of Figures}

Chapter I: Fragmentation and parts and components trade in the Western Balkan countries

Figure 1. Annual growth in parts and components trade

Chapter II: International Production Networks and Economic Growth: The Case of the Western Balkan Countries

Figure 1. Industrial structure of the WBC inward processing trade exports, as $\%$ of 93 total trade in the category: 2002-2013

Chapter III: Export sophistication and economic growth in the Western Balkan Countries

$\begin{array}{ll}\text { Figure 1. goods exports as \% of GDP } & 118\end{array}$

Figure 2. Share of manufacturing exports in total exports of goods, (in \%) 118

Figure 3. Structure of manufacturing exports by skill and technology intensity, 119 (period averages)

Figure 4. Evolution of EXPY over time 130

Figure 5. Evolution of EXPY in manufacturing products by skill and technology 131 intensity

Figure 6. Relationship between GDP per capita and EXPY in WBC, (1996-2014 132 per country)

Figure 7. Potential determinates of export sophistication, (per year) 


\section{English Acknowledgments}

Undertaking this $\mathrm{Ph} . \mathrm{D}$. Thesis has been a truly life-changing experience for me and it would not have been possible to do without the support and guidance that I received from many people.

Foremost, I would like to express my sincere and wholehearted gratitude to my mentors, Dr. Maite Alguacil Marí and Professor Celestino Suárez Burguet, for giving me the opportunity to embark on this extraordinary journey. I am deeply grateful to both of you for your fundamental role in this project. Most of all I would like to thank you for encouraging my research and for allowing me to grow as a researcher, for your continued support, patience, motivation and direction throughout this period. I am deeply honored by the opportunity to do my doctoral program under your guidance and to learn from both of you. I could not have imagined having better mentors.

I would like to convey my heartfelt thanks to the University of Jaume I of Castellon, the Department of Economics and the Institute of International Economy for offering me an ideal environment in which I felt free and could concentrate on my research. Also, I would like to thank the Project on Design of Logistics Platforms Network in Spain $(R E L O G)$ for offering financial support throughout part of my Ph.D. studies. Finally, there are so many friends, both in Spain and in Macedonia, who offered me so much kindly help. I give my sincere thanks to all of them.

Last but certainly not least, I am deeply thankful to my family for their love, support, and sacrifices. I owe a lot to my parents, who taught me about hard work and respect, about persistence and about how to be independent. My mother was a great role model of resilience, strength and character. I dedicate this Thesis, especially to my father, who I deeply miss and who is no longer with us, but I am sure that he was with me throughout the whole time, helping me along the way. I am also grateful to my brother who is always ready to help me for whatever I need. This last word of acknowledgment I have saved for my dear wife, who has supported me all these years and especially for giving birth to our wonderful twins who had made our lives even more enjoyable. 


\section{Spanish Acknowledgments}

La realización de esta tesis doctoral ha sido una experiencia que ha cambiado mi vida y que no habría sido posible sin el apoyo y la orientación que he recibido de muchas personas.

Ante todo, me gustaría expresar mi sincera gratitud a mis mentores, Dra. Maite Alguacil Marí y Dr. Celestino Suárez Burguet, por darme la oportunidad de embarcar en este extraordinario viaje. Estoy profundamente agradecido con ambos por su fundamental papel en este proyecto. Más que nada me gustaría darles las gracias por alentar mi investigación y permitirme crecer como investigador, por su continuo apoyo, paciencia, motivación y dirección a lo largo de este período. Me siento tremendamente honrado por la oportunidad de hacer completar mi programa doctoral bajo su dirección y habiendo aprendido tanto de ambos. No podría haber imaginado tener mejores mentores.

Me gustaría expresar mi más sincero agradecimiento a la Universitat Jaume I de Castellón, el Departamento de Economía y el Instituto de Economía Internacional por ofrecerme un ambiente ideal en el que me sentí libre y podía concentrarme en mi investigación. Me gustaría dar las gracias al proyecto Diseño de la Red de Plataformas Logísticas en España (RELOG) por ofrecerme apoyo financiero durante parte de mi doctorado. Les doy mi más sincero agradecimiento a todos ellos. Asimismo, les doy mi más sincero agradecimiento a todos mis amigos, tanto de España como de Macedonia.

Por último, pero no menos importante, estoy profundamente agradecido a mi familia por su amor, apoyo y sacrificios. Les debo mucho a mis padres, que me enseñaron el significado del trabajo duro, el respeto, la persistencia y cómo ser independiente. Mi madre ha sido siempre un gran modelo de resistencia, fuerza y carácter. Dedico esta tesis, especialmente a mi padre, a quien profundamente echo de menos y que ya no está con nosotros, pero estoy seguro que ha sido conmigo durante todo el tiempo y ayudándome a lo largo de este camino. También estoy agradecido a mi hermano que está siempre dispuesto a ayudarme. Esta última palabra de reconocimiento la guardo para mi querida esposa, que me ha apoyado todos estos años y sobre todo por dar a luz a nuestros maravillosos gemelos, quienes han hecho que nuestras vidas sean aún más agradables. 
Dedicated to my family and my mentors

- for your unconditional support, patience and sacrifices - 


\section{English Preface}

\section{General Framework of the economic transition in the Westem Balkan countries}

The region of the Western Balkans includes the countries of Albania, Bosnia and Herzegovina, Croatia, Macedonia, Montenegro, Serbia and Kosovo. The region is well known for its instability and recent history of wars and civil conflicts, but it is far less known for the changes that have taken place in the economic and social systems and the dynamic processes of transition and European integration that occurred over the last twenty years.

Similar to other transition economies in Europe, the modernization process in the Western Balkan countries (WBC) presented significant challenges. Nevertheless, the starting points of the WBC differed substantially, as these countries went through a series of devastating wars, sanctions and blockades, leaving the region with sizable destruction of physical capital and collapsed trade links. This made the transition process of the WBC significantly tougher compared to the Eastern European countries. Still, the WBC were able to initiate substantial structural reforms aimed at replacing their former planned economic systems with market economies and renewing trade integration both within the region and with the world, especially the European Union (EU). The WBC embarked on extensive reform programs that pursued aims such as liberalization, stabilization and privatization, started large infrastructure projects to rebuild their infrastructure and began building market based institutions. Since then, the Western Balkan countries have made impressive gains in rebuilding their war-torn economies and made significant increases in output and income.

Two important developments that marked the early process of transition and distinguished the WBC from the other communist countries in East Europe and the Soviet Union were the existence of private ownership and the privatization process of the so called social enterprises. The countries of the former Yugoslavia began their process of transition towards market economies in the 1980s, as reforms in the single country led 
to a unique economic system of market-socialism that permitted private ownership of small and medium businesses in parallel with the established system of administrative controls by the central government. Albania is an exception from this as the country was virtually functioning in an autarkic state till the early 1990s.

The second specific development in the region (at least for the countries of the former Yugoslavia) was the socially owned enterprises, which were different from the state owned enterprises that existed in the Soviet bloc. While this form of ownership was well suited for the former market- socialism system it proved to be an obstacle in the process of privatization that had far-reaching consequences in the years to come hampering corporate governance and incentives for restructuring. Namely, the conversion form social to private ownership proved difficult as there was no single owner from which the firm could be bought, rather the firm was basically owned by all of the workers. Different countries followed different privatization schemes and some were more successful than the others. For example, in FYR Macedonia, most socially-owned enterprises were sold to insiders rather than to strategic investors with capital and know-how, and many firms were thus left with substandard capital and management structure.

In the early years of the transition as prices were liberalized, inflation pressures picked-up fast and had devastating effects in the economies that had floating exchange rates and looser monetary policies. Most of the administrative prices in the socialist era were kept under cost coverage in order to keep the social peace and once these were liberalized inflation reached unprecedented levels. In Albania prices increased by more than 200 percent, while Serbia and Montenegro saw one of the worst hyperinflation of the century. The adopted floating exchange rates in these countries did not help the cause of keeping inflation under control. Other WBC in an attempt to ease these inflationary pressures and to keep the monetary policy under control adopted some form of fixed exchange rate regime. Bosnia and Herzegovina introduced a currency board while Macedonia had a peg to the deutschmark and later to the euro and Croatia had a tightly managed floating exchange rate. 
Continued conflicts and sanctions, as well as delayed transition in some countries had seriously disrupted once vital trade relation within the former Yugoslav republics and their participation in international production networks, leading to below-potential trade performance. To make matters worse the economic management of some countries was poor and there was widespread protectionism which hampered the development and performance of export-oriented industries.

Nonetheless, despite all this at the turn of the century the WBC had largely stabilized and were advancing fairly well through the transition process, especially in the areas of price liberalization, trade and foreign exchange and privatization. The challenge facing the WBC in the new millennium was to progress towards "second tier" reforms in upgrading institutions, improving the business environment, building infrastructure, and developing financing markets. Fortunately the WBC were able to advance along those lines and in that sense, a period of intense economic transformation, growth, and convergence took place.

During the decade of the 2000s the WBC started doing profound reforms that eliminated unnecessary regulations and hampered business development. Throughout the process several measures were taken such as, setting up one-stop-shops for starting a business and obtaining construction permits, improved investor protection, introduced or improved investment promotion laws, reduced non-tax fees, strengthened bankruptcy procedures, introduced or expanded the coverage of real estate cadasters, and set up entrepreneurial zones with good infrastructure and land free of ownership uncertainty. In addition, large infrastructure projects were started to improve the war-torn transport, energy and communication lines.

As it was the case all around the world, the WBC enjoyed a period of abundant global liquidity channeled through equity investment in their domestic banking systems facilitating lending activities. In fact, capital inflows into the region were as high as the ones that were directed towards the countries of Central Europe, leading to increased consumption and investment. Consequently, imports increased sharply disrupting the 
external balance and leading to widening current account deficits ${ }^{1}$. Some of the investments had been very efficient and actually led to increases in productivity; however some of them were directed into non-tradable sectors that had low productivity.

As economic growth strengthen and consumption improved, fiscal revenues also increased, despite cuts in tax rates in some countries in order to decrease the wage burden and increase competitiveness. Large scale privatization in some countries, like Macedonia, Montenegro and Kosovo also added extra revenues. This dynamics combined with the improvements in primary fiscal balances and forgiveness of part of the debt through the Paris club resulted in significant decline in the debt level in the region. As a result, governments in the region increased their appetite for spending, particularly on wages, pensions and large scale infrastructure projects, which proved to be unsustainable once the global crises hit in 2009.

Market reforms were accompanied by policy-induced trade integration, both with the EU and with neighboring countries, which significantly improved opportunities for export growth. Barriers to trade including non-tariff barriers were removed and customs systems and legal practices were aligned with those in the EU. The trade and transport facilitation program for South Eastern Europe helped customs reforms and improved coordination between border control agencies, as well as eliminating bottlenecks at border crossings in the region. At the same time as the Stabilization and Association Process was launched, the EU granted a comprehensive set of Autonomous Trade Preferences to the Western Balkan countries. These provided for a unilateral dismantling of import tariffs and duties for almost all goods emanating from the Western Balkan countries. In addition, regional cooperation was further enhanced with the extension of the Central European Free Trade Agreement (CEFTA) to the Western Balkans in December 2006 and the beginning of accession negotiations with the EU by most of the $\mathrm{WBC}^{2}$.

\footnotetext{
${ }^{1}$ In this period, Montenegro experienced one of the highest increases of the current account deficit in the World, reaching almost one half of its GDP.

${ }^{2}$ Out of the six countries, Croatia became a member of EU in July 2013; Serbia and Montenegro are in the accession negotiating process; Albania and Macedonia are in the status of EU candidate countries; while Bosnia and Herzegovina is considered a potential candidate country.
} 
As the transition process intensified and the regional and EU integration strengthened the WBC economies opened up to the world and became increasingly export oriented and integrated into the world economy. The exports ration with respect to GDP more than doubled, from 20 percent in 1996 to 42 percent in 2014, with some countries such as Serbia and Montenegro seeing a threefold increase in export shares. Export market destinations diversified, as the WBC became more competitive and penetrated new markets. In addition, the WBC managed to improve the quality of their exports by moving from mostly low-skill and technology-intensive products to medium- and highskill and technology-intensive products, especially in Croatia, Macedonia and Serbia. Moreover, the share of manufacturing goods in overall exports increased in all countries, especially in Macedonia and Serbia and Montenegro, allowing them to reinforce knowhow, productivity and output. The process of economic transition and the changing export structure are further elaborate in Chapter III of this Thesis.

The WBC also become more integrated into the production-sharing networks, especially within the European Union. This is evident by the increasing trade in parts and components in these countries which outpaced the rate of increase in final goods trade, with the former growing at more than twice the rate of the latter. The WBC had been active in buyer-driven production chains, but they are yet to make a significant transition toward producer driven supply chains. In the initial phases of the transition processing trade was largely concentrated in low-skill activities such as in clothing and furniture. However, as the transition process intensified there had been a positive structural shift towards relatively higher value-added industries like motor vehicles and machinery and mechanical appliances, especially in Macedonia and Serbia. Going forward, processing trade is likely to increase as the WBC have the potential to exploit new opportunities for the relocation and fragmentation of production, given that their location is at the heart of the transit corridor between the EU, Eastern Europe, Turkey and the Middle East. Chapter I and II discuss in more detail the evolution of processing trade in the WBC, looking at the determinants that are driving it as well as its effects on growth.

By 2008, the Western Balkan countries made impressive progress and reduced their gap in GDP per capita vis-à-vis advanced EU economies by 30 percent, riding the tide of 
deeper financial and trade integration, high capital inflows, rapid credit expansion and loosening fiscal policies. However, this pattern proved to be unsustainable, especially consumption linked to overheating credit growth, widening current account deficits and increasing private debt. As it was the case in most countries in the world, the boom period came to an end with the on-slot of the global financial crises. Foreign funding was pulled-back and capital flows to the WBC virtually dried out. This left the vast majority of banks in the region in shortage of capital, resulting in credit growth grounding to a hold or even turning negative in some countries. In addition, credit expansion registered in the years leading to the crises left companies with increased debt level which significantly affected their liquidity and capital adequacy. The current account deficits contracted by more than ten percentage point on average across the region. In short, growth across the region disappeared and remained lackluster in the years that followed, hampering income convergence with the rest of Europe.

This had serious consequences on the labor market which is one of the key structural challenges for the WBC and probably the area that saw the least improvement in the transition period. The WBC had been plagued with high unemployment and low rates of employment that persisted throughout the past two decade. Despite sizable reforms in the years leading-up to the global financial crises in 2009 labor market outcomes remained poor as average unemployment in the region remains above twenty percent, while average employment rates are around forty percent (more than ten percentage points lower than the EU).

To make matters worse, the slow growth and anemic labor market in some countries were coupled with an urgent need for fiscal consolidation. Higher revenue income registered in the pre-crisis period proved to be a result of cyclical factors, as they declined sharply. In addition, expenditure pressures coming from increases in pre-committed spending like wages and pensions made in the boom years, proved hard to scale back. This resulted in persistent and high fiscal deficits in all countries and led to rapidly increasing debt levels, especially in Albania, Croatia, Montenegro and Serbia, leaving the countries with no fiscal room for response to any possible adverse shocks in the future. 
These countries had made impressive progress in transforming their former centralized economies, but the ongoing crises had clearly showed that the transition process in the WBC has not been fully completed and remains a challenge for the future. Numerous reasons can be attributed to this. Difficult global economic and political environment, vested interests within the countries that had grown in power and sophistication, and discouragement with the way some reforms were executed are certainly some of them. In addition, the countries became increasingly reform fatigued, especially considering that the accession to the EU, which had been the main reform anchor, had become a distant prospect and had been dragging on for a long time.

Even though conditions across countries differ, a number of reforms, highlighted in this study, clearly stand out as priorities for the period to come. Improving the infrastructure connectivity is clearly one of them. Institutional reform and improved governance would also go a long way in boosting trade and growth. Finally, in line with findings presented in the next three chapters reforms that include the quality of governance, investment in education and human development as well as deepening of the financial markets and financial integration can certainly foster growth in the region.

\section{Purpose and aims of the research}

Since the brake-up of Yugoslavia in the early 1990s, the transition economies of the Western Balkan countries have been undergoing intense reforms and significant structural transformation resulting in a new export structure and an improvement in their economic performance. In this period they embarked on extensive reform programs that pursued aims such as liberalization, stabilization and privatization of the previously controlled sectors, tearing down regulations that burdened business development and building institutions that supported the market economy. In addition, the WBC economies increasingly opened-up to global trade and become ever more export oriented.

The general purpose of these measures was to build a business-friendly environment with minimal disruption to transport and communication between production segments leading to higher productivity and exports. This economic transformation resulted in a significant 
shift in the productive and export structure, allowing the WBC a chance to integrate into the pattern of international production networks (IPN) and to increase their productivity and growth. The objective of this work is to document this transformation, both in terms of identifying the key determinants that facilitate the participation of these economies in international production-sharing networks and their export specialization, as well as to measure the economic impact of this process.

Concretely, the main goals of this work are marked by three distinctive lines of analyzes. The first one looks at determinates that influence the participation of the WBC in international production networks. The second and the third line measure the impact of this structural transformation and increased participation in productive networks on growth in these economies.

More precisely the key contributions of this work are organized along the following lines:

a) To identify the nature and determinants of the factors which stimulate or deter the participation of the WBC in international production networks and processing trade.

b) To analyze the links between the increasing internationalization of production and the economic performance of the WBC

c) To contrast the effects of this processing trade to the ones steaming from final goods trade

d) To examine the effects of the increased sophistication of the productive structure of the WBC and its effects on growth

e) To determine the factors fostering the process of production sophistication

\section{Procedure and methodology used}

\subsection{Procedure: structure of the Thesis}

In order to address the aims that were set, the thesis is structured in three chapters as follow: 
In Chapter I we use data for parts and components trade in the WBC, as a proxy for the level of participation in international production networks and look at the factors that stimulate this process. In the study we look both at the imports and exports of parts and components trade, but we also compare this findings to final goods trade. This allows us to identify specific determinates that influence the participation in international production-sharing networks which might be different from the ones influencing final goods trade.

In Chapter II, we analyze the influence of the different degree of internationalization of production on the economic performance of the $\mathrm{WBC}$, by looking at their involvement in processing trade activities. We evaluate the country's position both as a source and a recipient of this kind of trade and also look at the importance of this kind of trade across sectors.

Finally, Chapter III analyzes the impact that the structural transformation and changing sophistication of production in the WBC has on their economic performance. In addition, we also look at what determines the factors fostering this process.

\subsection{Methodology used}

The empirical analysis in the Thesis makes use of the panel data approach. This methodology allows us to control for country-specific differences in technology, production and socioeconomic factors, thus avoiding the misspecification problems that individual heterogeneity involves ${ }^{3}$. Moreover, it is a well-known fact that panel data provide more degrees of freedom, less collinearity and therefore more efficiency.

In our econometric analyzes, for the sake of comparison and to test the robustness of our results, as well as to deal with the problem of reverse causality or simultaneity, we employ different specifications and estimation methods. In particular, we use Instrumental Variable (IV) techniques. In concrete, in order to control for the possibility that the different considered factors may be enhanced or correlated with the level of

\footnotetext{
${ }^{3}$ See Baltagi (2013) for a more detailed information about panel data models.
} 
participation in international production networks (in Chapter II), or might be enhanced by a higher sophistication of exports (in Chapter III) we employ the two-stage squares (TSLS) and GMM methodologies. Ignoring these effects might lead to the impact of these variables being overstated and to significant relationships being found where they do not in fact exist.

Additionally, to empirically test our hypothesis, in Chapter II and III we have developed two indexes: (i) the propensity index of international fragmentation and (ii) the export sophistication index, which had been used as the main regressors in the econometric analysis. More specifically, the former one is in fact a country-specific Balassa-type revealed comparative advantages index that captures the relative tendency of a country to participate in processing trade. In our analysis this index reveals the tendency of a country to participate in processing trade, using the average WBC level as a benchmark. Nevertheless, the index due to its nature of construction presents a biased range in terms of values higher than one expressing levels of fragmentation above the regional (WBC) average, whereas the opposite is true for values between one and zero. The nonsymmetric outcome of the results from the calculation introduces an evident difficulty when interpreting this index. We solve this methodological shortcoming by using a logarithmic conversion to the index and obtaining a symmetric range of values between one and minus one i.e. positive when the country has a comparative propensity to undertake processing trade and negative if the reverse is true, allowing us an easier interpretation of the index.

In Chapter III, in order to overcome the unavailability on product level research and development content of a product, as a measure of its sophistication level, we adopt the Hausmann et al. (2007) methodology and construct the index of export sophistication. This index is a measure of the sophistication of a country's export basket and it tries to capture the productivity level associated with a country's export basket. This measure is also considered a proxy of the most productive set of goods that a country can produce at a given time. The development of the index required a combination of trade and GDP per capita data of a consistent set of countries and products and involved more than one hundred thousand observations. 
Finally, one consistent shortcoming when carrying out the econometric analysis in all three chapters was data availability for different variables regarding the Western Balkan countries. Namely, there were numerous cases when data for all countries was not available for the required period, which forced us to make compromises and adjust the period or the scope of our analysis. Nevertheless, to the best of our knowledge we have managed to successfully overcome these obstacles and produce consistent sets of databases for all countries that allowed us to successfully perform the econometric analysis.

\section{Contributions}

The overarching contribution of this work relates to the deepening of the knowledge of the economies in Western Balkans, as one of the most under-researched parts of Europe, in economic terms. More specifically, the Thesis makes the following contributions to the literature, from which important policy advices can be drown:

a) First, we corroborate the theory that factor endowment differences and servicelink costs are the driving forces behind the fragmentation of the production process. In addition, we also find that these factors have a greater impact on trade in parts and components than on final goods trade.

b) Next, with the aim of analyzing the impact that the involvement in international production networks has on the economic performance of the WBC, following Baldone et al. (2007), we elaborate an index that captures the relative tendency of each country to participate in this process. The results show the positive influence of the increased participation in processing trade in these countries, but with some important differences across countries. Additionally, the effects of processing trade appear to be complementary the positive influence of traditional trade.

c) In this research we also look at the process of structural transformation and the sophistication of the production in the WBC. In doing so, we elaborate an export sophistication index, a la Hausmann et al. (2007). The analysis reveals that the structural transformation of the WBC from low to medium skill and technology manufactures has resulted in an increased level of export sophistication. This 
process seems to be largely driven by manufactured goods and in particular by medium-skill and technology goods and that it has a positive and significant effect on economic growth. However, we find that it is not the sophistication in highskill goods, but rather the increased sophistication in medium-skill and technology manufactured goods what is driving this process.

d) Finally, we examine the determinants fostering the process of increased sophistication of exports and conclude that both economic and financial development and a greater competition are critical factors to stimulate export sophistication in the WBC.

\section{Conclusions, final comments and policy implications}

The first chapter of the Thesis examines the determinants that drive the increasing globalization and integration of the WBC and the resulting process of international fragmentation of the production. Specifically, it looks at the factors that facilitate the participation of the WBC in international production-sharing networks, by looking at trade in parts and components. Using a gravity panel data model of disaggregated bilateral trade flows, we estimate gravity equations for the period 2000-2009. In this analysis not only parts and components imports are considered, but also two-way trade volumes between countries, meaning both imports and exports. In addition, we also do not consider only trade in parts and components, but de also contrast it to the more "traditional" trade in final goods in order to see if there are differences in the determinants that dive both processes.

Our findings show that annual growth in parts and components trade in the WBC is well above world growth during the period in question. In fact, the increase in parts and components imports and exports was more than two and three times the increase of this kind of trade at world level, respectively. Furthermore, the increase in WBC trade in parts and components was far greater than the increase in the EU countries. Moreover, this increase is even larger than the one experienced in final goods trade, pointing to the importance of this kind of trade for the region. 
According to the fragmentation literature, factor endowment differences and service-link costs are the driving forces behind the fragmentation of the production process. This theory is confirmed by our estimates, which show how factor endowment differences and market size significantly increase the fragmentation of production in this region, while distance deters it. We observe that the influence of distance, as part of the service-link costs that companies incur in order to engage in international production, in higher for part and components trade than for final goods trade, implying that the influence of distance-related costs on the IPN is greater due to the nature of the production process and multiple border crossings. Another determinant related to service-link costs is the quality of infrastructure. We find that infrastructure quality is extremely relevant in promoting parts and components trade. Furthermore, in view of the fact that there are more shipments between production segments within the IPN, infrastructure quality markedly favors parts and components trade when compared to final goods trade.

The degree of similarity in economic freedom and legal certainty in trading partner countries represents another key factor for parts and components trade in the region. Once again, the influence is much greater on parts and components trade than on final goods trade. Finally, our estimates confirm that, as predicted by the theory on international fragmentation, a reduction in the cost of trade associated with regional integration processes has favored the international division of production processes. We find that the regional ties between the republics of the former Yugoslavia are still very active, even after a decade of wars and conflicts. Once again the importance of these effects is higher for parts and components trade than for final goods trade.

Some important policy implications can be drown from this study. For example, firms that seek to lower their production costs through fragmentation should look to larger markets in the region, as market size determines the cost-efficiency of the service-link costs this process entails. But the importance of market size may also indicate that market-seeking decisions for locating some firms are also playing an important role. Improving the institutions to alleviate additional costs should be considered a priority strategy for policymakers. Governments should also recognize that developing quality infrastructure in the region is of vital importance to join the international division of labor 
and trade, as a higher quality of infrastructures promotes trade integration. Finally, they should be more aware of the high trade potential to be exploited from the intra-regional ties, especially in developing regional production networks.

In the second chapter, we go one step further and we test the hypothesis that trade created by international fragmentation of production may generate effects on economic growth beyond the beneficial influence of total or final goods trade. Given the availability of data, we focus on the period 2002-2013 and employ data on processing trade i.e. information about trade in goods that are exported or imported for reasons of processing. By looking both at inward and outward processing trade we are able to assess each country's relative position in the production chain both as a receiver and a source of processing trade, and also allows for assessing the importance of this kind of trade across sectors.

Our analysis clearly shows that the WBC are far more important destination of processing trade than a source of this kind of trade. In addition, processing trade plays an increasingly important role in the $\mathrm{WBC}$, especially in recent years when the value added of trade in these economies has increased significantly. We also, observe a positive structural shift towards relatively higher value-added industries.

Furthermore, our results reveal that greater participation in the international fragmentation of production exerts a beneficial influence on the economic behavior of the WBC, measured in terms of both differential and absolute GDP growth. The findings also sustain the hypothesis that the degree of involvement in international production networks positively influences the economic performance of the $\mathrm{WBC}$, even once the gains of total or final goods trade are considered. Thus, a higher degree of participation in IPN of the WBC gives them the possibility of achieving higher productivity and is a powerful contributor to growth, complementing the impacts generated by the total and final goods trade. Our results also show the importance of taking into account the role played by multinational firms in the WBC. The beneficial impact that the establishment of multinational firms has on economic growth is also verified by the sign and magnitude of our estimates. This outcome shows how relevant multinational firms' global strategies 
are for the trade pattern and economic activity of these countries. Finally, we also observe that capital accumulation has a significant and positive effect on the economic growth of these countries.

Overall, our findings support the idea that policies designed to promote the openness and participation of the WBC in the international division of production could be considered an important stimulus for the development and growth of these countries. The promotion of a certain type of economic policies may induce these countries to better exploit their comparative advantages improving so their likelihood of a successful economic modernization.

The last chapter of the Thesis looks at the process of structural transformation of the countries in the region and the changing sophistication of their exports. In particular, we seek to analyze the impact that this structural change has on the economic performance of the WBC and to determine the factors fostering this process. To do that, we elaborate an export sophistication index, a la Hausmann 2007. The index reflects the competitive peculiarities of the exported products on the basis of the degree of development of the exporting countries of each good and it is hence a proxy for the productivity of exports of a country. In our analysis we focus on the period 1996-2014. We consider the sophistication index on both aggregate level i.e. for all goods in the economy and for manufactured goods only. Furthermore, we disaggregate manufactured goods by the level of their skill and technology intensity, allowing us to look at the specific effects of different level of factor endowments of products.

Our findings show that the WBC had become increasingly export oriented and that this has been largely due to an increasing participation of the manufacturing sector in overall exports. We also observe that as a result of the structural transformation, production and exports of the WBC had become more sophisticated over the analyzed period. This process seems to be largely driven by manufactured goods and in particular by mediumskill and technology goods, indicating the WBC had been expanding their production frontier and acquiring new capabilities at this level of specialization. 
In line with previous empirical works, our results confirm the positive influence of export sophistication on real GDP per capita growth. Consequently, as expected, the improvement of the sophistication of the exports in a country will entail a subsequent growth in its income. Conversely, the share of highly technology-intensive manufactures in exports does not seem to influence significantly the economic performance of a country. However, when we look at the impact of medium-skill and technology intensive manufactures, our results show that they have a positive and significant influence from this kind of products. This ratifies our intuition that the observed movement from a specialization in low-skill and technology intensive product to a medium-skill and technology intensive product has significant consequences for economic growth in the WBC. Our analysis also confirms that there is a strong convergence effect towards the level of more developed countries. Finally, consistent to findings in chapter two we observe that investments and capital accumulation has a positive and significant effect on growth in these economies.

Another question that we analyze in this chapter refers to the main determinants behind the variation of the export sophistication. That is, what enables a country to improve the sophistication of its exports? The evidence obtained sustains that both economic and financial development are crucial factors in stimulating the sophistication of the export basket in the WBC. In addition, we also observe that a lower concentration in exports contributes to an increase in its sophistication and thus in economic growth.

Overall, our findings support the notion that structural reforms aimed at improving the production structure in the WBC have increased export sophistication in the region and can be considered an important stimulus for income growth. The promotion of policies specifically aimed at increasing sophistication in manufacturing products, and in particular to medium-skill and technology intensive products, have a significant potential to improve the future economic performance of these countries. 


\section{Future fines of research}

Finally, there are some promising future lines of research that can deepen the analysis even more.

First, it would be beneficial extending the analysis of the determinats that influence the participation of the WBC in international production networks. In that sense, while the results of this study are in line with the established fragmentation literature, we are aware that the determinants of the international fragmentation of production might differ from industry to industry depending on countries' patterns of specialization. Thus, a future avenue of research to draw more detailed policy implications could be to perform an indepth industry-by-industry analysis.

Second, looking at the effects on growth of the greater participation of the WBC in processing trade, our analysis confirmed that each country in the Western Balkans appears to have specialized in different industries gradually shifting towards industries with higher value-added. In that sense, further extension of this analysis should concentrate on a sectoral approach to this phenomenon especially considering that productive specialization logically implies different patterns of processing trade for specific sectors or products.

Finally, in terms of the observed structural transformation of the WBC it would be beneficial to know more about whether the relationship between export sophistication and growth in income per capita depends on the trade regime (processing or ordinary) and ownership type (domestic or foreign) of exporting firms. In addition, advancing in the design and construction of an import sophistication index (similar to the one already used for exported goods) might be useful in testing if growth is also affected by importing sophisticated inputs (or capital goods). 


\section{Spanish Preface}

\section{Marco general de la transición económica de los países de los Balcanes Occidentales}

La región de los Balcanes Occidentales incluye los países de Albania, Bosnia y Herzegovina, Croacia, Macedonia, Montenegro, Serbia y Kosovo. La región es conocida por su inestabilidad e historia reciente de guerras y conflictos civiles; sin embargo, es mucho menos destacada por los cambios económicos y sociales derivados de los procesos dinámicos de transición e integración europea producidos durante los últimos veinte años.

Al igual que en otras economías europeas en transición, la modernización en los países de los Balcanes occidentales (PBO) presentaba importantes desafíos. Sin embargo, el punto de partida de los $\mathrm{PBO}$ difería sustancialmente de las primeras, ya que estos últimos pasaron por una serie de guerras devastadoras, sanciones y bloqueos, que dejaron a la región con una destrucción considerable del capital físico, así como con los vínculos comerciales colapsados. Esto hizo que el proceso de transición del PBO resultase significativamente más difícil en comparación con los países de Europa del este. No obstante, los $\mathrm{PBO}$ fueron capaces de iniciar reformas estructurales importantes destinadas a sustituir sus antiguos sistemas económicos planificados por economías de mercado y reestablecer así la integración comercial, tanto dentro de la región como con el resto del mundo, en especial con la Unión Europea (UE). Los PBO se embarcaron en programas de profundas reformas que perseguían objetivos como son: la liberalización, la estabilización y la privatización, iniciando de esta forma grandes proyectos para reconstruir su infraestructura y estableciendo instituciones que permitieran soportar el mercado libre. Desde entonces, los países de los Balcanes occidentales han logrado avances importantes en la reconstrucción de sus economías devastadas por la guerra y han incrementado significativamente su producción e ingresos.

Dos importantes acontecimientos que marcaron el proceso inicial de la transición y distinguen los PBO de los otros países comunistas de Europa del Este y la Unión Soviética fueron la existencia de la propiedad privada y el proceso de privatización de las 
denominadas empresas sociales. Los países de la antigua Yugoslavia comenzaron su proceso de transición hacia una economía de mercado en la década de 1980; las reformas durante estos años condujeron a un sistema económico único de socialismo de mercado que permitió la propiedad privada de las pequeñas y medianas empresas en paralelo con el sistema establecido de controles administrativos por parte del gobierno central. Albania es una excepción dado que el país estaba prácticamente funcionando en un estado autárquico hasta el principio de los años noventa del siglo pasado.

El segundo proceso específico de la región (al menos para los países de la antigua Yugoslavia) fue la presencia de las empresas de propiedad social, diferentes de las empresas estatales que existían en el bloque soviético. Si bien esta forma de propiedad era muy adecuada para el antiguo sistema de socialismo de mercado, resultó ser un obstáculo en el proceso de privatización que tuvo consecuencias a largo plazo al dificultar la gestión empresarial y los incentivos para la reestructuración. Es decir, la forma de cambiar de propiedad social a propiedad privada se complicaba ya que no había un sólo dueño de la empresa a quien pudiera ser comprada, sino que la empresa era básicamente propiedad de todos los trabajadores. Diferentes países siguieron diferentes modelos de privatización y algunos tuvieron más éxito que otros. Por ejemplo, en la ARY de Macedonia, las empresas se vendieron a la gente de dentro de las empresas, en lugar de a inversores estratégicos con capital y conocimientos técnicos; de esta forma, muchas empresas se quedaron con una estructura de capital y gestión deficiente.

En los primeros años de la transición, con la liberalización de los precios surgieron presiones inflacionistas que tuvieron efectos devastadores sobre las economías con tipos de cambio flotantes y políticas monetarias más laxas. Durante la era socialista, la mayoría de los precios administrativos se mantuvieron por debajo de los costes con el fin de mantener la paz social, pero una vez que éstos se liberalizaron la inflación alcanzó niveles sin precedentes. En Albania, por ejemplo, los precios se incrementaron en más de un 200 por ciento, mientras que Serbia y Montenegro sufrieron una de las peores hiperinflaciones del siglo. Los tipos de cambio flotantes adoptadas en estos países no ayudaron a mantener la inflación bajo control. Otros PBO, en un intento de aliviar estas presiones inflacionistas y mantener una política monetaria estable, adoptaron algún 
régimen de tipo de cambio fijo. Bosnia y Herzegovina introdujeron una caja de conversión, mientras que Macedonia mantuvo una paridad con el marco alemán y más tarde con el euro, y Croacia estableció un tipo de cambio flotante estrictamente controlado.

Los continuos conflictos y sanciones, así como el retraso en la transición de algunos países perturbaron gravemente las relaciones comerciales, tan vitales dentro de las repúblicas de la antigua Yugoslavia, y su participación en redes internacionales de producción, lo que resultó en un nivel de comercio por debajo del potencial. Para empeorar las cosas, la gestión económica de algunos países fue pobre y existía además un proteccionismo generalizado, lo que dificultó el desarrollo y el funcionamiento de las industrias orientadas a la exportación.

No obstante, a pesar de estas dificultades, con el comienzo del nuevo siglo los PBO se habían estabilizado en gran parte y avanzaban considerablemente en su transición, sobre todo en los ámbitos de liberalización de precios, comercio y privatización. Con el nuevo mileno, los PBO se enfrentaban al desafío de avanzar en las reformas "de segundo nivel" incluyendo la modernización de las instituciones, mejora del entorno empresarial, construcción de infraestructuras, y desarrollo de los mercados financieros. Afortunadamente, los PBO fueron capaces de alcanzar importantes mejoras en ese sentido, lo que llevó a un período de intensa transformación económica, crecimiento y convergencia.

Durante la primera década del 2000, los PBO iniciaron profundas reformas eliminando regulaciones innecesarias que dificultaban el desarrollo de los negocios. En este periodo, se tomaron medidas tales como, la creación de una ventanilla única para iniciar un negocio u obtener permisos de construcción, mejoras en la protección de los inversores, introducción de leyes de promoción de inversiones, reducción de las tasas no tributarias, formalización de los procedimientos de quiebra, introducción o ampliación de la cobertura de los catastros inmobiliarios y establecimiento de zonas empresariales con buena infraestructura y suelos de propiedad libres de incertidumbres. Además, se 
iniciaron grandes proyectos de infraestructura para mejorar los transportes, la energía y las líneas de comunicación arruinadas por las guerras.

Al igual que en el resto del mundo, los PBO disfrutaron de un período de abundante liquidez mundial que se canalizó a la inversión de capital a través de sus sistemas bancarios nacionales que facilitaron el crédito. De hecho, los flujos de capital hacia esta región fueron tan elevados como los destinados a los países de Europa central, dando lugar a un incremento del consumo y la inversión. En consecuencia, las importaciones aumentaron considerablemente perturbando el equilibrio externo con un aumento de los déficits por cuenta corriente. Algunas de las inversiones fueron muy eficientes y ayudaron a incrementar la productividad; sin embargo, otras fueron dirigidas hacia los sectores no-comercializables con una baja productividad.

A medida que el crecimiento económico se fortalecía y mejoraba el consumo, los ingresos fiscales también aumentaron, a pesar de los recortes en los tipos impositivos de algunos países que buscaban aliviar la carga salarial y aumentar la competitividad. La privatización a gran escala en algunos países, como Macedonia, Montenegro y Kosovo también agregó ingresos adicionales. Esta dinámica, combinada con las mejoras en los balances fiscales primarios y la quita de parte de la deuda a través del club de París, dio lugar a una disminución significativa en el nivel de deuda en la región. Como consecuencia, los gobiernos de la región aumentaron su apetito por el gasto, sobre todo en salarios, pensiones y grandes proyectos de infraestructura, que resultó ser insostenible una vez que la crisis global golpeó la región en 2009.

Las reformas de mercado fueron acompañadas por una integración comercial, inducida políticamente, tanto con la UE como con los países vecinos, lo que mejoró significativamente las oportunidades de crecimiento de las exportaciones. Se eliminaron las barreras al comercio, incluidas las barreras no arancelarias, y se alinearon los sistemas aduaneros y prácticas jurídicas con los de la UE. El programa de facilitación del comercio y el transporte para Europa Sudoriental llevó a reformas aduaneras y a la mejora de la coordinación entre los organismos de control fronterizo, ayudando a la eliminación de los cuellos de botella en las fronteras en los pasos de la región. Al mismo 
tiempo que se puso en marcha el Proceso de Estabilización y Asociación, la UE concedió un amplio conjunto de preferencias comerciales autónomas a los países de los Balcanes occidentales. Esto proporcionó un desmantelamiento unilateral de los aranceles de importación y obligaciones para casi todos los productos procedentes de los países de los Balcanes occidentales. Además, la cooperación regional se ha mejorado aún más con la prórroga del Acuerdo Centroeuropeo de Libre Comercio (CEFTA) a los Balcanes occidentales en diciembre de 2006 y el comienzo de las negociaciones de adhesión a la UE por la mayor parte de los PBO.

A medida que el proceso de transición se intensificó y se reforzó la integración regional y con la UE, las economías de los PBO se abrieron al mundo orientándose cada vez más a las exportaciones y hacia una integración con la economía mundial. La proporción de las exportaciones con respecto al PIB ha incrementado más del doble, concretamente del 20 por ciento en 1996 al 42 por ciento en 2014. Algunos países, como Serbia y Montenegro han visto incluso triplicar sus cuotas de exportación. Los mercados de destino de exportaciones se han diversificado, ya que los PBO han incrementado su competitividad y penetrado en nuevos mercados. Además, los PBO han logrado mejorar la calidad de sus exportaciones al pasar de exportar mayoritariamente productos con bajo nivel de conocimientos y contenido tecnológico a productos con medio y alto nivel de conocimientos y contenido tecnológico, sobre todo en Croacia, Macedonia y Serbia. Por otra parte, la proporción de productos manufacturados con respeto a las exportaciones totales ha aumentado en todos los países, especialmente en Macedonia y Serbia y Montenegro, lo que les ha permitido reforzar los conocimientos técnicos, la productividad y la producción. El proceso de transición económica y el cambio en la estructura de las exportaciones se analiza con más detalle en el Capítulo 3 de esta Tesis.

Los PBO se han ido integrando cada vez más en las redes de producción internacionales, especialmente dentro de la Unión Europea. Hecho evidente por el creciente peso del comercio de partes y componentes en estos países, que ha llegado a superar a la tasa de aumento del comercio de bienes finales, con el primero creciendo a un ritmo más del doble de la tasa del último. Los PBO han participado activamente en las cadenas productivas dirigidas por el comprador. Sin embargo, todavía queda hacer una transición 
significativa hacia cadenas de suministros impulsadas por los productores. En las fases iniciales de la transición, el comercio de procesamiento fue en gran parte concentrado en actividades de baja cualificación, como ropa y muebles. Sin embargo, conforme el proceso de transición se intensificó se produjo un cambio estructural positivo hacia las industrias de valor añadido relativamente más altos, como vehículos, maquinaria y aparatos mecánicos, especialmente en Macedonia y Serbia. De cara al futuro, es probable que aumente el comercio de procesamiento en la región, en la medida en que los PBO tienen todavía potencial para explotar nuevas oportunidades de relocalización y fragmentación del proceso productivo, dada su estratégica localización en el corazón del corredor de tránsito entre la Unión Europea, Europa del Este, Turquía y Oriente Este. Los capítulos 1 y 2 discuten con más detalle la evolución del comercio de procesamiento en los $\mathrm{PBO}$, centrándose en los determinantes que impulsan el proceso, así como en sus efectos sobre el crecimiento.

En los años previos al 2008, los países de los Balcanes occidentales realizaron progresos impresionantes y redujeron su brecha del PIB per cápita vis-à-vis con las economías avanzadas de la UE en un 30 por ciento, montándose al carro de una mayor integración financiera y comercial, flujos de capital elevados, rápida expansión del crédito y aflojamiento de las políticas fiscales. Sin embargo, este modelo de crecimiento resultó ser insostenible, sobre todo el consumo vinculado a un sobrecalentamiento del crecimiento del crédito, llevando a aumentos del déficit por cuenta corriente y de la deuda privada. Como en el caso de la mayoría de países del mundo, el período de auge llegó a su fin con la irrupción de la crisis financiera global. La financiación externa y los flujos de capital a los PBO prácticamente se agotaron. Esto dejó a la gran mayoría de los bancos de la región en escasez de capital, lo que resultó en el estancamiento del crecimiento del crédito e incluso con tasas negativas en algunos países. Además, la expansión del crédito registrado en los años previos a la crisis dejó a las empresas con un importante nivel de deuda, lo que afectó significativamente a su liquidez y suficiencia de capital. Los déficits por cuenta corriente disminuyeron en más de diez puntos porcentuales en promedio en toda la región. En resumen, el crecimiento desapareció en toda la región quedándose sin aliento en los años que siguieron a la crisis, lo que dificultó la convergencia en términos de ingresos con el resto de Europa. 
Todo ello tuvo graves consecuencias en el mercado laboral, siendo uno de los retos estructurales clave para los PBO y probablemente el área que vio menos mejoras en el período de transición. Los PBO han sufrido de altas tasas de desempleo y bajas tasas de empleo que han persistido a lo largo de las últimas dos décadas. A pesar de las importantes reformas de los años previos a la crisis financiera de 2009, los resultados en el mercado laboral siguen siendo pobres, con la media de desempleo en la región manteniéndose por encima del veinte por ciento, mientras que las tasas promedias de empleo son alrededor de cuarenta por ciento (más de diez puntos porcentuales por debajo de la UE).

Para empeorar aún más las cosas, el lento crecimiento y el mercado laboral anémico en algunos países se unió a una necesidad urgente de consolidación fiscal. Los altos ingresos fiscales registrados en el período anterior a la crisis resultaron ser consecuencia de factores cíclicos, ya que se redujeron drásticamente tras la crisis. Además, las presiones de gasto procedentes de incrementos en gastos pre-comprometidos, como los salarios y las pensiones, realizados en los años del boom, resultaron difíciles de bajar. Esto dio lugar a déficits fiscales altos y persistentes en todos los países y llevó a aumentar rápidamente los niveles de deuda, especialmente en Albania, Croacia, Montenegro y Serbia, dejando a los países sin un margen fiscal para responder a posibles choques negativos en el futuro.

Si bien estos países han hecho progresos importantes en la transformación de sus antiguas economías centralizadas, la crisis actual ha demostrado claramente que el proceso de transición en los $\mathrm{PBO}$ no se ha completado y sigue siendo un reto para el futuro. Numerosas razones pueden atribuirse a esto. El difícil entorno económico y político mundial, los intereses opacos creados dentro de los países que habían crecido en el poder y la sofisticación, y el desánimo por la forma de ejecutar algunas reformas son sin duda algunos de ellos. Además, los países se hicieron cada vez más pesimistas a las reformas, sobre todo teniendo en cuenta que la adhesión a la UE, que había sido el ancla principal de las reformas, se había convertido en una perspectiva lejana y se alargó durante mucho tiempo. 
A pesar de que las condiciones de los distintos países difieren, una serie de reformas, subrayadas en este estudio, se destacan claramente como prioridades para el período por venir. La mejora de la infraestructura de conectividad es claramente una de ellas. La reforma institucional y la mejora de la gobernanza también contribuirían en gran medida al fomento del comercio y al crecimiento. Finalmente, en línea con los resultados presentados en los próximos tres capítulos, cambios relacionados con la calidad del gobierno, la inversión en la educación y el desarrollo humano, así como la profundización de los mercados financieros y la integración financiera pueden sin duda fomentar el crecimiento en la región.

\section{Propósito y objetivo de la investigación}

Desde la ruptura de la antigua Yugoslavia, a principios de los 1990, las economías en transición de los países de los Balcanes occidentales han experimentado reformas intensas y una transformación estructural significativa que ha resultado en un nuevo patrón de las exportaciones y en una mejora de sus resultados económicos. En este período, los $\mathrm{PBO}$ se embarcaron en programas de reformas amplias que persiguieron objetivos tales como la liberalización, la estabilización y la privatización de los sectores anteriormente controlados, eliminando regulaciones que dificultaban el desarrollo empresarial y construyendo instituciones que apoyaban a la economía de mercado. Además, los $\mathrm{PBO}$ se han ido abriendo cada vez más al comercio mundial, volviéndose progresivamente más orientadas a la exportación.

El objetivo general de estas medidas fue la de construir un entorno de negocios, con una interrupción mínima al transporte y a la comunicación entre los segmentos de producción que lleven a una mayor productividad y de las exportaciones. Esta transformación económica dio lugar a un cambio significativo en la estructura productiva y de exportación, lo que permitió a los PBO integrarse en la estructura de las redes de producción internacional y aumentar su productividad y crecimiento. El objetivo de este trabajo es analizar esta transformación, tanto en términos de la identificación de los determinantes clave que faciliten la participación de estas economías en las redes de 
producción internacional y su especialización exportadora, como en el estudio del impacto económico de este proceso.

En concreto, los objetivos principales de este trabajo están marcados en tres líneas distintivas de análisis. La primera se centra en los determinantes de la participación de los PBO en las redes internacionales de producción. La segunda y la tercera línea de investigan el impacto que esta transformación estructural y el aumento de la participación en redes productivas tiene sobre el crecimiento económico de esas economías.

Más concretamente, las principales contribuciones de este trabajo hacen referencia a las siguientes cuestiones:

a) Identificar la naturaleza de los factores que estimulan o dificultan la participación de los PBO en las redes internacionales de producción y el comercio de procesamiento.

b) Analizar los vínculos entre la creciente internacionalización de la producción y el rendimiento económico de los $\mathrm{PBO}$.

c) Contrastar los efectos del comercio de bienes de procesamiento en comparación con los del comercio de bienes finales.

d) Examinar el impacto que la creciente sofisticación de la estructura productiva de los países de los Balcanes occidentales tiene sobre su crecimiento.

e) Determinar los factores que fomentan el proceso de sofisticación de la producción en estos países.

\section{Procedimiento y metodología utilizada}

\subsection{Procedimiento: estructura de la Tesis}

Con el fin de lograr los objetivos mencionados, la tesis se ha estructurado en tres capítulos: 
En el Capítulo I, se utilizan datos de comercio en partes y componentes de los PBO como una aproximación al nivel de participación de estos países en las redes internacionales de producción, y se estudian los factores que estimulan este proceso. En este estudio, analizamos las importaciones y exportaciones de partes y componentes, pero también comparamos estos flujos con del comercio de bienes finales. Esto nos permite identificar los determinantes específicos que influyen en la participación de los PBO en las redes internacionales de producción, así como comparar éstos con los factores que determinan el comercio de bienes finales.

En el Capítulo II, se analiza el efecto que los distintos niveles de participación en la internacionalización de la producción tienen sobre el rendimiento económico de los PBO, a través de su participación en el comercio de procesamiento. Evaluamos la posición relativa del país tanto como fuente, como como receptor de este tipo de comercio, así como la importancia del comercio de procesamiento por sectores.

Por último, en el Capítulo III se analiza el impacto que la transformación estructural y el cambio de la sofisticación de la producción en los PBO tienen sobre su crecimiento económico. Asimismo, se estudian los factores subyacentes a este proceso.

\subsection{Metodología empleada}

El análisis empírico de la Tesis hace uso del enfoque de datos de panel. Esta metodología nos permite controlar las diferencias específicas de cada país en tecnología, producción y factores socioeconómicos, evitando así los problemas de mala especificación que la heterogeneidad individual implica. Por otra parte, es un hecho bien conocido que los datos de panel proporcionan más grados de libertad, menos colinealidad y por tanto una mayor eficiencia.

Con el fin de comparar resultados y probar la solidez de los mismos, así como para hacer frente al problema de la causalidad inversa o simultaneidad, en nuestro análisis econométrico hemos empleado diferentes especificaciones y diversos métodos de estimación. En particular, hemos utilizado técnicas de variables instrumentales. Concretamente, para controlar la posibilidad de que los distintos factores explicativos 
considerados puedan reforzarse o estar correlacionados con el nivel de participación en las redes internacionales de producción (en el Capítulo II), o con una mayor sofisticación de las exportaciones (en el Capítulo III) hemos recurrido a los mínimos cuadrados en dos etapas y a la metodología GMM. Ignorar estos efectos podría llevarnos a sobreestimar el impacto de estas variables y a encontrar relaciones significativas donde en realidad no existen.

Además, para probar empíricamente nuestras hipótesis, en el Capítulo II y III hemos calculado dos índices: (i) el índice de propensión de fragmentación internacional y (ii) el índice de sofisticación de las exportaciones, los cuales han sido utilizados como determinantes principales en los modelos econométricos. Más específicamente, el índice de propensión de fragmentación internacional es de hecho un índice tipo Balassa de ventajas comparativas que capta la tendencia relativa de un país a participar en el comercio de procesamiento. En nuestro análisis, este índice revela la tendencia de un país a participar en el comercio de procesamiento, utilizando el nivel promedio de los PBO como punto de referencia. Sin embargo, por propia definición, este índice presenta un sesgo, en el sentido en que los valores superiores a la unidad expresan niveles de la fragmentación por encima de la media regional, mientras que lo contrario es cierto para los valores entre uno y cero. La ausencia de simetría por consiguiente introduce una dificultad evidente a la hora de interpretar el índice. Nosotros tratamos de resolver esta deficiencia metodológica mediante el uso de una conversión logarítmica del índice. De esta forma, obtenemos una serie simétrica de valores entre uno y menos uno; el índice es positivo cuando el país tiene una propensión comparativa a llevar a cabo comercio de procesamiento y negativo si ocurre lo contrario, lo que nos permite una interpretación más fácil del índice.

En el Capítulo III, dada la ausencia de datos en I+D a nivel de productos como medida de su nivel de sofisticación, adoptamos la metodología de Hausmann et al. (2007) elaborando un índice de sofisticación de las exportaciones. Este índice trata de medir la sofisticación de la cesta de exportación de un país a través del nivel de productividad asociada a dicha cesta. Esta medida también se considera una aproximación o proxy del conjunto de los bienes más productivos que un país puede producir en un momento dado. 
El cálculo de este índice ha requerido la utilización conjunta de datos de comercio y de PIB per cápita de un amplio grupo de países y productos involucrando a más de cien mil observaciones.

Por último, una dificultad común en el análisis econométrico de los tres capítulos ha sido la falta de disponibilidad de datos para las diferentes variables con respecto a los países de los Balcanes occidentales. En este sentido, ha habido numerosos ocasiones en que los datos de todos los países no estaban disponibles para el período requerido, lo que nos ha obligada a hacer concesiones y ajustar el período o el alcance de nuestro análisis. Sin embargo, desde nuestro punto de vista, hemos logrado superar con éxito estos obstáculos y producir conjuntos de bases de datos consistentes para todos los países lo que nos ha permitido realizar con éxito el análisis econométrico.

\section{Aportes}

La contribución principal de este trabajo hace referencia a una profundización de los conocimientos de las economías de los Balcanes Occidentales, como una de las partes más sub-investigadas de Europa. Más específicamente, la Tesis hace las siguientes aportaciones a la literatura, de las que se derivan importantes recomendaciones de política económica:

a) En primer lugar, corroboramos la teoría de que las diferencias en la dotación de factores y los costes de transacción impulsan la fragmentación del proceso de producción. Además, encontramos también que estos factores tienen un mayor impacto sobre el comercio de partes y componentes que en el comercio de bienes finales.

b) A continuación, con el objetivo de analizar el impacto que la participación en redes internacionales de producción tiene sobre el crecimiento económico de los PBO, siguiendo a Baldone et al. (2007), elaboramos un índice que recoge la tendencia relativa de cada país a participar en este proceso. Los resultados muestran la influencia positiva que una mayor participación en el comercio de procesamiento tiene sobre el crecimiento de estos países, si bien encontramos algunas diferencias importantes entre los países. 
Además, los efectos beneficiosos del comercio de procesamiento parecen complementar a la influencia positiva del comercio tradicional.

c) En esta investigación también nos fijamos en el proceso de transformación estructural y, más concretamente, en la sofisticación de la producción de los PBO. Para ello, elaboramos un índice de sofisticación de las exportaciones, a la Hausmann et al. (2007). El análisis revela que la transformación de la estructura productiva de los PBO desde productos con un bajo contenido en conocimiento y nivel tecnológico hacia productos con un conocimiento y nivel tecnológico medio se ha traducido en un aumento en el nivel de sofisticación de las exportaciones. Este proceso parece además estar impulsado en gran medida por los productos manufacturados y en particular por productos con un nivel tecnológico medio, que tienen un efecto positivo y significativo en el crecimiento económico. Observamos que más que un crecimiento en la sofisticación de los bienes con alto nivel tecnológico, ha sido el aumento de la sofisticación en productos manufacturados con nivel tecnológico medio los que han impulsado ese proceso.

d) Por último, examinamos cuáles son los determinantes que fomentan el proceso de aumento de la sofisticación de las exportaciones y concluimos que el desarrollo económico y financiero y una mayor competencia en el mercado son factores críticos para estimular la sofisticación de las exportaciones en los PBO.

\section{Conclusiones, comentarios finales e implicaciones política}

El primer capítulo de la tesis analiza los determinantes que impulsan la creciente globalización e integración de los PBO y el resultante proceso de fragmentación internacional de la producción. En concreto, se analizan los factores que facilitan la participación de los $\mathrm{PBO}$ en las redes internacionales de producción, centrándonos en el comercio de partes y componentes. Utilizando un modelo de datos de panel con flujos bilaterales de comercio, estimamos ecuaciones de gravedad para el período 2000-2009.

En este análisis se consideran no sólo las importaciones de partes y componentes, sino también el comercio bilateral entre los países, es decir, tanto las importaciones como las exportaciones. Se estudia también los factores del comercio más "tradicional" de bienes 
finales con el fin de ver si hay diferencias en los determinantes que conducen a ambos procesos de internacionalización.

Nuestros resultados muestran que el comercio de partes y componentes en los PBO crece muy por encima del comercio mundial de estos bienes durante el período en cuestión. De hecho, el aumento de las importaciones y exportaciones de partes y componentes fue de más de dos y tres veces el aumento de este tipo de comercio a nivel mundial. Por otra parte, el aumento del comercio de los PBO de partes y componentes fue mucho mayor que el crecimiento observado en el comercio de estos bienes en los países de la UE. Asimismo, el crecimiento de este tipo de comercio es aún mayor que el aumento en el comercio de bienes finales, lo que destaca la importancia de este tipo de comercio para la región.

De acuerdo con la literatura sobre la fragmentación del proceso productivo, las diferencias en la dotación de factores y en los costes de transacción son las fuerzas que impulsan la fragmentación de la producción. Nuestras estimaciones corroboran esta teoría, al mostrar cómo las diferencias en la dotación de factores y el tamaño del mercado aumentan significativamente la fragmentación de la producción en esta región, mientras que la distancia la dificulta. Observamos que la de la distancia, como parte de los costes de transacción, tienen in impacto negativo mayor sobre el comercio de partes y componentes que sobre el comercio de bienes finales, lo que implica que la influencia de los costes relacionados con la distancia es mayor en las redes de producción debido a la naturaleza del proceso de producción y a los múltiples cruces de fronteras. Otro factor determinante en relación con los costes de transacción es la calidad de la infraestructura. Encontramos que la calidad de la infraestructura es muy relevante para el estímulo del comercio de partes y componentes. Además, dado el hecho de que hay más envíos entre los segmentos de producción dentro de las redes internacionales de producción, la calidad de la infraestructura favorece notablemente más el comercio de partes y componentes que al comercio de bienes finales.

El grado de similitud en términos jurídicos y apertura económica con los países socios representa otro factor clave para el comercio de partes y componentes en la región. De 
nuevo, la influencia de este factor es mucho mayor en el comercio de partes y componentes que en el comercio de bienes finales. Por último, nuestras estimaciones confirman que, de acuerdo con la teoría de la fragmentación internacional de la producción, una reducción en el coste del comercio asociado a los procesos de integración regional favorece la división internacional de los procesos productivos. Encontramos que los lazos regionales entre las repúblicas de la ex-Yugoslavia siguen siendo muy activos, incluso después de una década de guerras y conflictos. Una vez más la importancia de estos efectos es mayor para el comercio de partes y componentes que para el comercio de bienes finales.

De este estudio se deducen algunas implicaciones importantes de política económica. Por ejemplo, las empresas que buscan reducir sus costos de producción a través de la fragmentación de su proceso productivo debería prestar atención a los mercados más grandes de la región, en tanto y cuanto el tamaño del mercado determina la eficiencia en los costes de transacción que este proceso conlleva. La importancia del tamaño del mercado podría indicar también que detrás de las decisiones de localización de algunas empresas la búsqueda de mercados desempeña un importante papel. Asimismo, una mejora en las instituciones, que permita disminuir costes adicionales, debe considerarse una estrategia prioritaria para las autoridades. Los gobiernos también deben reconocer que el desarrollo de una infraestructura de calidad en la región es de vital importancia para unirse a la división internacional del trabajo y el comercio, en la medida que una mayor calidad de las infraestructuras promueve la integración comercial. Por último, las autoridades deben ser conscientes del alto potencial comercial subyacente de los vínculos intra-regionales, especialmente en el desarrollo de redes regionales de producción.

En el segundo capítulo, damos un paso más, contrastando la hipótesis de que el comercio derivado de la fragmentación internacional de la producción puede generar efectos sobre el crecimiento económico que van más allá de la influencia beneficiosa del comercio total o de bienes finales. Dada la disponibilidad de los datos, nos centramos en el período que va desde 2002 hasta 2013. En este análisis, empleamos datos sobre el comercio de procesamiento; es decir, información sobre el comercio de bienes que se exportan o importan por razones de procesamiento. Además, al observar tanto el comercio de 
procesamiento en importaciones como en exportaciones podemos evaluar la posición relativa de cada país en la cadena de producción, tanto como receptor o fuente de comercio de procesamiento, lo que nos permite asimismo evaluar la importancia de este tipo de comercio en todos los sectores industriales.

Nuestro análisis muestra que los PBO son claramente más un destino del comercio de procesamiento que un fuente del mismo. Además, el comercio de procesamiento desempeña un papel cada vez más importante en los PBO, especialmente en los últimos años cuando el valor añadido del comercio de estas economías se incrementa significativamente. También, observamos un cambio estructural positivo hacia industrias de mayor valor añadido.

Además, nuestros resultados revelan que una mayor participación en la fragmentación internacional de la producción ejerce una influencia beneficiosa sobre el comportamiento económico de los $\mathrm{PBO}$, medido tanto en términos de diferencial del crecimiento, como en crecimiento absoluto del PIB. Los resultados también sustentan la hipótesis de que el grado de participación en las redes internacionales de producción influye positivamente en los resultados económicos de los $\mathrm{PBO}$, incluso una vez considerada las ganancias del comercio total o definitivo de bienes. Por lo tanto, una mayor participación en las redes internacionales de producción de los PBO, da a estas economías la posibilidad de conseguir una mayor productividad, siendo un importante determinante del crecimiento, complementando así el impacto beneficioso generado por el comercio total y bienes finales. Asimismo, nuestros resultados muestran la importancia de considerar el papel de las empresas multinacionales en el comportamiento económico de los $\mathrm{PBO}$. El impacto beneficioso que el establecimiento de empresas multinacionales tiene en el crecimiento económico se verifica por el signo y la magnitud de nuestras estimaciones. Este resultado muestra la importancia que las estrategias globales de las empresas multinacionales tienen para el patrón del comercio y la actividad económica de estos países. Por último, también observamos que la acumulación de capital tiene una influencia significativa y positiva sobre el crecimiento económico de estos países. 
En general, nuestros resultados apoyan la idea de que las políticas destinadas a promover la apertura y la participación de los $\mathrm{PBO}$ en la división internacional de la producción podrían ser consideradas un importante estímulo para el desarrollo y crecimiento de estos países. La promoción de un determinado tipo de políticas económicas puede inducir a estos países a explotar mejor sus ventajas comparativas mejorando así sus posibilidades para una modernización económica exitosa.

El último capítulo de la Tesis analiza el proceso de transformación de la estructura productiva de los países de la región y la sofisticación de sus exportaciones. En particular, analizamos el impacto que este cambio estructural tiene en el rendimiento económico de los PBO y tratamos de determinar los factores que fomentan este proceso. Para ello, elaboramos un índice de sofisticación de las exportaciones, a la Hausmann 2007. El índice refleja la competitividad relativa de los productos exportados, en función del grado de desarrollo de los países exportadores de cada bien. Es, por lo tanto, un indicador de la productividad de las exportaciones de un país. En nuestro análisis nos centramos en el período de 1996 a 2014. Consideramos el índice de sofisticación tanto a nivel agregado, es decir, para todos los bienes de la economía, como sólo para productos manufacturados. Asimismo, desagregamos los productos manufacturados por su nivel de intensidad en términos de conocimiento y tecnología, lo que nos permite examinar los efectos específicos niveles diferentes de dotación factorial

Nuestros resultados muestran que los PBO se han vuelto cada vez más orientados a la exportación y que esto se ha debido en gran parte a una creciente participación del sector manufacturero en las exportaciones totales. Observamos también que, como resultado de la transformación estructural, la sofisticación de producción y las exportaciones de los PBO se ha incrementado durante el período analizado. Este proceso parece estar impulsado en gran medida por los productos manufacturados y en particular por productos con contenido tecnológico medio, lo que indica que los PBO habrían expandido su frontera de producción adquiriendo nuevas capacidades en este nivel de especialización. 
En línea con los trabajos empíricos anteriores, nuestros resultados confirman la influencia positiva de una mayor sofisticación de las exportaciones sobre el crecimiento del PIB per cápita. En consecuencia, tal y como se espera, la mejora de la sofisticación de las exportaciones de un país implicaría un crecimiento posterior de sus ingresos. Por el contrario, la proporción de manufacturas altamente intensivas en tecnología en las exportaciones no parece haber influido significativamente en el crecimiento económico de estos países. Por el contrario, cuando nos centramos en el impacto que la sofisticación de manufacturas contenido tecnológico medio, nuestros resultados muestran que ésta tiene una influencia positiva y significativa sobre el crecimiento. Esto ratifica nuestra idea de que el movimiento observado desde una especialización en productos con contenido tecnológico bajo hacia productos medianamente intensivos en tecnología ha tenido importantes consecuencias para el crecimiento económico de los PBO. Nuestro análisis también confirma que existe un fuerte efecto de convergencia hacia los países más desarrollados. Por último, en consonancia con los resultados en el Capítulo 2, corroboramos el efecto positivo y significativo que las inversiones y la acumulación de capital tienen sobre el crecimiento en estas economías.

Otra cuestión que se analiza en este Capítulo hace referencia a los principales determinantes subyacentes a la variación de la sofisticación de las exportaciones. Es decir, ¿qué es lo que permite a un país mejorar la sofisticación de sus exportaciones? La evidencia obtenida a este respecto sostiene que tanto el desarrollo económico como financiero son factores cruciales en la estimulación de la sofisticación de la cesta de exportaciones en los PBO. Además, también observamos que una menor concentración de las exportaciones contribuye a un aumento de su complejidad y por lo tanto a un mayor crecimiento económico.

En general, nuestros resultados apoyan la idea de que las reformas estructurales destinadas a mejorar la estructura de la producción en los PBO aumentan la sofisticación de las exportaciones en la región, pudiendo ser por tanto consideradas un importante estímulo para el crecimiento de los ingresos. La promoción de las políticas dirigidas específicamente a la creciente sofisticación de la producción, y en particular de aquella 
con un nivel medio de conocimientos y tecnología, tiene un potencial significativo para mejorar el futuro desarrollo económico de estos países.

\section{Futuras líneas de investigación}

Por último, hay algunas líneas futuras de investigación prometedoras que pueden ayudar a profundizar aún más en este estudio.

En primer lugar, sería beneficioso extender el análisis de los determinantes que influyen en la participación de los PBO en las redes internacionales de producción. En ese sentido, si bien los resultados de este estudio están en línea con la literatura de la fragmentación internacional de la producción, somos conscientes de que estos determinantes pueden diferir de una industria a otra dependiendo de los patrones de especialización de los países. Por lo tanto, una futura vía de investigación que dirija de forma más detallada las actuaciones políticas podría ser realizar un análisis en profundidad industria por industria.

En segundo lugar, el estudio de los efectos que sobre el crecimiento tiene una la mayor participación de los PBO en el comercio de procesamiento, confirmó que cada país de los Balcanes occidentales parece haberse especializado en diferentes industrias cambiando gradualmente hacia industrias con valor añadido más alto. En ese sentido, una mayor extensión de este análisis debe centrarse en un enfoque sectorial de este fenómeno, especialmente teniendo en cuenta que la especialización productiva implica lógicamente diferentes patrones de comercio de procesamiento para diferentes industrias.

Por último, en cuanto a la transformación observada de la estructura productiva en los PBO sería interesante conocer más profundamente si la relación entre la sofisticación de las exportaciones y el crecimiento de la renta per cápita depende del régimen de comercio (procesamiento $\mathrm{u}$ ordinario) y el tipo de propiedad (nacional o extranjera) de las empresas exportadoras. Además, el avance en el diseño y construcción de un índice de sofisticación de importación (similar al que se ha usado para los bienes exportados) podría ser útil para comprobar si el crecimiento se ve también afectado por las importaciones de bienes más sofisticados (o bienes de capital). 


\title{
Chapter I
}

\section{Fragmentation and parts and components trade in the Western Balkan countries}

\begin{abstract}
As a consequence of the increasing globalization and integration of the world's markets, there has been an intensive process of international fragmentation of the production over the last few decades. This phenomenon whereby previously integrated productive activities are segmented and internationally spread is reflected in the rapid increase in parts and components trade, growing at higher rates than final goods trade. In this process, the Western Balkan countries have not been an exception. With their recent integration into the global markets, the WBC have witnessed growth in parts and components trade that has even exceeded the world average. This chapter examines the determinants of the trade that stems from the international fragmentation of production in the WBC. Using a panel data set of disaggregated bilateral trade flows, we estimate gravity equations for the period 2000-2009. Our findings support the hypothesis drawn from the theory of fragmentation that trade in parts and components is motivated by labor cost differences and by geographical and proximity reasons. The relevance of additional service link costs, as well as the influence of institutional similarity and infrastructure quality or political-economic agreements is also confirmed by our empirical research.

Key words: fragmentation, trade in parts and components, Western Balkan countries, gravity model
\end{abstract}

JEL Classification: F10, F14, F15 


\subsection{Introduction}

Is the label "Made in ..." on your computer telling the whole truth? The majority of manufactured products that we use on a daily basis are not made entirely in the country where they are finally assembled or sold. Most probably, some of the parts and components are provided by foreign firms. This process may go even deeper. A part or component from a particular country, used to assemble the final product, might already be composed of inputs from other countries that are used indirectly in the production of the final product. Ultimately this is how international fragmentation of the production process emerges resulting in the creation of international production networks.

As shown by Jones et al. (2005), the rapid growth of parts and components trade is a natural consequence of this phenomenon, where a final good is the result of a production process that takes place in different locations. International fragmentation of production is mainly associated with the activities of multi-national companies (MNC). This occurs when different stages of production take place in subsidiaries located in different countries, thus leading to the creation of intra-firm trade. However, this process is not confined to the activities of a MNC, but may also occur through arm's-length transactions (Venables, 1999).

The pattern of trade that emerges from international fragmentation differs depending on the reasons that drive the delocalization of the production process. As Deardorff (1998) mentioned, fragmentation of production will only occur when the benefits of this process that come from the location advantages of internationalization exceed the coordination and transportation costs of integrated production. As indicated by Jones and Kierzkowski (1990), the fragmentation process involving countries with different levels of development and income will be due to location advantages that stem from different factor endowments, such as lower wages and the availability of raw-materials. Conversely, in the most advanced economies with similar incomes (mostly Western European countries, the US, Canada and Japan), we would expect trade in differentiated products to be driven by imperfect competition and variety preferences. According to Krugman (1980) and Krugman and Helpman (1985), in this case, trade in goods will be 
mainly horizontal and will not be characterized by comparative advantages, but rather by income levels, economies of scale and the number of varieties produced and consumed. Thus, in the former case firms will be mainly efficiency-seeking and oriented towards reducing production costs, while in the latter they will be serving local market demand. Consequently, researching the nature of parts and components trade will allow us to shed some light on the causes and consequences of the international fragmentation of production.

During the last decade, many studies have empirically analyzed the phenomenon of the international fragmentation of production, focusing on East Asia, the EU and the United States (US). It is worth highlighting the work by Athukorola and Yamashita (2006) and Kimura et al. (2007) for East Asia; Baldone et al. (2001), Egger and Egger (2005) and Kaminski and Ng (2005) for EU; and Görg (2000), Swenson (2005) and Clark (2006) for the US. Studies like Yeats (2001) or Jones et al. (2005) analyze the phenomenon on a more global basis, covering countries from all three regions. A common outcome of this literature is that trade in intermediate goods is expanding more rapidly than conventional final-goods trade, as a result of the increasing dis-agglomeration of production. By exploiting the advantages of favorable policy settings for international production and low service link costs, as well as inter-country wage differentials, companies benefit from the international fragmentation of the production process.

The Western Balkan countries, comprising Albania, Bosnia and Herzegovina, Croatia, Macedonia, Montenegro and Serbia, are no exception in this phenomenon ${ }^{4}$. The recent economic modernization and international opening-up of the WBC, as well as the spectacular increase in their trade in parts and components over the last decade makes this region an interesting case to examine.

\footnotetext{
${ }^{4}$ Kosovo was not included in the study because of data limitations.
} 
Figure 1. Annual growth in parts and components trade

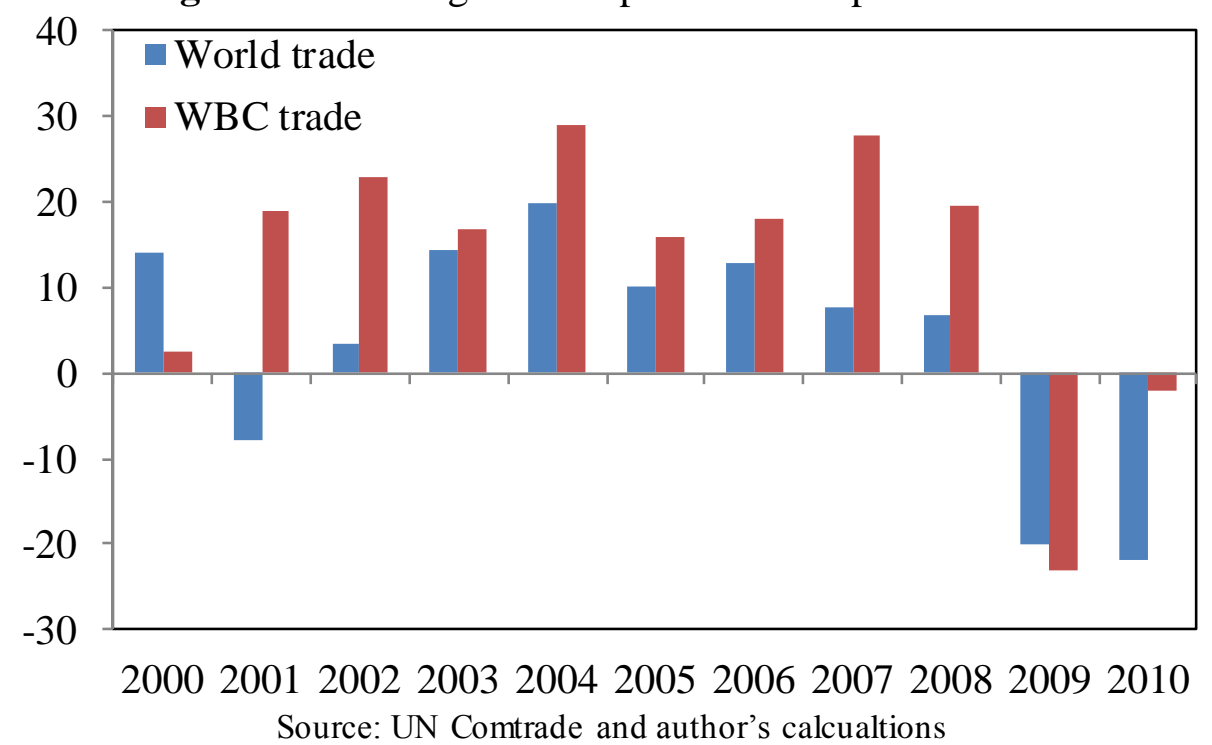

As can be seen in Figure 1, annual growth in parts and components trade in the WBC is well above world growth over the last decade (except for the years 2000 and 2009). Average growth in parts and components imports and exports over the period 2000-2010 in the WBC was more than two and a half times higher than the respective world growthrate. Although there has been a decrease in the last two years of the sample due to the collapse in trade following the financial crisis, the WBC have recovered quite quickly. In 2010, WBC growth is only slightly negative, compared to the significantly negative growth rate at world level.

Using disaggregated trade data ${ }^{5}$, this chapter examines the nature and determinants of bilateral trade in parts and components in the WBC. Following the empirical literature, parts and components trade is employed as an indicator of fragmentation between the WBC and their most important trading partners ${ }^{6}$. The sample period extends from 2000 to 2009 and is determined by the availability of data for the whole country sample. This study considers factors that may stimulate or deter trade in parts and components as well as country-specific effects. In order to do so, a gravity panel data model is estimated. To

\footnotetext{
${ }^{5}$ See Appendix A.1. for a greater detail of the used data in this study.

6 Most empirical research uses bilateral trade in parts and components as an indicator of fragmentation. See, for example, Kimura at al. (2007), Kaminski and Ng (2005) and Athukorola and Yamashita (2006).
} 
the best of our knowledge, there has been no previous attempt to empirically test what determines international fragmentation in the WBC.

The remainder of the chapter is structured as follows. In the next section we present some stylized facts. Next, we analyze the theoretical background referring to the international fragmentation of the production process. Some empirical evidence is presented in the following section. The methodological framework and the different explanatory variables used are then described. The following section presents and explains the empirical results and the final section concludes.

\subsection{Stylized facts}

Until the mid-1990s, owing to political instability and war conflicts, the WBC had been beyond the direct reach of foreign firms. By the end of the decade, they had all opened up to foreign investment with the exception of Serbia and Montenegro, which opened up after the war in Kosovo in 1999 (and once former president Slobodan Miloshevic had been overthrown). One key issue in this external opening was the aspiration to join the EU. Stabilization and Association Agreements (SAA) were subsequently signed with all WBC, which initiated the long accession process that should eventually result in EU membership. ${ }^{7}$ This integration process gives the WBC the opportunity to participate more actively in the IPN.

Following the fall of the former Soviet Union and the events that followed in Eastern European countries, the WBC entered a process of economic transition to replace their former planned economic systems with market economies. Reform programs pursued aims such as liberalization, stabilization and privatization. ${ }^{8}$ In order to converge to the

\footnotetext{
7 Albania submitted its application for EU membership in April 2009 and is currently a potential candidate; Bosnia and Herzegovina is also considered a potential candidate country, but formal application has not yet been submitted; Croatia joined the EU in July 2013, and the formal signing of the acceptance process was carried out at the EU summit in December 2011; Macedonia was granted candidate country status for EU membership in 2005, but negotiations with the EU have not yet begun due to the unresolved "name" issue with Greece; Montenegro started negotiations with the EU in June 2012; finally, Serbia has started the negotiation process in 2014.

8 Barriers to trade including non-tariff barriers were removed and customs systems and legal practices were aligned with those in the EU. The trade and transport facilitation program for South Eastern Europe helped
} 
'acquis communautaire', this harmonization process has expanded to areas such as market liberalization (like telecommunications and financial systems), registering property, starting-up a business, protecting investors or enforcing contracts. All these measures promote a business-friendly environment and minimal disruption in transportation and communication between production segments as a necessary condition to participate in the international division of labor and trade.

Table 1. Foreign direct investment as \% of GDP

\begin{tabular}{lccccccccccc}
\hline & $\mathbf{2 0 0 0}$ & $\mathbf{2 0 0 1}$ & $\mathbf{2 0 0 2}$ & $\mathbf{2 0 0 3}$ & $\mathbf{2 0 0 4}$ & $\mathbf{2 0 0 5}$ & $\mathbf{2 0 0 6}$ & $\mathbf{2 0 0 7}$ & $\mathbf{2 0 0 8}$ & $\mathbf{2 0 0 9}$ & $\mathbf{2 0 1 0}$ \\
\hline \hline Albania & 3.9 & 5.1 & 3.0 & 3.1 & 4.6 & 3.1 & 3.6 & 6.1 & 9.6 & 11.2 & 9.1 \\
Bosnia and & 2.7 & 2.1 & 4.0 & 4.6 & 7.1 & 5.7 & 6.7 & 11.9 & 5.4 & 0.8 & 2.6 \\
Herzegovina & & & & & & & & & & & \\
Croatia & 4.6 & 3.7 & 1.5 & 4.9 & 2.2 & 3.4 & 6.0 & 7.0 & 5.5 & 2.9 & 2.1 \\
Macedonia & 5.7 & 12.1 & 2.6 & 2.4 & 5.7 & 2.3 & 6.2 & 8.8 & 6.2 & 2.8 & 3.2 \\
$\begin{array}{l}\text { Serbia and } \\
\text { Montenegro }\end{array}$ & 0.8 & 1.4 & 3.5 & 6.6 & 4.1 & 7.8 & 16.2 & 7.8 & 5.6 & 4.1 & 3.1 \\
\hline
\end{tabular}

Source: World Development Indicators

These institutional preconditions, combined with the availability of competitive overall cost structure (labor, land and utilities cheaper than new EU member countries) and geographical proximity to the EU, make the WBC attractive for both efficiency-seeking and market-seeking MNC. As a result of this process, foreign investment in these countries began to increase considerably. As can be seen in Table 1, foreign direct investment (FDI) in each WBC displays a significant increase over the last decade, until 2008. A decline is witnessed in 2009 and 2010 due to the financial crisis.

customs reforms and improved coordination between border control agencies, as well as eliminating bottlenecks at border crossings in the region. 
Table 2. Trade in machinery and transport equipment: total and parts and components of the same groups, 2000-2009 (mil. US\$)

\begin{tabular}{|c|c|c|c|c|c|c|}
\hline & \multicolumn{2}{|c|}{$\begin{array}{l}\text { Machinery final goods } \\
\text { trade }\end{array}$} & \multicolumn{2}{|c|}{$\begin{array}{l}\text { Parts\& Components } \\
\text { trade }\end{array}$} & \multicolumn{2}{|c|}{$\begin{array}{l}\text { P\&C/Machinery final } \\
\text { goods }\end{array}$} \\
\hline & Imports & Exports & Imports & Exports & Imports & Exports \\
\hline \multicolumn{7}{|l|}{ "World } \\
\hline 2000 & 2203795 & 2162897 & 1117222 & 1117097 & 0.51 & 0.52 \\
\hline 2004 & 3075915 & 3031530 & 1474657 & 1456353 & 0.48 & 0.48 \\
\hline 2009 & 3793472 & 3848402 & 1706771 & 1634764 & 0.45 & 0.42 \\
\hline growth rate & $72 \%$ & $78 \%$ & $53 \%$ & $46 \%$ & & \\
\hline \multicolumn{7}{|c|}{ Western Balkans } \\
\hline 2000 & 4823 & 2291 & 678 & 437 & 0.14 & 0.19 \\
\hline 2004 & 13614 & 5455 & 2171 & 1119 & 0.16 & 0.21 \\
\hline $2009 *$ & 16721 & 7925 & 2847 & 2449 & 0.17 & 0.31 \\
\hline growth rate & $23 \%$ & $46 \%$ & $31 \%$ & $119 \%$ & & \\
\hline $2009 * *$ & 14104 & 6487 & 2425 & 1940 & 0.17 & 0.3 \\
\hline growth rate & $192 \%$ & $183 \%$ & $258 \%$ & $344 \%$ & & \\
\hline \multicolumn{7}{|l|}{$E U-10$} \\
\hline 2000 & 52382 & 52046 & 28451 & 22907 & 0.54 & 0.44 \\
\hline 2004 & 109529 & 115869 & 57974 & 54895 & 0.53 & 0.47 \\
\hline 2009 & 152759 & 211585 & 91989 & 80651 & 0.6 & 0.38 \\
\hline growth rate & $192 \%$ & $307 \%$ & $223 \%$ & $252 \%$ & & \\
\hline \multicolumn{7}{|l|}{$E U-15$} \\
\hline 2000 & 780221 & 835583 & 346150 & 346.907 & 0.44 & 0.42 \\
\hline 2004 & 1140510 & 1220609 & 454234 & 487.889 & 0.4 & 0.4 \\
\hline 2009 & 1289273 & 1335803 & 456219 & 507.219 & 0.35 & 0.38 \\
\hline growth rate & $65 \%$ & $60 \%$ & $32 \%$ & $46 \%$ & & \\
\hline
\end{tabular}

* Data for the WBC with Bosnia and Herzegovina. The comparison is with 2004.

** Data for the WBC without Bosnia and Herzegovina. The comparison is with 2000.

Source: UN Comtrade database and author's calculations.

The implication of this process has been a significant increase in parts and components trade, as can be observed in Figure 1. This increase is even larger than the one experienced in final goods trade. Table 2 compares the imports and exports of machinery and transport equipment and miscellaneous manufactured articles (hereafter machinery goods) along with imports and exports of parts and components of the same groups. ${ }^{9}$ As

\footnotetext{
${ }^{9}$ The coverage of the parts and components included in the analysis is presented in the code list in Appendix Table A.1.
} 
can be seen, world trade in parts and components (imports and exports) increased by 53\% and $46 \%$ for the period 2000-2009, respectively. Western Balkan countries not only achieved faster growth in imports and exports of machinery final goods (growing at $192 \%$ and $183 \%$, respectively), but also recorded even more intense growth in parts and components trade. The latter increased by $258 \%$ and $344 \%$ (in imports and exports, respectively) during the same period, which is more than double the growth rate of this type of trade at world level. Furthermore, the increase in WBC trade in parts and components was far greater than the increase in the other two regions in Europe. Compared to the EU-15, the increase is threefold, while for the EU-10, the difference is more than 30 percentage points in the case of imports and more than 90 in the case of exports.

However, this trade is not evenly distributed across countries. Bilateral trade is mainly concentrated in only a few economic areas. The EU is the main trading partner, accounting for more than $70 \%$ of all imports and exports. Within the EU itself, the EU-15 countries (mainly Germany and Italy) are by far the most important partners. In 2000, they accounted for $67 \%$ of all machinery parts and components imports. However, that figure had dropped to $58 \%$ by 2009 due to the increase in the share of EU-10 and East Asia (mainly China). The situation on the export side has changed significantly in favor of trade with EU countries, from $75 \%$ in 2000 to $83 \%$ in 2009.

These stylized facts reveal not only the increasing relevance of trade in intermediate goods in the $\mathrm{WBC}$, but also the potential change in its geographical pattern. In order to understand the above changes, it is important to ascertain what drives the decision of firms when they choose to locate part of their production in the WBC. Discovering the nature of the IPN in these countries will help us to determine not only the pattern of trade in parts and components, but also the potential impact of this process on economic performance within this region. In order to explore this issue further, some theoretical aspects related to the international fragmentation of the production process are presented in next section. 


\subsection{Theoretical background of fragmentation theory}

It is a well-known fact that international trade does not only occur when each partner country is specialized in products from different industries, as explained by traditional comparative advantage theories (Ricardian and Heckscher-Ohlin models). Countries may produce different types of products from the same industry, which gives rise to intraindustry trade (IIT).

The concept of intra-industry trade was first introduced by Grubel and Lloyd (1971, 1975). The understanding of this type of trade was further formalized in theoretical terms by Krugman (1980) and Krugman and Helpman (1985), who provide seminal contributions along the lines of Dixit and Stiglitz (1977). According to these models, trade flows between industrialized countries should not be characterized by comparative advantages. On the contrary, the exchange of homogeneous goods (horizontal IIT) is driven by imperfect competition and variety preferences.

However, intra-industry trade in intermediate goods is not fully explained by these initial models of horizontal IIT. The specialization pattern of trade in intermediate goods seems to be more appropriately explained by the literature on vertical IIT and the international fragmentation of the production process. ${ }^{10}$ According to Jones et al. (2002), international fragmentation or the splitting-up of an initially integrated production process into two or more production segments that are located in different countries, will result in vertical IIT. In this sense, while the traditional theory of trade does not fully explain why horizontal IIT takes place, it does explain vertical specialization and hence the international fragmentation of production.

The first general framework to analyze fragmentation was introduced by Jones and Kierzkowski (1990). For these authors, the fragmentation of the production process into several stages located in different countries allows firms to select locations that are better suited in terms of factor endowments or productivities. This would imply, on the one hand, that the most labor-intensive stages of the production process are located in the

\footnotetext{
${ }^{10}$ Vertical IIT is defined as the simultaneous exporting and importing of products in the same industry, but at different stages of production.
} 
most labor-abundant (lower wage) countries. On the other hand, as the different stages of the production process might require different labor skills, some countries' labor skills might be more appropriate to one stage than others (Ricardian productivity differences). ${ }^{11}$

However, the delocalization of the production process needs to be coordinated and linked, which will entail service link costs such as transportation, communication and other coordination activities. Owing to the fact that the increasing output of the different production stages would only slightly increase total service link costs, the larger the size of the firm and the market, the more cost-efficient the fragmentation would be. Therefore, with service-link costs, the scale matters. In this sense, the ideas of the new trade theory and new economic geography, concerning increasing returns to scale are also implied by the fragmentation literature. Indeed, fragmentation will only occur if each production stage is more closely matched to its factor intensities and factor productivities in order to offset the increase in service link costs. As Jones and Kierzkowski (1990) conclude, fragmentation can lower total production costs only at the expense of higher service link requirements. $^{12}$

The international fragmentation of production therefore allows a more in-depth specialization to take place within a single industry. On the one hand, a country that does not have a comparative advantage in each stage of the production process will be able to specialize in the assembly of a final good. On the other hand, a country that does not have a comparative advantage in the production of a final good will be able to produce at least some parts of that good. Both processes will eventually increase trade in intermediate goods (Deardorff 1998, 2001).

\subsection{Related research}

Many empirical works have analyzed the determinants of the international fragmentation of production. These studies differ in terms of the countries analyzed, the methodologies and data employed and/or the results. Different authors even employ different terms and

\footnotetext{
${ }_{11}^{11}$ See, for example, Arndt (1997), Deardorff (2001a), or Arndt and Kierzkowski (2001).

12 Other important contributions to the theory of fragmentation can be found in Arndt (1997), Arndt and Kierzkowski (2001), Jones and Kierzkowski (2001) and Deardorff (2001).
} 
measures to basically describe the same phenomenon. ${ }^{13}$ The strictest definition of this process entails the well-known inward-outward processing trade. That is, in this case the home-country firm exports intermediate goods for further processing in a foreign country, after which the goods are re-imported by the home-country firm. A broader definition of fragmentation measures this process through volumes of trade flows in intermediate goods or parts and components (Baldone et al. 2001, Yeats, 2001, Athukorola and Yamashita ,2006 and Kimura et al., 2007). More recently, a relatively new line of research involving global input-output matrices and trade in value added has emerged. General findings from these works are that inter-mediate goods trade has been expanding faster than trade in finished goods, and that fragmentation trade and participation in GVCs is a powerful driver of growth ${ }^{14}$.

The focus of most of these studies has been on the three main economic regions in the world: the US, the EU and East Asia. International fragmentation of the production process by US firms is, for instance, studied by Swenson (2005) and Clark (2006). The first study analyzes the cross-country pattern of US outsourcing activities between 1980 and 2000. It explains how outsourcing is affected by cost changes in different host countries. The study finds that US outsourcing activities will increase as these costs fall or when a competitor country's costs rise. Clark (2006) investigates the determinants that influence US firms to engage in vertical specialization. This research shows that the main reason for US firms to engage in fragmentation is to counter a comparative disadvantage in home production. For Clark (2006), the factors that influence the selection of new locations include market size, proximity to foreign countries, political freedom, degree of exchange rate distortion and labor force availability and quality.

Studies that analyze the fragmentation process in Europe include the papers by Egger and Egger (2005) and Kaminski and Ng (2005). Egger and Egger (2005) use data on the bilateral outward and inward processing exports and imports of $12 \mathrm{EU}$ economies. The

\footnotetext{
13 Such as slicing up the value chain (Krugman 1995), outsourcing (Feenstra and Hanson 1997), disintegration of production (Feenstra 1998), intra-product specialization (Arndt 1997), vertical specialization (Hummels et al. 2001), or fragmentation (Jones and Kierzkowski 1990; Deardorff 2001).

14 See for example: Johnson and Noguera (2012), Koopman et al. (2014) or Baldwin, R. and LopezGonzalez, J. (2014).
} 
authors find that the EU's outward processing trade is to a relatively large extent determined in line with standard Heckscher-Ohlin arguments. Furthermore, they argue that for outward processing trade, infrastructure variables (such as the telephone and road networks or the electricity supply in the partner country) are also relevant. Kaminski and $\mathrm{Ng}$ (2005) analyze the case of the new EU member countries (EU-10) by investigating whether these countries have become part of the production and distribution networks, concluding that they had been integrated into the global networks.

Athukorala and Yamashita (2006) and Kimura et al. (2007) study the international fragmentation of production in East Asia through the estimation of gravity equations. They find not only that parts and components trade is expanding more rapidly than final goods trade in East Asia, but also that the degree of dependence on this form of international specialization is proportionately larger in East Asia than in North America or Western Europe. This seems to be the result of the relatively more favorable policy setting for international production in the region (agglomeration benefits and wage differentials), which is in line with the basic fragmentation literature. Comparing East Asia to Western Europe, Kimura et al. (2007) conclude that the fragmentation theory is well suited to explaining the mechanics of international production and distribution networks in East Asia, while the traditional horizontal product differentiation model better explains intra-industry trade between Western European countries. They also show that the difference in service-link costs and location advantages are empirically relevant and play a significant role in determining the magnitude of trade in machinery parts and components, as stated by the fragmentation literature. ${ }^{15}$

Jones et al. (2005), who analyze the areas of North America Free Trade Agreement (NAFTA), EU-15 and East Asia, conclude that the optimal degree of fragmentation depends on the size of the market, as the scale of production would determine the length to which such a division of labor can proceed. The importance of the size of the market on trade and fragmentation can be also found in the research by Egger and Falkinger (2002 and 2003) and Burda and Dluhosch (2002).

\footnotetext{
${ }^{15}$ Other studies that highlight the importance of service-link and location advantages include Bergstrand and Egger (2006) and Golub et al. (2007).
} 
The conclusion drawn from the brief review of the literature on fragmentation is that not only factor endowment differences, but also service-link costs are the main driving forces behind the fragmentation of the production process and consequently of trade in parts and components. These service-link costs include aspects such as political settings, institutional and infrastructure quality. Hence, here we consider these factors as the key determinants of parts and components trade.

\subsection{Empirical analysis}

\subsubsection{Model specification and estimation methodology}

Following previous empirical research' we analyze the nature of trade in parts and components in the Western Balkans by estimating a gravity model ${ }^{16}$. This model, initially developed by Tinbergen (1962) and later expanded by Anderson (1979), explains the volume of bilateral trade flows according to the size of the trading economies and bilateral trade costs (variables such as physical distance, common border or language are considered).

Despite lacking strong theoretical foundation, gravity models have shown significant empirical robustness and explanatory power for describing trade flows. Recently, Bergstrand and Egger (2010) developed a theoretical model that encompasses bilateral final goods trade, intermediate goods trade and foreign direct investment flows. This model simultaneously estimates gravity equations for all these flows.

The gravity equation employed in this research augments the standard gravity-type variables i.e. economic size (size), distance (dist), and common border (border), with other factors that have been suggested by the fragmentation literature, such as differences in factor endowments (endow) and market size dissimilarities (ssize). We also include variables that take into account the quality of infrastructure, institutional similarity or political-economic agreements $\left(X_{k}\right)$.

\footnotetext{
${ }^{16}$ Gravity models have been widely used in the empirical literature of trade in parts and components. See, for instance, the papers by Athukorala and Yamashita (2006) and Kimura et al. (2007).
} 
More specifically, the estimating equation takes the following form:

$$
\begin{aligned}
\ln \left({\text { pctrade })_{i j t}}\right. & =\beta_{0}+\beta_{1} \text { size }_{i j t}+\beta_{2} \text { dist }_{i j t}+\beta_{3} \text { border }_{i j}+\beta_{4} \text { endow }_{i j t}+\beta_{5} \text { ssize }_{i t} \\
& +\sum_{k} \gamma_{k} X_{k, i j t}+\lambda_{t}+\mu_{i j}+\varepsilon_{i j t}
\end{aligned}
$$

where $i$ and $j$ are home and host-country indexes, respectively and $t$ denotes time. The error term comprises (fixed or random) unobserved bilateral effects, $\mu_{i j}$, and the remaining error $\varepsilon_{i j t}$, assumed to be independent across countries and over time. The countries included in the data set are presented in Appendix A.2. The years analyzed are 2000, 2003, 2006 and $2009^{17}$. As mentioned, the dependent variable stands for the trade flows in parts and components between the WB country and its trading partner. The definitions and sources of all variables are detailed in Appendix A.3.

The above equation has been estimated using a panel data approach. This methodology allows us to control for country-specific differences in technology, production and socioeconomic factors, thus avoiding the misspecification problems that individual heterogeneity involves ${ }^{18}$. Moreover, it is a well-known fact that panel data provide more degrees of freedom, less collinearity and therefore more efficiency. The decision regarding whether to consider unobserved country-specific effects as fixed or random was made on the basis of the Hausman test. The models have been estimated with both home-country and country-pair effects ${ }^{19}$. For the sake of robustness, we have also estimated the model using Ordinary Least Squares (OLS) and the results do not differ significantly.

\subsubsection{Data and variables}

Data for parts and components trade (pctrade) were drawn from the United Nations Commodity Trade Statistics Database (UN Comtrade database) using the Standard International Trade Classification (SITC) Revision 3. Machinery and transport equipment

\footnotetext{
${ }_{18}^{17}$ Data for 2004 were used for Serbia and Montenegro because data for 2003 were not available.

18 See Hsiao (1986).

19 The Hausman test has been obtained from the models with country-pair effects.
} 
(group 7) and miscellaneous manufactured articles (group 8) provide the basis for the empirical analysis. It contains a total of 145 product categories.

Trade in parts and components includes imports of country $i$ from country $j$, as well as exports from country $i$ to country $j$, for which data on parts and components are available. Hence, not only parts and components imports are considered, but also two-way trade volumes between countries. There are 5 different groups (the WBC) in total out of which each country is analyzed according to its bilateral trade relations with a set of 23 partner countries.

Following previous applications of the gravity model, we use home and foreign country GDP to measure market size, (Egger and Egger, 2005). The importance of this variable for the international fragmentation of production has been emphasized on many occasions. According to Jones et al (2005), the optimal degree of fragmentation depends on the size of the market, as long as the scale of production determines the length to which such a division of labor can proceed. This idea would be in line with the new theory of trade under imperfect competition. For Grossman and Helpman (2005), in a 'thicker market' that includes a greater number of firms, it should be easier to find a partner firm with the appropriate skills and technology to produce the fragmented component. So, the larger the international market, the greater the opportunities to produce differentiated intermediate goods.

The new trade theory and new economic geography models have further pointed out the importance of differences in market size in determining the pattern of trade (Helpman, 1987). According to these models, the more similar countries are in size, the larger the share of IIT. Thus, trade in parts and components should be positively affected by the fact that trading partners are more similar in size. The similarity of market size is captured here by the similarity index proposed by Helpman $(1987)^{20}$.

\footnotetext{
${ }^{20}$ The similarity of country size index à la Helpman (1987) is defined as:

$$
\log \left[1-\left(\frac{G D P i t}{\text { GDPit }+ \text { GDPjt }}\right)^{2}-\left(\frac{G D P j t}{\text { GDPit }+ \text { GDPjt }}\right)^{2}\right]
$$
}

where indices $i$ and $j$ refer to home and foreign countries, respectively, $t$ denotes time and GDP is a country's real GDP. 
As noted previously, the exploitation of comparative advantages that stems from differences in relative factor endowments is viewed by many authors as one of the main reasons for international fragmentation (Arndt 1997; Deardorff 2001; Jones and Kierzkowski 1990 and 2001). According to these authors, international fragmentation is more likely to occur between countries with different factor endowments, based on the standard comparative advantage justification for trade. As in other applications of the gravity model, we proxy the differences in factor endowments by the difference in per capita GDP between the WBC and their trading partners.

Transport costs (measured by geographical distance) between production stages are commonly used as service-link costs (Kimura et al., 2007). Bergstrand and Egger (2006) suggest that the level of trade costs should negatively impact the share of intra-industry trade. According to Athukorala and Yamashita (2006) and Golub et al. (2007), transportation costs might be more relevant for trade in parts and components than for trade in final goods. They argue that transportation costs would rise due to the number of shipments among different production stages before final assembly takes place. We also include a common border dummy and two regional variables (saa and yugo) that take into account whether or not the WB country has signed a Stabilization and Association Agreement with the EU and whether or not the trading partners are republics of the former Yugoslavia, respectively.

More recently, many studies have also insisted on the importance of the quality of infrastructure and institutional differences in the international fragmentation of production $^{21}$. Infrastructure (infra) is viewed as a cost-effective means of lowering trade costs and thereby promoting the internationalization of firms. For Francois and Manchin (2007), propensity to take part in a trading system depends on access to well-developed infrastructure. Given that higher-quality infrastructure reduces communication and coordination costs, a positive impact of this variable on trade in parts and components is expected. As shown by Cheptea (2007), an improvement at the institutional level promotes trade integration. According to this author, homogeneity in the quality of institutions (instit) may also enhance trade in parts and components. Similar norms of

${ }^{21}$ See, for instance, the work by Egger and Egger (2005) and Jones et al. (2005). 
behavior and levels of trust in doing business may make trading between countries easier (Beugelsdijk and van Schaik, 2001). Institutional similarity means that firms will be more familiar with the formal procedures and informal practices in the other country.

In our model, we have also included the relative exchange rate of the country (exch). Previous empirical work (Swenson, 2000) shows a significant and negative impact of dollar depreciation on outward processing in the case of US firms in terms of foreign inputs becoming more expensive. In line with this, currency depreciation in the WBC might have a positive impact on parts and components exports to their trading partners. Finally, we have added foreign direct investment in the home country $(f d i)$ as an explanatory variable. As the affiliates of the MNC are a direct result of capital flows in the form of FDI in the host country, we would expect this variable to have a positive impact on trade in parts and components. Affiliates usually perform final assembly or processing stages using imported intermediate goods from the parent firm. According to Feenstra and Hanson (1997), the growth of capital stock in the host country encourages the flow of intermediate goods for further processing between the two countries.

\subsection{Estimation results}

Table 3 presents the estimate coefficients for parts and components trade with homecountry specific effects. For comparative purposes, we also present these estimations for final goods trade in Table $4^{22}$. These models have also been estimated with country-pair effects and results are shown in Appendix A.4 and A.5, respectively.

In these tables, two different models are estimated for each trade flow: a baseline model that includes the standard gravity variables together with the factor endowment variable and similarity in size (Model 1) and an extended model, which adds other countryspecific variables (Model 2). Both imports and exports, as well as total trade (imports plus exports), have been calculated.

\footnotetext{
${ }^{22}$ The outcomes of estimating total trade in SITC Rev. 3 groups 7 and 8 are available upon request.
} 
Table 3. Estimation results for parts and components trade (with home-country fixed effects)

\begin{tabular}{|c|c|c|c|c|c|c|}
\hline \multirow[b]{4}{*}{$\begin{array}{l}\text { Dependent } \\
\text { variable }\end{array}$} & \multicolumn{6}{|c|}{ Parts and components } \\
\hline & \multicolumn{2}{|c|}{ Imports } & \multicolumn{2}{|c|}{ Exports } & \multicolumn{2}{|c|}{ Imports + Exports } \\
\hline & Model 1 & Model 2 & Model 1 & Model 2 & Model 1 & Model 2 \\
\hline & $\begin{array}{c}\text { Random } \\
\text { effects }\end{array}$ & $\begin{array}{l}\text { Fixed } \\
\text { effects }\end{array}$ & $\begin{array}{l}\text { Fixed } \\
\text { effects }\end{array}$ & $\begin{array}{c}\text { Random } \\
\text { effects }\end{array}$ & $\begin{array}{l}\text { Fixed } \\
\text { effects }\end{array}$ & $\begin{array}{c}\text { Random } \\
\text { effects }\end{array}$ \\
\hline size & $\begin{array}{c}0.743 * * * \\
(0.102)\end{array}$ & $\begin{array}{c}1.158 * * * \\
(0.051)\end{array}$ & $\begin{array}{c}0.872 * * * \\
(0.115)\end{array}$ & $\begin{array}{c}0.868 * * * \\
(0.090)\end{array}$ & $\begin{array}{c}0.881 * * * \\
(0.106)\end{array}$ & $\begin{array}{c}0.855 * * * \\
(0.064)\end{array}$ \\
\hline dist & $\begin{array}{c}-0.488 * * \\
(0.181)\end{array}$ & $\begin{array}{c}-0.689 * * \\
(0.231)\end{array}$ & $\begin{array}{c}-2.921 * * * \\
(0.481)\end{array}$ & $\begin{array}{c}-3.067 * * * \\
(0.383)\end{array}$ & $\begin{array}{c}-0.914 * * * \\
(0.228)\end{array}$ & $\begin{array}{c}-0.916 * * * \\
(0.178)\end{array}$ \\
\hline border & $\begin{array}{c}1.148 * * * \\
(0.267)\end{array}$ & $\begin{array}{c}0.950 \\
(0.522)\end{array}$ & $\begin{array}{c}0.182 \\
(0.794)\end{array}$ & $\begin{array}{c}0.008 \\
(0.983)\end{array}$ & $\begin{array}{c}1.024 * * * \\
(0.220)\end{array}$ & $\begin{array}{l}0.872 * \\
(0.481)\end{array}$ \\
\hline endow & $\begin{array}{c}-0.225 * \\
(0.100)\end{array}$ & $\begin{array}{c}0.176 \\
(0.110)\end{array}$ & $\begin{array}{c}0.349 * * \\
(0.091)\end{array}$ & $\begin{array}{c}0.681 * * * \\
(0.070)\end{array}$ & $\begin{array}{c}0.131 \\
(0.089)\end{array}$ & $\begin{array}{c}0.077 * \\
(0.043)\end{array}$ \\
\hline ssize & $\begin{array}{c}0.051 \\
(0.152)\end{array}$ & $\begin{array}{c}0.382 * * \\
(0.116)\end{array}$ & $\begin{array}{c}-0.313 * * \\
(0.126)\end{array}$ & $\begin{array}{c}-0.354 * * * \\
(0.102)\end{array}$ & $\begin{array}{c}0.152 \\
(0.111)\end{array}$ & $\begin{array}{c}0.043 \\
(0.057)\end{array}$ \\
\hline infra & & $\begin{array}{c}1.674 * * \\
(0.611)\end{array}$ & & $\begin{array}{c}1.938 * * * \\
(0.308)\end{array}$ & & $\begin{array}{c}0.664 * * * \\
(0.141)\end{array}$ \\
\hline instit & & $\begin{array}{c}0.430 * * * \\
(0.069)\end{array}$ & & $\begin{array}{c}0.450 * * * \\
(0.155)\end{array}$ & & $\begin{array}{c}0.386 * * * \\
(0.083)\end{array}$ \\
\hline yugo & & $\begin{array}{c}2.073 * * * \\
(0.259)\end{array}$ & & $\begin{array}{c}1.452 * * * \\
(0.275)\end{array}$ & & $\begin{array}{c}1.851 * * * \\
(0.199)\end{array}$ \\
\hline saa & & $\begin{array}{c}0.132 \\
(0.067)\end{array}$ & & $\begin{array}{l}-0.134 \\
(0.175)\end{array}$ & & $\begin{array}{l}-0.010 \\
(0.075)\end{array}$ \\
\hline$f d i$ & & $\begin{array}{c}-0.706 * * * \\
(0.169)\end{array}$ & & $\begin{array}{c}0.224 * * * \\
(0.081)\end{array}$ & & $\begin{array}{l}-0.106 \\
(0.092)\end{array}$ \\
\hline exch & & $\begin{array}{c}0.003 \\
(0.080)\end{array}$ & & $\begin{array}{c}0.082 * \\
(0.046)\end{array}$ & & $\begin{array}{c}0.013 \\
(0.029)\end{array}$ \\
\hline const & $\begin{array}{c}-18.17 * * \\
(4.577)\end{array}$ & $\begin{array}{c}-40.60 * * * \\
(3.118)\end{array}$ & $\begin{array}{c}-10.62 * * \\
(3.954)\end{array}$ & $\begin{array}{c}-17.58 * * * \\
(1.451)\end{array}$ & $\begin{array}{c}-21.53 * * * \\
(4.835)\end{array}$ & $\begin{array}{c}-23.10 * * * \\
(2.041)\end{array}$ \\
\hline $\begin{array}{l}\text { Num. of } \\
\text { obser. }\end{array}$ & 374 & 352 & 351 & 329 & 378 & 355 \\
\hline Adj. $R^{2}$ & 0.4308 & 0.6543 & 0.4935 & 0.7230 & 0.5628 & 0.7438 \\
\hline
\end{tabular}

Notes: Figures in parenthesis are the standard errors.**;** and *indicate that the results are statis tically significant at the $1 \%, 5 \%$ and $10 \%$ levels.

Source: Authors' calculation based on UN Comtrade database. 
Table 4. Estimation results for final goods trade (with home-country fixed effects)

\begin{tabular}{|c|c|c|c|c|c|c|}
\hline \multirow[b]{4}{*}{$\begin{array}{l}\text { Dependent } \\
\text { variable }\end{array}$} & \multicolumn{6}{|c|}{ Final goods } \\
\hline & \multicolumn{2}{|c|}{ Imports } & \multicolumn{2}{|c|}{ Exports } & \multicolumn{2}{|c|}{ Imports + Exports } \\
\hline & Model 1 & Model 2 & Model 1 & Model 2 & Model 1 & Model 2 \\
\hline & $\begin{array}{l}\text { Random } \\
\text { effects }\end{array}$ & $\begin{array}{l}\text { Fixed } \\
\text { effects }\end{array}$ & $\begin{array}{l}\text { Fixed } \\
\text { effects }\end{array}$ & $\begin{array}{l}\text { Fixed } \\
\text { effects }\end{array}$ & $\begin{array}{l}\text { Random } \\
\text { effects }\end{array}$ & $\begin{array}{l}\text { Fixed } \\
\text { effects }\end{array}$ \\
\hline size & $\begin{array}{c}0.879 * * * \\
(0.085)\end{array}$ & $\begin{array}{c}1.200 * * * \\
(0.125)\end{array}$ & $\begin{array}{c}0.880 * * * \\
(0.136)\end{array}$ & $\begin{array}{c}0.777 * * \\
(0.202)\end{array}$ & $\begin{array}{c}0.794 * * * \\
(0.057)\end{array}$ & $\begin{array}{c}0.744 * * * \\
(0.069)\end{array}$ \\
\hline dist & $\begin{array}{c}-0.596 * * * \\
(0.136)\end{array}$ & $\begin{array}{c}-0.731 * * * \\
(0.134)\end{array}$ & $\begin{array}{c}-3.063 * * * \\
(0.201)\end{array}$ & $\begin{array}{c}-2.643 * * * \\
(0.307)\end{array}$ & $\begin{array}{c}-0.845 * * * \\
(0.080)\end{array}$ & $\begin{array}{c}-0.751 * * * \\
(0.057)\end{array}$ \\
\hline border & $\begin{array}{c}0.890 * * * \\
(0.352)\end{array}$ & $\begin{array}{l}0.784 * \\
(0.339)\end{array}$ & $\begin{array}{c}0.454 \\
(0.581)\end{array}$ & $\begin{array}{c}0.700 \\
(0.625)\end{array}$ & $\begin{array}{c}0.982 * * \\
(0.304)\end{array}$ & $\begin{array}{c}0.978 * * * \\
(0.294)\end{array}$ \\
\hline endow & $\begin{array}{c}0.020 \\
(0.082)\end{array}$ & $\begin{array}{c}0.332 * * \\
(0.106)\end{array}$ & $\begin{array}{c}0.204 * * \\
(0.058)\end{array}$ & $\begin{array}{c}0.203 \\
(0.176)\end{array}$ & $\begin{array}{l}0.154 * \\
(0.060)\end{array}$ & $\begin{array}{c}0.240 * * * \\
(0.059)\end{array}$ \\
\hline ssize & $\begin{array}{c}0.103 * * \\
(0.043)\end{array}$ & $\begin{array}{c}0.376 * * \\
(0.106)\end{array}$ & $\begin{array}{c}0.489 * * * \\
(0.046)\end{array}$ & $\begin{array}{c}-0.483 * * \\
(0.140)\end{array}$ & $\begin{array}{l}-0.061 \\
(0.088)\end{array}$ & $\begin{array}{c}-0.140 * * * \\
(0.042)\end{array}$ \\
\hline infra & & $\begin{array}{c}1.193 * * \\
(0.384)\end{array}$ & & $\begin{array}{c}0.356 \\
(0.631)\end{array}$ & & $\begin{array}{c}0.746 * * * \\
(0.115)\end{array}$ \\
\hline instit & & $\begin{array}{c}0.281 * * * \\
(0.061)\end{array}$ & & $\begin{array}{c}0.182 \\
(0.115)\end{array}$ & & $\begin{array}{c}0.205 * * * \\
(0.048)\end{array}$ \\
\hline yugo & & $\begin{array}{c}1.714 * * * \\
(0.299)\end{array}$ & & $\begin{array}{l}1.558 * \\
(0.644)\end{array}$ & & $\begin{array}{c}1.449 * * * \\
(0.301)\end{array}$ \\
\hline saa & & $\begin{array}{c}0.080 \\
(0.148)\end{array}$ & & $\begin{array}{c}0.291 * * * \\
(0.036)\end{array}$ & & $\begin{array}{c}0.187 * * * \\
(0.060)\end{array}$ \\
\hline$f d i$ & & $\begin{array}{c}-0.710 * * * \\
(0.116)\end{array}$ & & $\begin{array}{l}0.179 * \\
(0.071)\end{array}$ & & $\begin{array}{c}-0.143 * * \\
(0.073)\end{array}$ \\
\hline exch & & $\begin{array}{l}-0.021 \\
(0.062)\end{array}$ & & $\begin{array}{l}0.206 * \\
(0.092)\end{array}$ & & $\begin{array}{l}0.047 * \\
(0.027)\end{array}$ \\
\hline const & $\begin{array}{c}-22.24 * * * \\
(3.545)\end{array}$ & $\begin{array}{c}-38.71 * * * \\
(4.758)\end{array}$ & $\begin{array}{c}-8.86 \\
(5.548)\end{array}$ & $\begin{array}{c}-9.35 \\
(8.379)\end{array}$ & $\begin{array}{c}-16.51 * * * \\
(2.730)\end{array}$ & $\begin{array}{c}-17.45 * * * \\
(2.263)\end{array}$ \\
\hline $\begin{array}{l}\text { Num. of } \\
\text { obser. }\end{array}$ & 379 & 356 & 366 & 343 & 379 & 356 \\
\hline Adj. $\mathrm{R}^{2}$ & 0.6024 & 0.7210 & 0.5979 & 0.6856 & 0.5626 & 0.7777 \\
\hline
\end{tabular}


As can be seen, the outcomes generally support the hypothesis drawn from the fragmentation literature regarding the importance and signs of the explanatory variables. While greater distance discourages bilateral parts and components trade in the WBC, market size significantly promotes it. This last circumstance is in line with the hypothesis that fragmentation of production becomes more cost-efficient the larger the market (Jones and Kierzkowski 1990). Similar findings are presented in Jones et al. (2005) and Kimura et al. (2007). Furthermore, the results are generally the same for all regressions in both models with home-country and country-pair effects, suggesting that the results are robust across specifications.

As expected, the distance variable is negative and strongly significant, verifying the hypothesis that distance-related service-link costs may deter trade in parts and components. According to Jones and Kierzkowski (2001), international fragmentation is more favorable when service-link costs are lowered. Furthermore, if we look at exports and total trade this coefficient is clearly higher for parts and components than for final goods trade, at least for the extended model. This would imply that the influence of distance-related costs on the IPN is greater due to the nature of the production process and multiple border crossings.

The variable that represents similarity in country size also displays the expected positive and significant coefficient in parts and components imports and total trade. However, we find a negative relationship between country-size similarity and exports of parts and components. One possible explanation for this surprising result could be that WBC trade shifted towards the EU countries during the considered period. These countries are quite different from the WBC in relative country size.

In line with the predictions made by models on vertical IIT, significant differences in GDP per capita have a positive influence on both imports and exports. In these models the volume of vertical trade or fragmentation tends to increase the greater the differences in factor endowments and factor prices between two countries. Hence, our estimations would support the hypothesis that efficiency seeking is an important determinant in the parts and components trade of the WBC. This variable is significant for exports in parts and components, explaining the marked increase in exports from the WBC shown above. Similar findings are observed in Egger and Egger (2005). 
Our results also show that the greater the degree of similarity in institutions (economic freedom and legal certainty) in trading partner countries, the more trade flows in parts and components. This is consistent with the idea that institution quality is relevant for both establishing affiliates for processing parts and components in partner countries and for companies becoming trading partners when dealing with arm's-length transactions. Moreover, the coefficients for this variable are more relevant for parts and components than for final goods trade. This reflects that regulatory issues and institutional similarity are more important when firms need to engage in production partnerships, compared to single trade relations in final goods.

As mentioned above, another determinant related to service-link costs is the quality of infrastructure. This variable records a clearly positive and significant influence on bilateral trade in parts and components. This coincides with the results obtained by Jones et al. (2005) and Egger and Egger (2005). Both studies conclude that infrastructure quality as part of service-link costs is extremely relevant in promoting parts and components trade. Furthermore, in view of the fact that there are more shipments between production segments within the IPN, infrastructure quality markedly favors parts and components trade when compared to final goods trade.

Although the shared border dummy has the expected positive sign, it becomes insignificant in the extended model once we control for other variables, such as infrastructure, institutions and regional trade. This is not surprising if we consider that the WBC do not share a border with their most important trading partners (the EU-15). We also find the yugo dummy variable highly significant in all regressions. The coefficient of this variable is considerably higher in trade in parts and components than in the other two types of trade, suggesting the presence of intra-regional ties and the potential of intra-regional production networks, reflected by the trade in parts and components. However, the dummy variable for SAA is not significant in either imports or exports. This could be due to the fact that the only two countries that had signed SAA before 2007/2008 were Croatia and Macedonia, so the overall impact on the region is small.

The coefficient for the bilateral exchange rate, albeit insignificant, appears to have a positive impact on exports of parts and components and total trade, which confirm the idea that a devaluation of the currency will foster exports of parts and components. One 
possible explanation for this variable not being significant would be that most of the sample countries have a de facto peg to the euro.

Interestingly, the results for the FDI variable are rather mixed. We should interpret this outcome with a certain degree of caution since there were no disaggregated data for FDI by country of origin for the WBC to match the FDI flows with the respective bilateral trade in parts and components. Moreover, excluding this variable from the model does not affect the significance of the other variables. ${ }^{23}$

From the above empirical outcomes, we can derive the following conclusions. First, our findings support the idea that the fragmentation process in the $\mathrm{WBC}$ is not only efficiency-seeking but also market-seeking. Firms that seek to lower their production costs through fragmentation should look to larger markets in the region, as market size determines the cost-efficiency of the service-link costs this process entails. But the importance of market size may also indicate that market-seeking decisions for locating some firms are also playing an important role. Second, geographical and institutional distance will discourage trade in parts and components. According to our results, policies designed to implement incentives for foreign investors are not sufficient to participate in the IPN. Improving the institutions to alleviate cost should be considered a priority strategy for policymakers. Third, governments should also recognize that developing quality infrastructure in the region is of vital importance to join the international division of labor and trade, as a higher quality of infrastructures promotes trade integration. Finally, they should be more aware of the high trade potential to be exploited from the intra-regional ties between the republics of the former Yugoslavia, especially in developing regional production networks.

\subsection{Conclusions}

A specific form of international production emerges when some stages of the production process are located in several countries in response to different country characteristics. International fragmentation and international production networks are thus created. The result of this process is increased cross-border trade in parts and components.

\footnotetext{
${ }^{23}$ Results are available upon request.
} 
Throughout the last decade, the WBC have witnessed a substantial increase in trade in parts and components. This suggests that the $\mathrm{WBC}$, as part of their economic modernization process, have played an active role in production-sharing networks, especially within Europe. Thus, identifying the nature and determinants of this type of trade is of particular interest.

According to the fragmentation literature, factor endowment differences and servicelink costs are the driving forces behind the fragmentation of the production process. This theory is confirmed by our estimates, which show how factor endowment differences and market size significantly increase the fragmentation of production in this region, while distance deters it. As expected, these variables have a greater impact on trade in parts and components than on final goods trade.

Infrastructure quality also seems to be of great importance when establishing international production networks. Significant payoffs could be obtained from improving the infrastructure in the $\mathrm{WBC}$, as reliable and inexpensive infrastructure facilitates the fragmentation process.

The degree of similarity in economic freedom and legal certainty in trading partner countries represents another key factor for parts and components trade in the region. Once again, the influence is much greater on parts and components trade than on final goods trade. This result supports the fact that the institutional framework is more relevant when locating part of the production process abroad or performing arm'slength transactions than in single trade relations with final goods.

Finally, our estimates confirm that, as predicted by the theory on international fragmentation, a reduction in the cost of trade associated with regional integration processes has favoured the international division of production processes. We find that the regional ties between the republics of the former Yugoslavia are still very active, even after a decade of wars and conflicts. The importance of these effects is seemingly higher for parts and components trade than for final goods trade.

The results of this study are in line with the established fragmentation literature and provide support for the main arguments therein. We are aware that the determinants of the international fragmentation of production might differ from industry to industry depending on countries' patterns of specialization. Thus, a future avenue of research to 
draw more detailed policy implications could be to perform an in-depth industry-byindustry analysis. 


\section{References}

Anderson, J. E. (1979). 'A Theoretical Foundation for the Gravity Equation', American Economic Review, 69(1), pp.106-116.

Arndt, S. W. (1997). 'Globalization and the Open Economy', North American Journal of Economics and Finance, 8(1), pp. 71-79.

Arndt, S. W. and Kierzkowski, H. (2001). 'Fragmentation: New production and trade patterns the world economy', Oxford University Press, Oxford.

Athukorola, P. and N. Yamashita (2006). 'Product Fragmentation and Trade Integration: East Asia in Global Context', North American Journal of Economics and Finance, 17, pp. 233-56.

Baldone S., Sdogati F., Tavoli L. (2001). 'Patterns and determinants of international fragmentation of production: evidence from outward processing trade between the $\mathrm{EU}$ and the countries of Central- Eastern Europe', Review of World Economics (Weltwirtschaftliches Archiv) 137(1), pp. 80-104

Baldwin, R. and Lopez-Gonzalez, J. (2014). "Supply-chain trade: a portrait of global patterns and several testable hypotheses”. The World Economy 38 (11), pp. 16821721

Bergstrand, J. H. and P. Egger (2006). 'Trade Costs and Intra-Industry Trade', Review of World Economics (Weltwirtschaftliches Archiv), 142(3), pp. 433-458.

Bergstrans, J. H. and P. Egger (2010), 'A General Equilibrium Theory for Estimating Gravity Equations of Bilateral FDI, Final Goods Trade, and Intermediate Goods Trade' in Steven Brakman and Peter van Bergeijk (eds.), The Gravity Model in International Trade: Advances and Applications, Cambridge, UK: Cambridge University Press

Beugelsdijk, S. and A.B.T.M. van Schaik (2001). 'Cultuur en economie', Tijdschrift voor Politieke Ekonomie, 23, pp. 69-84.

Burda, M. C. and B. Dluhosch (2002). 'Cost Competition, Fragmentation and Globalization', Review of International Economics, 10(3), pp. 424-441. 
Cheptea A. (2007). Trade liberalization and institutional reforms, Economics of Transition, 15(2), pp. 211-255.

Clark, D. P. (2006). 'Country and Industry-level Determinants of Vertical Specialization-based Trade', International Economic Journal, 20, pp. 211-15.

Deardorff, A.V. (1998). 'Fragmentation Across Cones', Working Papers 427, Research Seminar in International Economics, University of Michigan, Ann Abor.

Deardorff, A. V. (2001). 'Fragmentation in Simple Trade Models', North American Journal of Economics and Finance, 12,(2), pp. 121-37.

Dixit, A. K and Stiglitz, J. E. (1977). 'Monopolistic Competition and Optimum Product Diversity', American Economic Review, 67 (3), pp. 297-308.

Egger, H. and J. Falkinger (2002). 'Industry Concentration, International Outsourcing and Economic Fundamentals', mimeo, presented at the 4th Annual Conference of the European Trade Study Group, September.

Egger, H. and J.Falkinger (2003). 'The Role of Public Infrastructure for Firm Location and International Outsourcing', mimeo, presented at the 8th Annual Conference on Dynamics, Economic Growth and International Trade, May.

Egger, H. and P. Egger (2005). 'The Determinants of EU Processing Trade',The World Economy, 28, pp. 147-68.

Feenstra, R. C. (1998). 'Integration of trade and disintegration of production in the global economy', Journal of Economic Perspectives, 12, pp. 31-50

Feenstra, R. C. and G.H. Hanson (1997). 'Foreign direct investment and relative wages: evidence from Mexico's Maquiladoras', Journal of International Economics, 42, pp. 371-393.

Francois, J and M. Manchin (2007). "Institutions, Infrastructure, and Trade," CEPR Discussion Paper No. 4152.

Golub, S. S., Jones, R. W., Kierzkowski, H. (2007). 'Globalization and country-specific service links', RCER working paper No. 532 
Görg, H. (2000). 'Fragmentation and Trade: US Inward Processing Trade in the EU', Review of the World Economics (Weltwirtschaftliches Archiv), 136, pp. 403-22.

Grossman, G. M., E. Helpman (2005). 'Outsourcing in a global economy', Review of Economic Studies, 72, pp. 135-159

Grubel, H. and P. J. Lloyd (1971). 'The Empirical Measurement of Intra-industry Trade', Economic Record, 470, pp, 494-517.

Grubel, H. and P. J. Lloyd (1975). 'Intra-Industry Trade: Theory and Measurement of International Trade in Differentiated Products', John Wiley, New York.

Helpman, E., (1987). "Imperfect competition and international trade: Opening remarks," European Economic Review, 31 (1-2), pp. 77-81.

Helpman, E. and P. Krugman (1985), 'Market Structure and Foreign Trade: Increasing Returns, Imperfect Competition, and the International Economy', MIT Press, Cambridge, MA.

Hummels, D., Ishii, J., Yi K-M. (2001). 'The nature and growth of vertical specialization in world trade', Journal of International Economics, 54(1), pp. 75-96

Hsiao C. (1986). Analysis of Panel Data, Cambridge University Press, Cambridge,

Johnson, R.C. and Noguera, G. (2012). “Accounting for intermediates: production sharing and trade in value added”. Journal of International Economics 86: 224-236.

Jones, R. W. and H. Kierzkowski (1990). 'The Role of Services and Production in International Trade: A Theoretical Framework', in R. W. Jones and A. O. Krueger (eds.), The Political Economy of International Trade: Essays in Honor of Robert E. Baldwin, Basil Blackwell, Malden, MA, pp. 31-48.

Jones, R. W. and H. Kierzkowski (2001). 'A Framework for Fragmentation', in S. W. Arndt and H. Kierzkowski (eds.), Fragmentation: New Production Patterns in the World Economy, Oxford University Press, Oxford, pp. 17-34. 
Jones, R. W., H. Kierzkowski and G. Leonard (2002). 'Fragmentation and Intraindustry Trade', in P. J. Lloyd and H. H. Lee (eds.), Frontiers of Research in Intraindustry Trade, Palgrave Macmillan, Basingstoke, pp. 67-86.

Jones, R., H. Kierzkowski and C. Lurong (2005). 'What Does the Evidence Tell Us About Fragmentation and Outsourcing', International Review of Economics and Finance, 14, pp. 305-16.

Kaminski, B. and F. Ng (2005). 'Production disintegration and integration of Central Europe into global markets', International Review of Economics \& Finance, 14(3), pp. 377-390.

Kimura, F., Y. Takahashi and K. Hayakawa (2007). 'Fragmentation and Parts and Components Trade: Comparison between East Asia and Europe', North American Journal of Economics and Finance, 18, pp. 23-40.

Koopman, R., Wang, Z. and Wei, S.-J. (2014). "Tracing value-added and double counting in gross exports". American Economic Review 104: 459-494.

Krugman, P. (1980) 'Scale economies, product differentiation, and the pattern of trade', American Economic Review, 70, pp. 950-959.

Krugman P. (1995). 'Growing world trade: causes and consequences'. Brooking Papers on Economic Activity, 1, pp. 327-377.

Swenson, D. L. (2000). 'Firm Outsourcing Decisions: Evidence from U.S. Foreign Trade Zones', Economic Inquiry, 38(2), pp. 175-89.

Swenson, D. L., (2005). "Overseas assembly and country sourcing choices," Journal of International Economics, 66(1), pp. 107-130.

Tinbergen, J. (1962). 'Shaping the World Economy: Suggestions for an International Economic Policy', The Twentieth Century Fund, New York.

Venables, A. (1999). 'Fragmentation and Multinational Production', European Economic Review 43(4-6), pp. 935-945. 
Yeats, A. J. (2001). 'How big is global production sharing?' in Arndt S. W. and H. Kierzkowski (eds). Fragmentation: new production patterns in the world economy, Oxford University Press, Oxford, pp. 108-144 


\section{Appendix A.1.}

We considered the Standard International Trade Classification Revision 3 as the most appropriate in terms of detail, time, length and comprehensiveness. The groups used in our data are machinery and transport equipment (group 7) and miscellaneous manufactured articles (group 8). The goods classified as parts and components are listed below and the rest of the goods in groups 7 and 8 are classified as final goods.

Table A.1. Code list

7119, 7128, 7131, 7132, 7133, 7138, 7139, 71441, 71449, 7149, 7169, 71819, 71878,
$71899,72119,72129,72139,72198,72199,7239,72439,72449,72467,72468,72488$,
$7249,7259,72689,7269,72719,72729,72819,72839,72847,7285,7351,7359$,
$73719,73729,73739,73749,74128,74135,74139,74149,74159,74172,7419,7429$,
$7438,7439,74419,7449,74519,74529,74539,74568,7459,7469,7479,74839,7489$,
$7491,7591,7599,7649,77129,7722,7723,7724,7725,7726,7728,77429,77549$,
$77579,77589,7761,7762,7763,7764,77688,77689,77817,77819,77829,77833$,
$77835,77848,77869,77879,77883,77885,77889,7841,7842,7843,78535,78536$,
$78537,78689,7919,7929,81211,81215,81219,8138,8139,82119,8218,87119$,
$87139,87149,87199,87319,87329,87412,87414,87424,87426,87439,87449$,
$87454,87456,87469,87479,8749,88114,88115,88123,88124,88134,88136,8859$,
$89111,89113,8912,8919,8941,8989,89935,89937,89949$


Appendix A.2.

Table A.2. Regions and countries included in the dataset

Region

Western Balkans

EU-15

EFTA

East Asia

Others

\section{Country}

Albania, Bosnia and Herzegovina, Croatia, Macedonia, Montenegro and Serbia

Austria, Belgium, Bulgaria, Czech Republic, France, Germany,

Greece, Hungary, Italy, Luxemburg, Netherlands, Slovenia,

Sweden, United Kingdom

Switzerland

China, Japan

Turkey 


\section{Appendix A.3.}

Table A.3. Definitions and data and sources

\begin{tabular}{|c|c|c|}
\hline Abbre viation & Definition & Data Source \\
\hline pcimports & Logarithm of P\&C Imports in the WBC & UN Comtrade database \\
\hline pcexports & $\begin{array}{l}\text { Logarithm of } \mathrm{P} \& \mathrm{C} \text { Exports from the } \\
\text { WBC }\end{array}$ & UN Comtrade database \\
\hline pctotal & $\begin{array}{l}\text { Logarithm of } \mathrm{P} \& \mathrm{C} \text { total trade in the } \\
\text { WBC }\end{array}$ & UN Comtrade database \\
\hline size & $\begin{array}{l}\text { Logarithm of the GDP of the home } \\
\text { country multiplied by the GDP of the } \\
\text { foreign country }\end{array}$ & $\begin{array}{l}\text { World Development Indicators } \\
\text { - World Bank }\end{array}$ \\
\hline dist & $\begin{array}{l}\text { Weighted geographical distance } \\
\text { between countries }\end{array}$ & $\begin{array}{l}\text { Institute for Research on the } \\
\text { International Economy- CEPII } \\
\text { distance database }\end{array}$ \\
\hline border & $\begin{array}{l}\text { Dummy variable ( } 1 \text { if the partner } \\
\text { countries shares a border and } 0 \text { if not) }\end{array}$ & \\
\hline endow & $\begin{array}{l}\text { An index of per capita GDP of } i \text { relative } \\
\text { to that of } j \text {, adjusted by the bilateral } \\
\text { exchange rate }\end{array}$ & $\begin{array}{l}\text { World Development Indicators } \\
\text { - World Bank }\end{array}$ \\
\hline ssize & $\begin{array}{l}\text { Logarithm of similarity index by } \\
\text { Helpman } 1987\end{array}$ & $\begin{array}{l}\text { World Development Indicators } \\
\text { - World Bank }\end{array}$ \\
\hline infra & $\begin{array}{l}\text { Logarithm of the minimum value of the } \\
\text { number of telephone lines in both } \\
\text { countries }\end{array}$ & $\begin{array}{l}\text { World Development Indicators } \\
\text { - World Bank }\end{array}$ \\
\hline instit & $\begin{array}{l}\text { Absolute difference in the Freedom } \\
\text { House index between partner countries }\end{array}$ & $\begin{array}{l}\text { Freedom House - Freedom in } \\
\text { the World }\end{array}$ \\
\hline yugo & $\begin{array}{l}\text { Dummy variable ( } 1 \text { if a WB country } \\
\text { was part of the former Yugoslavia and } 0 \\
\text { if not) }\end{array}$ & \\
\hline$s a a$ & $\begin{array}{l}\text { Dummy variable ( } 1 \text { if a WB country has } \\
\text { an SAA with the EU and } 0 \text { if not) }\end{array}$ & \\
\hline$f d i$ & $\begin{array}{l}\text { Logarithm of the stock of foreign direct } \\
\text { investment in the WB country }\end{array}$ & $\begin{array}{l}\text { World Development Indicators } \\
\text { - World Bank }\end{array}$ \\
\hline exch & $\begin{array}{l}\text { Real effective exchange rate between } \\
\text { countries }\end{array}$ & UNCTAD database \\
\hline
\end{tabular}




\section{Appendix A.4.}

Table A.4. Estimation results for parts and components trade with country-pair fixed effects

\begin{tabular}{|c|c|c|c|c|c|c|}
\hline & \multicolumn{6}{|c|}{ Parts and components } \\
\hline & \multicolumn{2}{|c|}{ Imports } & \multicolumn{2}{|c|}{ Exports } & \multicolumn{2}{|c|}{ Imports + Exports } \\
\hline & Model 1 & Model 2 & Model 1 & Model 2 & Model 1 & Model 2 \\
\hline & $\begin{array}{l}\text { Random } \\
\text { effects }\end{array}$ & $\begin{array}{l}\text { Fixed } \\
\text { effects }\end{array}$ & $\begin{array}{l}\text { Fixed } \\
\text { effects }\end{array}$ & $\begin{array}{l}\text { Random } \\
\text { effects }\end{array}$ & $\begin{array}{l}\text { Fixed } \\
\text { effects }\end{array}$ & $\begin{array}{l}\text { Random } \\
\text { effects }\end{array}$ \\
\hline \multirow[t]{2}{*}{ size } & $0.720 * * *$ & $0.887 * * *$ & $0.752 * * *$ & $0.921 * * *$ & $0.678 * * *$ & $0.896 * * *$ \\
\hline & $(0.056)$ & $(0.135)$ & $(0.105)$ & $(0.105)$ & $(0.057)$ & $(0.061)$ \\
\hline \multirow[t]{2}{*}{ dist } & -0.341 & & & $-3.072 * * *$ & & $-0.836 * * *$ \\
\hline & $(0.241)$ & & & $(0.356)$ & & $(0.177)$ \\
\hline \multirow[t]{2}{*}{ border } & $1.231 * *$ & & & 0.002 & & $0.811 * * *$ \\
\hline & $(0.542)$ & & & $(0.435)$ & & $(0.299)$ \\
\hline \multirow[t]{2}{*}{ endow } & -0.238 & -0.061 & -0.452 & $0.633 * * *$ & -0.087 & 0.072 \\
\hline & $(0.184)$ & $(0.302)$ & $(0.358)$ & $(0.204)$ & $(0.200)$ & $(0.078)$ \\
\hline \multirow[t]{2}{*}{ ssize } & 0.101 & 0.319 & 0.482 & $-0.284 *$ & 0.307 & 0.106 \\
\hline & $(0.127)$ & $(0.348)$ & $(0.320)$ & $(0.164)$ & $(0.206)$ & $(0.103)$ \\
\hline \multirow[t]{2}{*}{ infra } & & $0.635 *$ & & $1.827 * * *$ & & $0.601 * * *$ \\
\hline & & $(0.388)$ & & $(0.331)$ & & $(0.187)$ \\
\hline \multirow[t]{2}{*}{ instit } & & 0.088 & & $0.359 * * *$ & & $0.252 * * *$ \\
\hline & & $(0.101)$ & & $(0.119)$ & & $(0.083)$ \\
\hline \multirow[t]{2}{*}{ yugo } & & & & $1.639 * * *$ & & $1.908 * * *$ \\
\hline & & & & $(0.409)$ & & $(0.317)$ \\
\hline \multirow[t]{2}{*}{ saa } & & -0.067 & & 0.064 & & -0.008 \\
\hline & & $(0.119)$ & & $(0.198)$ & & $(0.103)$ \\
\hline \multirow[t]{2}{*}{$f d i$} & & $-0.240 *$ & & -0.013 & & $-0.172 * *$ \\
\hline & & $(0.143)$ & & $(0.149)$ & & $(0.082)$ \\
\hline \multirow[t]{2}{*}{ exch } & & $-0.662 * *$ & & 0.076 & & 0.006 \\
\hline & & $(0.307)$ & & $(0.067)$ & & $(0.048)$ \\
\hline \multirow[t]{2}{*}{ const } & $-17.96 * * *$ & $-27.93 * * *$ & $-21.78 * * *$ & $-18.83 * * *$ & $-16.92 * * *$ & $-24.85 * * *$ \\
\hline & $(2.832)$ & (7.339) & $(5.760)$ & $(3.581)$ & (3.249) & $(2.673)$ \\
\hline $\begin{array}{l}\text { Num. of } \\
\text { obser. }\end{array}$ & 374 & 352 & 351 & 329 & 378 & 355 \\
\hline Adj. $R^{2}$ & 0.5022 & 0.5008 & 0.3629 & 0.7195 & 0.5391 & 0.7395 \\
\hline Hausman & 4.72 & 16.23 & 20.10 & 11.70 & 8.57 & 13.38 \\
\hline Test & 0.1936 & 0.0392 & 0.0002 & 0.1653 & 0.0357 & 0.0995 \\
\hline
\end{tabular}


Table A.5. Estimation results for final goods trade with country-pair fixed effects

\begin{tabular}{|c|c|c|c|c|c|c|}
\hline & \multicolumn{6}{|c|}{ Final goods } \\
\hline & \multicolumn{2}{|c|}{ Imports } & \multicolumn{2}{|c|}{ Exports } & \multicolumn{2}{|c|}{ Imports + Exports } \\
\hline & Model 1 & Model 2 & Model 1 & Model 2 & Model 1 & Model 2 \\
\hline & $\begin{array}{l}\text { Random } \\
\text { effects }\end{array}$ & $\begin{array}{l}\text { Fixed } \\
\text { effects }\end{array}$ & Fixed effects & $\begin{array}{l}\text { Fixed } \\
\text { effects }\end{array}$ & $\begin{array}{l}\text { Random } \\
\text { effects }\end{array}$ & $\begin{array}{l}\text { Fixed } \\
\text { effects }\end{array}$ \\
\hline \multirow[t]{2}{*}{ size } & $0.801 * * *$ & $0.875 * * *$ & $0.823 * * *$ & $1.027 * * *$ & $0.767 * * *$ & $0.803 * * *$ \\
\hline & $(0.064)$ & $(0.130)$ & $(0.117)$ & $(0.227)$ & $(0.060)$ & $(0.107)$ \\
\hline \multirow[t]{2}{*}{ dist } & $-0.703 * * *$ & & & & $-0.885 * * *$ & \\
\hline & $(0.236)$ & & & & $(0.231)$ & \\
\hline \multirow[t]{2}{*}{ border } & $0.877 * *$ & & & & $1.012 * * *$ & \\
\hline & $(0.424)$ & & & & $(0.375)$ & \\
\hline \multirow[t]{2}{*}{ endow } & 0.048 & -0.338 & -0.442 & $-0.654 * *$ & 0.194 & -0.361 \\
\hline & $(0.184)$ & $(0.336)$ & $(0.363)$ & $(0.278)$ & $(0.146)$ & $(0.340)$ \\
\hline \multirow[t]{2}{*}{ ssize } & -0.072 & 0.001 & 0.135 & 1.028 & -0.121 & 0.020 \\
\hline & $(0.122)$ & $(0.230)$ & $(0.462)$ & $(0.677)$ & $(0.123)$ & $(0.214)$ \\
\hline \multirow[t]{2}{*}{ infra } & & $0.897 * * *$ & & $1.307 * * *$ & & $0.728 * * *$ \\
\hline & & $(0.270)$ & & $(0.426)$ & & $(0.202)$ \\
\hline \multirow[t]{2}{*}{ instit } & & 0.119 & & $0.284 * *$ & & $0.135 * *$ \\
\hline & & $(0.088)$ & & $(0.122)$ & & $(0.061)$ \\
\hline \multicolumn{7}{|l|}{ yugo } \\
\hline \multirow[t]{2}{*}{ saa } & & -0.110 & & 0.121 & & -0.082 \\
\hline & & $(0.113)$ & & $(0.198)$ & & $(0.091)$ \\
\hline \multirow[t]{2}{*}{$f d i$} & & $-0.213 *$ & & -0.292 & & -0.129 \\
\hline & & $(0.124)$ & & $(0.234)$ & & $(0.107)$ \\
\hline \multirow[t]{2}{*}{ exch } & & -0.392 & & $0.802 *$ & & $-0.483 * *$ \\
\hline & & $(0.368)$ & & $(0.429)$ & & $(0.246)$ \\
\hline \multirow[t]{2}{*}{ const } & $-18.18 * * *$ & $-27.55 * * *$ & $-24.72 * * *$ & $-37.37 * * *$ & $-15.07 * * *$ & $-23.16 * * *$ \\
\hline & $(2.783)$ & (6.669) & (6.889) & (11.130) & (2.438) & (5.464) \\
\hline $\begin{array}{l}\text { Num. of } \\
\text { obser. }\end{array}$ & 379 & 356 & 366 & 343 & 379 & 356 \\
\hline Adj. $R^{2}$ & 0.5952 & 0.5796 & 0.4045 & 0.4576 & 0.5928 & 0.6382 \\
\hline Hausman & 6.19 & 18.95 & 10.71 & 18.47 & 4.37 & 21.50 \\
\hline Test & 0.1026 & 0.0151 & 0.0134 & 0.0180 & 0.2243 & 0.0059 \\
\hline
\end{tabular}




\title{
Chapter II
}

International Production Networks and Economic Growth: The Case of the Western Balkan Countries

\begin{abstract}
The recent economic modernization and increasing openness of the Western Balkan countries (WBC) has led to a significant expansion of processing trade in these economies. This phenomenon has enabled countries to undergo a more in-depth specialization in niche parts of the production chain, with important benefits for their economic activity and growth. The purpose of this work is to analyze the impact that the different degree of participation in international production networks has on the economic performance of the WBC. In doing so, we test the hypothesis that trade created by international fragmentation of production may generate effects on economic growth beyond the beneficial influence of total or final goods trade. Given the availability of data, we focus on the period 2002-2013. The results, using a set of panel data models, show that the degree of involvement in IPN significantly affects the economic performance of the WBC, which partly explains the observed differences in their growth rates. We also find that the positive influence of processing trade on economic growth are over the traditional gains of an increase in foreign demand.
\end{abstract}

JEL classifications: C33; F14; F15

Key words: International production networks, Inward processing trade, Western Balkan countries, Economic growth, Panel data models 


\subsection{Introduction}

As a consequence of the increasing globalization and integration of the world's markets, there has been an intensive process of international fragmentation of the production over the last few decades ${ }^{24}$. This phenomenon, whereby productive activities are segmented into several stages taking place in different countries, allows firms to select the bestsuited locations in terms of factor endowments, scale or productivities for each stage. Multinational firms may thus adopt more complex strategies involving exports of intermediate goods to and from third countries and intra-firm trade. According to a recent report, intermediate products trade reached more than US\$ 7 trillion in 2011, accounting for around forty percent of the total world trade. Moreover, this type of trade has been increasingly important for developing countries, as their share has experienced constant growth over the past decade (UNCTAD 2013).

As Athukorala and Yamashita (2006) mention, the international division of the production process may give a country a comparative advantage in one or more production stages even when the country is not the most efficient producer of the final good. Greater participation in international production networks might therefore have important implications for a country's trade pattern and economic behavior. In this process, the Western Balkan countries, comprising Albania, Bosnia and Herzegovina, Croatia, Macedonia, Montenegro and Serbia, have proven to be no exception ${ }^{25}$. Recent economic modernization and increasing openness of the WBC has led to a significant expansion of processing trade in these economies (Eurostat, 2014). This chapter examines precisely the impact this phenomenon has on their economic performance.

Increased sophistication of production, declining service link costs and foreign direct investment by multinational enterprises have been the main driving forces for reorganizing the production process in a setting of increasing competition and economic growth. Firms are constantly exposed to new opportunities for cutting costs and improving productivity by adapting their strategies to new business models through innovation, technological spillovers and catch-up. Likewise, the comparative

\footnotetext{
24 The same process has been labeled differently by different authors. For example, slicing up the value chain (Krugman 1995), outsourcing (Feenstra and Hanson 1997), disintegration of production (Feenstra 1998), intra-product specialization (Arndt 1997), vertical specialization (Hummels et al. 2001) or fragmentation (Jones and Kierzkowski 1990; Deardorff 2001).

${ }^{25}$ Kosovo was not included in the study because of data limitations.
} 
advantages of the countries in which they operate also undergo continuous change (Mudambi and Venzin 2010). A highly-integrated world economy thus creates new opportunities from cross-country differences, which results in a process where each country specializes in a particular stage of the production process, and where intermediate and capital goods are actively traded (Arndt 1997; Jones and Kierzkowski 1990, 2001; Deardorff 1998, 2001). This increased trade in intermediate and capital goods leads to increased output and economic growth, as indicated by Baldone et al. (2007) and Foster et al. (2013). According to these authors, integration in IPN allows countries to achieve better economic performance.

Following the fall of the former Soviet Union and the consequent events in Eastern European countries in the early 1990's, the WBC began a process of economic transition to replace their former planned economic systems with market economies and renewing trade integration both within the region and with the world (especially the EU). The WBC embarked on extensive reform programs that pursued aims such as liberalization, stabilization and privatization. They opened up to global trade and became increasingly export-oriented, expanded the role of the private sector, dismantled regulations that stifled business development and began to build institutions needed to support a market system (IMF 2015) ${ }^{26}$. Under a European Union initiative to promote political stability and economic growth, new institutional arrangements were created to deliver this policy agenda: the Stability Pact for South East Europe and the Stabilization and Association Process ${ }^{27}$. The cooperation was further enhanced with the extension of the Central European Free Trade Agreement to the Western Balkans in December 2006 and the beginning of accession negotiations with the EU by most of the $\mathrm{WBC}^{28}$.

The general purpose of these measures was to build a business-friendly environment with minimal disruption to transport and communication between production segments,

\footnotetext{
26 Barriers to trade including non-tariff barriers were removed and customs systems and legal practices were aligned with those in the EU. The trade and transport facilitation program for South Eastern Europe helped customs reforms and improved coordination between border control agencies, as well as eliminating bottlenecks at border crossings in the region.

27 At the same time as the Stabilisation and Association Process was launched, the EU granted a comprehensive set of Autonomous Trade Preferences to the Western Balkan countries. These provided for a unilateral dismantling of import tariffs and duties for almost all goods emanating from the Western Balkan countries.

${ }^{28}$ Out of the six countries, Croatia became a member of EU in July 2013; Serbia and Montenegro are in the accession negotiating process; Albania and Macedonia are in the status of EU candidate countries; while Bosnia and Herzegovina is considered a potential candidate country.
} 
allowing the WBC a chance to integrate into the pattern of international productive specialization. This economic transformation resulted in a significant increase in both economic growth and processing trade. According to the IMF (2015), the results of the transition process was strong economic growth, a significant rise in incomes and living standards and enhanced macroeconomic stability. Moreover, during this period, the rise of trade in parts and components in these countries outpaced the rate of increase in final goods trade, with the former growing at more than twice the rate of the latter (see Shimbov et al. 2013, p. 373, for more detail). The WBC have thus become more integrated into the production-sharing networks, especially with the European Union, which accounted for more than eighty percent of the overall processing trade exports of the region. Nevertheless, to the best of our knowledge, the impact of this integration process on output growth in these countries has yet to be examined.

In this chapter, we try to fill this gap by analyzing the links between the increasing internationalization of production and the economic performance of the WBC. In doing so, we elaborate an index that captures the involvement of the different WBC in the process of international fragmentation of production. This allows us to evaluate more precisely the specific effects of this phenomenon on economic growth divergences and to test the hypothesis that the degrees of involvement in international production networks influence the economic performance of the $\mathrm{WBC}$, even once the beneficial influence of final goods trade is taken into account. Our results suggest that the international division of production has a significant and positive effect on economic growth. More precisely, we find that the diverse economic growth paths among WBC may be partly explained by their different degree of participation in the international production network.

The rest of the chapter is organized as follows. Section 2 provides a brief overview of the literature analyzing the links between participation in IPN and the related impact on economic growth. Section 3 contains some relevant stylized facts on this ongoing process of international fragmentation of production in the WBC. We present several indicators to show the scope and the distribution (in both geographical and industrial terms) of processing trade and to reveal similarities and differences across the WBC in this respect. The econometric specification and estimation results are presented in Section 4. The final section concludes with a policy discussion and suggestions for future developments on the topic. 


\subsection{Related literature}

It is a well-known fact that international trade is not limited to situations in which each partner country is specialized in products from different industries, as explained by traditional comparative advantage theories based on relative endowments or technological differences. These traditional models of inter-industry trade flows between developing and developed economies neglect, however, the international fragmentation of the production and therefore the shipment of intermediate goods between countries. To properly understand the growing share of trade in intermediate goods within the same industry occurring even between countries with similar levels of development, and the consequent implications for their economies, we need to rely on other theories that take into account the division of the production process across countries.

The publication of the seminal work by Grubel and Lloyd (1975) and the developments of the "new" trade theory, which introduced scale economies and product varieties, shed new light on the notion that different products within the same industry are produced and traded by different countries, giving rise to intra-industry trade (IIT). The understanding of this type of trade was further formalized in theoretical terms by Krugman (1980) and Helpman and Krugman (1985), who provided seminal contributions along the lines of Dixit and Stiglitz (1977). According to these models, trade flows between industrialized countries should not be characterized by comparative advantages. On the contrary, the exchange of homogeneous goods (horizontal IIT) is driven by imperfect competition and variety preferences. However, these early models do not fully explain international trade flows in intermediate and unfinished goods that result from the IPN. This type of trade seems to be better explained by the literature on vertical IIT $^{29}$ and international production networks (or global value chains -GVCs). According to this literature, international production, trade and investments are increasingly organized within the so-called global value chains where the different stages of the production process are located across different countries ${ }^{30}$.

\footnotetext{
${ }^{29}$ Vertical IIT is defined as the simultaneous exporting and importing of products in the same industry but at different stages of production.

30 A theoretical framework for the value chain analysis has been recently provided by Gereffi et al. (2005).
} 
The first general framework to analyze the international fragmentation of the production process was introduced by Jones and Kierzkowski $(1990)^{31}$. They argued that by segmenting the production into several stages, firms have an opportunity to match and optimize the different factor endowments and productivities with the specific requirements of each production stage. Thus, the process of international fragmentation of production implies that a certain product may not be entirely produced in one country and then exported as final good to another country. Rather, it is likely that the production process and consequently the final product will be characterized by an increasing share of inputs from other countries and by offshoring parts of the production, allowing firms to specialize in niche parts of the production (value) chain. International production networks allow so for a more in-depth specialization to take place within a single industry or product, and for increasing trade in intermediate goods (Deardorff 1998, 2001). Feenstra (1998) takes this idea one step further by explicitly connecting the "integration of trade" with the "disintegration of production" in the global economy. This has led to a growing proportion of international trade occurring in components and other intermediate goods (Yeats, 2001, WTO 2011). For Baldwin (2014) goods are packages of a many nations's productive factors, technology, social capital, and governance capacity. The rising internationalization of production may therefore have important implications for a country's trade and output growth facilitating technology dissemination, skills building and industrial upgrading (Geraffi, 1999; Baldwin, 2014).

Several theoretical papers have emphasized the importance of intermediate goods trade for output growth. Feenstra (1998), for instance, argues that over and above the traditional gains from increased specialization and exchange across countries, trade in intermediate inputs brings efficiency gains that amount to an outward shift in the production frontier for final goods in each country. In a seminal work, Samuelson (2001) developed a Ricardian model of international trade in which each of two final goods could be used as an intermediate good in the production of the other good. The model shows that international trade results in a much larger expansion of output than would otherwise be obtained if goods could not be used as intermediate inputs. This model was further extended by Shiozawa (2007), with a multi-country and multi-

\footnotetext{
31 Other important contributions to the theory of fragmentation can be found in Arndt (1997), Arndt and Kierzkowski (2001), Jones and Kierzkowski (2001) and Deardorff (1998, 2001).
} 
commodity study, obtaining similar findings. More recently, Ramondo and RodríguezClare (2009) in a multi-country general-equilibrium Ricardian model confirm this outcome showing that the gains from trade including multinational production has a positive effect on expanding output and growth, much greater than those obtained if only trade in final goods is considered. For Jones (2011), intermediate goods provide links between sectors that create a multiplier effect similar to the one associated with capital accumulation in neoclassical growth models. According to his model, the intermediate goods share used in the economy is a crucial parameter that enables a country to achieve a substantially larger output and income, thus helping to explain differences in economic performance across countries.

These theoretical developments have been also accompanied by empirical works that in general confirm the growth enhancing role of the international fragmentation of production $^{32}$. For instance, using a panel data approach, Egger et al. (2001) find that outsourcing to the East, by Austrian manufacturing firms, significantly improves domestic growth and productivity in the origin country. For Helg and Tajoli (2005) it is not only trade flows that is affected by the international fragmentation of production, but that the industries involved may also increase their total output and productivity due to growth in the relative demand for the abundant factor. Similarly, Amiti and Wei (2009) find that services offshoring has a positive impact on manufacturing industries productivity in the US. According to Baldone et al. (2007), participating in IPN is a powerful contributor to growth, complementing the impact generated by final goods trade. This is also confirmed by Foster et al. (2013) who analyze the effects of international fragmentation on forty advanced and emerging economies. For Miroudot et al. (2009) and Goldberg et al. (2010), the access to a range of competitively priced foreign intermediate goods has been crucial to achieving higher productivity and output growth in both OECD and emerging countries. In this line, OECD calculations show that most world regions, including both developed and emerging economies, have increased the value added they create and capture in GVCs of manufactured goods (OECD 2013). Another stream of the literature had also focused on the social benefits

\footnotetext{
${ }^{32}$ Three main data sources and methodological approaches have been used in empirical works to measure the scope and impact of international fragmentation of production and GVCs: (i) trade in parts and components; (ii) customs statistics on processing trade and; (iii) a relatively new line of research involving global Input-Output matrices and trade in value-added. General findings from these works are that intermediate goods trade had been expanding faster than trade in finished goods and that fragmentation trade and participation in GVCs is a powerful driver of growth.
} 
and upgrading from international fragmentation of production and participation in IPN that together with the above mentioned economic upgrading contribute towards more sustainable growth and development (Barrientos et al. 2011) ${ }^{3334}$.

Nevertheless, to the best of our knowledge, the effects of participation in IPN and processing trade on growth performance has never been empirically tested for the WBC. Thus, in an effort to shed more light on this subject, in the remaining part of the chapter we will empirically investigate the influence that this form of international division of production has on the economic activity of the WBC.

\subsection{Data and Stylized facts}

To empirically analyze the role played by international fragmentation of production in the WBC, we employ data on processing trade (that is, information about trade in goods that are exported or imported for reasons of processing). We include the following countries of the Western Balkan region: Albania, Bosnia and Herzegovina, Croatia, Macedonia, Montenegro and Serbia ${ }^{35}$. The analysis of the processing trade is based on their bilateral trade relations with the rest of the world. Specifically, we use data collected by Eurostat for the following four trade flows: i) imports of goods for processing in a Western Balkan country, coming from another country; ii) the consequent exports of the processed goods to the country of origin; iii) exports of goods for processing from a Western Balkan country; and iv) the resulting imports of the processed goods by the Western Balkan country. The first two flows represent the socalled inward processing trade (IPT), while the latter two are defined as outward processing trade (OPT). Thus, this dataset allows us the possibility of assessing each country's relative position in the production chain both as a receiver and a source of processing trade, and also enables to see the importance of this kind of trade across sectors.

\footnotetext{
33 According to Locke et al. (2007) and Rossi (2011) economic upgrading can result in social upgrading, but this does not happen automatically and in all cases.

34 The authors are thankful to an anonymous referee for pointing out this important part of the implications of international fragmentation of trade and participation in IPN.

${ }^{35}$ We include Montenegro and Serbia together given that they formed one country during half of the analyzed period.
} 


\subsubsection{Scope and distribution of processing trade in the Western Balkan countries}

Table 1 below shows the relevance of IPT and OPT flows in the WBC during the period 2002-2013. On the one hand, these figures clearly show that the WBC are far more likely to be a destination of processing trade than a source of this kind of trade, as can be seen by the significantly greater weight of IPT compared to OPT with respect to final goods $\operatorname{trade}^{36}$. Moreover, this tendency remains largely similar throughout the analyzed period, with a minor decline during the period 2010-2012 as a result of the international economic crises, before rebounding in $2013^{37}$. It is also worth noting that IPT exports have represented more than forty percent of the corresponding amount of final trade exports every year, with rates exceeding one hundred percent in the first years of the sample period ${ }^{38}$. This reveals the importance of this type of trade for these countries.

Additionally, looking in this table at the difference between IPT imports and their consequent exports (which represents the value added in the country by processing the goods), we observe that this gap has increased significantly over time. In fact, it has more than doubled in the observed period, reaching more than 3 percent of GDP in recent years. This provides an additional insight into the relevance of this trade for the WBC economies.

On the contrary, the above figures show a much lower weight of OPT compared to final goods trade than IPT. Furthermore, we observe a constant decline over the past decade, reaching historic lows in the last three years. This may be a consequence of the relatively low level of technological complementarity that exists between the WBC and their main partner, the EU (which accounts for two-thirds of total OPT on average over the analyzed period in this area). As indicated by Görg (2000), OPT usually plays a more significant role when there are technological similarities between trading partners, especially in relatively more knowledge intensive industries. For that reason, in the empirical analysis that follows we consider IPT exports as representative of processing trade.

\footnotetext{
${ }^{36}$ However, as an anonymous referee mentioned, we should be conscious that there is a part of final goods trade that can be inbounds of processing trade. This is especially true in the automobile assembly activity of multinational firms (especially important in Serbia and Croatia).

37 This agrees with findings by Los et al. (2015) who show that international fragmentation trade flows have resumed quickly after the 2009 crises, with emerging economies playing a growing role as suppliers of intermediate goods.

38 These figures might be explained by the high amount of processing trade in apparel, textile and leather, especially in Albania, but also in Croatia and Macedonia.
} 
Table 1. Processing and final goods trade in the Western Balkan countries: 2002-2013

\begin{tabular}{|c|c|c|c|c|c|c|c|c|c|c|c|c|}
\hline & 2002 & 2003 & 2004 & 2005 & 2006 & 2007 & 2008 & 2009 & 2010 & 2011 & 2012 & 2013 \\
\hline \multicolumn{13}{|c|}{ Inward Processing Trade (in mill. EUR) } \\
\hline Imports & 2,084 & 2,221 & 2,268 & 2,881 & 3,404 & 3,973 & 5,501 & 3,882 & 4,328 & 4,016 & 4,310 & 3,687 \\
\hline \multicolumn{13}{|c|}{ as \% over the corresponding final goods trade flow } \\
\hline Imports & 16.63 & 16.34 & 15.26 & 11.39 & 11.35 & 10.85 & 11.13 & 10.50 & 11.12 & 9.96 & 9.95 & 10.97 \\
\hline Exports & 141.41 & 111.29 & 91.13 & 53.77 & 48.77 & 47.07 & 51.17 & 49.92 & 44.67 & 41.86 & 41.77 & 46.49 \\
\hline \multicolumn{13}{|c|}{ Outward Processing Trade (in mill. EUR) } \\
\hline Imports & 40 & 35 & 30 & 69 & 83 & 83 & 151 & 94 & 94 & 118 & 109 & 83 \\
\hline Exports & 133 & 302 & 241 & 257 & 363 & 456 & 596 & 166 & 213 & 98 & 101 & 96 \\
\hline \multicolumn{13}{|c|}{ as \% over the corresponding final goods trade flow } \\
\hline Exports & 5.49 & 10.39 & 6.37 & 3.46 & 3.71 & 3.72 & 4.05 & 1.37 & 1.35 & 0.56 & 0.54 & 0.63 \\
\hline \multicolumn{13}{|c|}{ Final Goods Trade (in mill. EUR) } \\
\hline Imports & 12,528 & 13,596 & 14,860 & 25,291 & 29,990 & 36,602 & 49,406 & 36,968 & 38,917 & 40,304 & 43,331 & 33,609 \\
\hline Exports & 2,428 & 2,908 & 3,787 & 7,446 & 9,803 & 12,241 & 14,719 & 12,120 & 15,775 & 17,583 & 18,651 & 15,253 \\
\hline
\end{tabular}

Source: author's calculations based on Eurostat Comext database. 
Table 2. Geographical structure of the WBC inward processing trade exports

\begin{tabular}{|c|c|c|c|c|c|c|c|c|c|c|c|c|}
\hline & 2002 & 2003 & 2004 & 2005 & 2006 & 2007 & 2008 & 2009 & 2010 & 2011 & 2012 & 2013 \\
\hline \multicolumn{13}{|l|}{ processing trade in mill. EUR } \\
\hline EU-27 & 2,798 & 2,688 & 2,889 & 3,362 & 3,960 & 4,468 & 5,909 & 4,907 & 5,590 & 5,508 & 5,909 & 5,944 \\
\hline Other Europe & 333 & 282 & 239 & 296 & 443 & 678 & 1,042 & 709 & 828 & 1,129 & 1,011 & 734 \\
\hline North America & 135 & 139 & 162 & 192 & 184 & 183 & 239 & 98 & 79 & 63 & 121 & 49 \\
\hline North Africa & 10 & 11 & 10 & 13 & 24 & 20 & 32 & 36 & 47 & 38 & 25 & 38 \\
\hline Central and South America & 72 & 11 & 75 & 42 & 40 & 158 & 69 & 49 & 217 & 196 & 187 & 15 \\
\hline Near and Middle Eastern countries & 33 & 23 & 30 & 51 & 63 & 134 & 73 & 83 & 106 & 77 & 100 & 37 \\
\hline Other Asian countries & 52 & 82 & 47 & 47 & 66 & 122 & 166 & 167 & 180 & 350 & 437 & 275 \\
\hline \multicolumn{13}{|l|}{ as $\%$ of total processing trade } \\
\hline EU-27 & 81.5 & 83.1 & 83.7 & 84.0 & 82.8 & 77.5 & 78.5 & 81.1 & 79.3 & 74.8 & 75.9 & 83.8 \\
\hline Other Europe & 9.7 & 8.7 & 6.9 & 7.4 & 9.3 & 11.8 & 13.8 & 11.7 & 11.7 & 15.3 & 13.0 & 10.4 \\
\hline North America & 3.9 & 4.3 & 4.7 & 4.8 & 3.9 & 3.2 & 3.2 & 1.6 & 1.1 & 0.9 & 1.6 & 0.7 \\
\hline North Africa & 0.3 & 0.3 & 0.3 & 0.3 & 0.5 & 0.3 & 0.4 & 0.6 & 0.7 & 0.5 & 0.3 & 0.5 \\
\hline Central and South America & 2.1 & 0.3 & 2.2 & 1.0 & 0.8 & 2.7 & 0.9 & 0.8 & 3.1 & 2.7 & 2.4 & 0.2 \\
\hline Near and Middle Eastern countries & 1.0 & 0.7 & 0.9 & 1.3 & 1.3 & 2.3 & 1.0 & 1.4 & 1.5 & 1.0 & 1.3 & 0.5 \\
\hline Other Asian countries & 1.5 & 2.5 & 1.4 & 1.2 & 1.4 & 2.1 & 2.2 & 2.8 & 2.6 & 4.8 & 5.6 & 3.9 \\
\hline
\end{tabular}

Source: author's calculations based on Eurostat Comext database. 
Table 2 gives a detailed picture of the geographical distribution of the processing trade in the WBC. As can be seen, EU countries are by far the most important destination and source of processing trade, with Germany and Italy being the main trading partners accounting for around half of all processing trade with the EU. Throughout the analyzed period, the EU accounted on average for more than eighty percent of this type of trade. The second most important destination and origin of processing trade in the WBC is represented by other European countries, with percentages around ten percent during the last years of the considered period. The same distributional pattern is maintained in general when we look at the individual countries of the Western Balkans ${ }^{39}$.

Figure 1. Industrial structure of the WBC inward processing trade exports, as $\%$ of total trade in the category: 2002-2013.

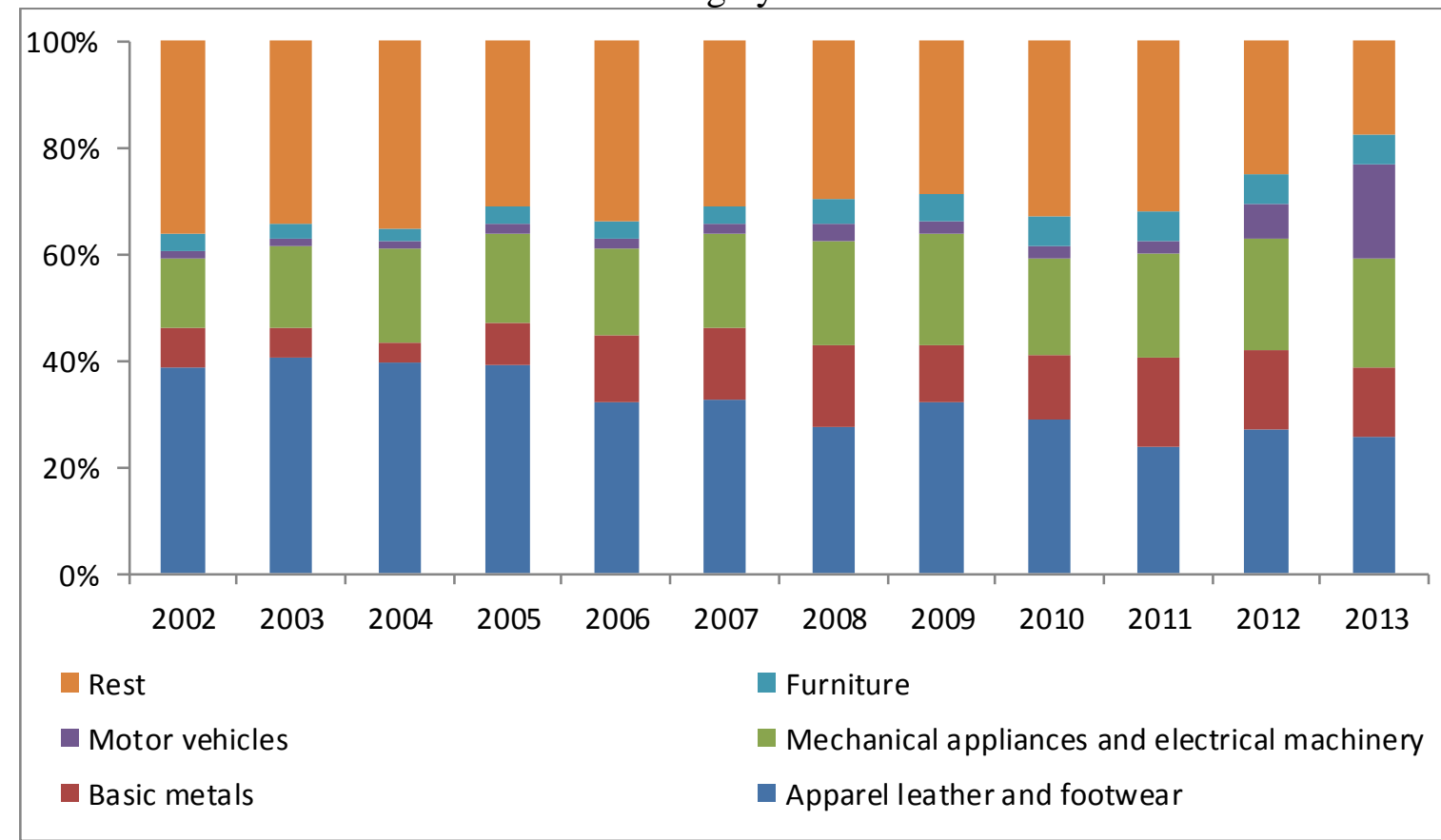

Source: author's calculations based on Eurostat Comext database.

Similar concentration is observed in the industrial structure of processing trade of the WBC. Figure 1 shows that processing trade in the WBC largely centers on apparel, basic metals, electrical and mechanical machinery and more recently, to a certain extent on furniture and motor vehicles. Nevertheless, it can be seen that the WBC which started with a relatively high share of low value added industries (such as apparel, leather and footwear), managed to increase their share of processing trade in higher value-added industries over the years, giving them the possibility of reinforcing sharing of know-how, productivity and output, as indicated by Stehrer and Wörz (2009). Behind

\footnotetext{
${ }^{39}$ Data are available on request.
} 
this shift are the multinational firms that located part of their production chain in the region and were basically represented by industries such as electrical machinery, machinery and mechanical appliances, and motor vehicles. At the level of individual countries, we observe that the biggest shift in the industrial structure occurred in Serbia and Montenegro, where there was an approximately fourfold decrease in the share of apparel, while at the same time the share of higher value-added industries such as electrical machinery, motor vehicles and rubber products, increased. Macedonia and Croatia also experienced a rise in the share of industries such as basic metals in the former, and machinery and mechanical appliances in the latter (Eurostat, 2014).

These stylized facts clearly show three important features about processing trade in the WBC. First, these countries are a far more important destination of processing trade than a source of this kind of trade. Second, processing trade in these economies has increased significantly over the past years, with the EU being by far the most important trading partner. Finally, we observe a positive structural shift towards relatively higher value-added industries. In order to properly understand the relevance of these facts in terms of the economic behavior of the $\mathrm{WBC}$, we need to look more closely at their capability of participating in the production-sharing networks.

\subsubsection{Measuring the participation in processing trade}

With the aim of analyzing the impact that the involvement in the IPN has on the WBC, following Baldone et al. (2007), we elaborate an index that captures the relative tendency of each country to participate in this process. This index is defined as,

$$
I I F_{i j}=\left(P T_{i j} / F T_{i j}\right) /\left(P T_{W B C, j} / F T_{W B C, j}\right)
$$

where $I I F_{i j}$ is the index of international fragmentation ( $i$ and $j$ refers to the corresponding country and trade flows i.e. exports or imports, respectively); FT represents final trade flows, and $P T$ measures processing trade. This index captures the tendency of a country to participate in processing trade, using the average WBC level as a benchmark.

The IIF is in fact a country-specific Balassa-type revealed comparative advantages index in which the emphasis is on measuring the fragmentation in production for a given Western Balkan country. The index as it is defined shows, however, a biased 
range. Values higher than one express levels of fragmentation above the regional (WBC) average, whereas the opposite is true for values between one and zero. The nonsymmetric outcome of the results from the calculation introduces an evident difficulty when interpreting this index. This methodological shortcoming can be overcome by using a logarithmic conversion $\left(\log I I F_{i j}\right)$. The resulting range of values will be symmetric: positive when the country has a comparative propensity to undertake processing trade and negative if the reverse is true. Furthermore, index values which are the same, but with a different signs can be understood as equivalent, but opposite behavior in terms of a fragmented production and trade specialization.

Table 3. Index of international fragmentation (in log) for the WBC: 2002-2013

\begin{tabular}{|c|c|c|c|c|c|c|c|c|c|c|c|c|}
\hline & 2002 & 2003 & 2004 & 2005 & 2006 & 2007 & 2008 & 2009 & 2010 & 2011 & 2012 & 2013 \\
\hline Albania & 0.78 & 1.20 & 1.44 & 1.48 & 1.66 & 1.46 & 0.54 & 1.24 & 0.95 & 0.73 & 0.58 & 0.36 \\
\hline $\begin{array}{l}\text { Bosnia and } \\
\text { Herzegovina }\end{array}$ & & & & & & & 0.72 & 0.47 & 0.54 & 0.47 & 0.46 & 0.31 \\
\hline Croatia & -0.05 & -0.11 & -0.10 & 0.26 & 0.17 & 0.10 & -0.06 & -0.08 & 0.09 & 0.04 & -0.18 & -0.48 \\
\hline Macedonia & 0.01 & 0.11 & 0.01 & 0.26 & 0.08 & -0.07 & -0.03 & 0.06 & -0.40 & -0.17 & -0.13 & -0.28 \\
\hline $\begin{array}{l}\text { Serbia and } \\
\text { Montenegro }\end{array}$ & & & & -1.03 & -0.53 & -0.30 & -0.34 & -0.36 & -0.47 & -0.38 & -0.10 & 0.09 \\
\hline
\end{tabular}

Source: author's calculations based on Eurostat Comext database.

As can be observed in Table 3, although most WBC have a comparative propensity to undertake processing trade, there are noticeable differences between individual countries. Albania and Bosnia-Herzegovina, for instance, are the only two countries that managed to maintain a higher propensity to participate in the IPN throughout the analyzed period (even though the period for Bosnia and Herzegovina is shorter), yet we observe a gradual decline of the index values over the years. A similar decrease can be observed in Macedonia's index over the analyzed period, but contrary to Albania and Bosnia-Herzegovina, the index turns negative in the last years of the sample. Croatia's index varies from year to year, but it also clearly declines in the last few years. Finally, the index of Serbia and Montenegro rose significantly and rapidly caught-up to that of the other countries, showing an increasing differential-trend with respect to other WBC.

Next, in order to shed more light on the higher relevance of some industries compared to others (such as shown by the previous sectorial distribution analysis of IPT exports), we look at the industrial distribution of the index of international fragmentation among 
the WBC. From Table 4 below, we observe a common pattern of having a comparative advantage in the production of textile, apparel and leather and footwear (with the exception of Serbia and Montenegro). Apart from this, each county appears to have specialized in different industries, although with a gradual shift towards industries with higher value-added ${ }^{40}$.

In short, the above discussion reveals that processing trade plays an increasingly important role in the $\mathrm{WBC}$, especially in recent years (when the value added of trade in these economies has increased significantly). However, in terms of their comparative propensity to undertake processing trade there are significant differences across countries during the analyzed period. Accordingly, a natural extension is to establish the extent to which their participation in IPN affects the growth performance of these countries.

\footnotetext{
${ }^{40}$ Further extension of this analysis should concentrate on a sectoral approach to the phenomenon we are studying here. Productive specialization logically implies different patterns of processing trade for specific sectors or products.
} 
Table 4. Indexes of international fragmentation per industries.

\begin{tabular}{|c|c|c|c|c|c|c|c|c|c|c|c|c|}
\hline & 2002 & 2003 & 2004 & 2005 & 2006 & 2007 & 2008 & 2009 & 2010 & 2011 & 2012 & 2013 \\
\hline \multicolumn{13}{|l|}{ Albania } \\
\hline Food products & -3.86 & 0.40 & 0.20 & 1.02 & 0.93 & 1.27 & 1.32 & 1.90 & 2.14 & 2.04 & 1.90 & 2.01 \\
\hline Textile & -0.55 & 1.09 & 1.19 & 1.23 & 2.23 & 2.02 & 0.56 & 1.91 & 2.60 & 2.35 & 1.72 & 1.39 \\
\hline Apparel & 1.08 & 1.61 & 1.66 & 0.50 & 2.34 & 2.94 & 1.54 & 2.74 & 3.14 & 3.62 & 3.84 & 3.70 \\
\hline Leather and footwear & 0.35 & 1.40 & 1.74 & 1.10 & -1.98 & 1.08 & 0.69 & 1.26 & 1.19 & 1.66 & 1.41 & 1.48 \\
\hline Wood & -0.64 & 1.20 & 1.82 & 2.25 & 3.03 & 3.98 & 2.33 & 2.58 & 3.19 & 3.24 & 3.16 & 3.20 \\
\hline Paper & 2.26 & 2.56 & 2.83 & 4.39 & -1.38 & 4.49 & 3.08 & 4.56 & 4.17 & 4.11 & 3.65 & 4.06 \\
\hline Chemicals & -1.73 & -2.16 & -2.60 & -2.41 & -2.21 & -4.20 & -3.08 & 0.66 & 1.44 & 0.32 & -0.74 & 0.75 \\
\hline Rubber and plastics & -0.17 & -0.27 & 1.53 & 1.06 & 0.72 & 0.75 & 0.01 & 0.48 & 1.17 & 0.80 & 0.41 & 0.38 \\
\hline Non-metallic products & 1.33 & 0.66 & 0.79 & 0.62 & 0.06 & 1.14 & 1.15 & 2.01 & 1.97 & 3.05 & 2.94 & 2.77 \\
\hline Basic metals & -2.21 & -1.49 & -0.66 & -1.40 & -0.36 & 0.54 & -1.07 & -0.22 & 1.03 & 0.24 & -0.34 & -1.05 \\
\hline Machinery and mech. app. & -2.73 & -0.32 & 0.92 & -0.70 & 2.06 & -3.18 & -3.33 & -4.81 & -1.60 & -2.09 & -3.13 & -0.66 \\
\hline Electrical machinery & -0.25 & -0.26 & 2.03 & 1.39 & 0.10 & 2.26 & 1.33 & 1.50 & 1.48 & 1.37 & 1.46 & 0.97 \\
\hline Medical and optical inst. & -0.56 & 0.16 & -0.28 & 0.28 & 1.41 & 0.65 & -0.56 & 0.11 & 1.16 & 0.51 & -1.31 & 0.20 \\
\hline Motor vehicles & -2.00 & -0.53 & 1.79 & -0.07 & 3.61 & 0.45 & -0.77 & n.a. & -1.17 & -2.40 & n.a. & -2.09 \\
\hline Furniture & -0.91 & -0.01 & 0.62 & 0.98 & -2.71 & 0.31 & -1.18 & -0.99 & -0.97 & 0.20 & 1.15 & 0.95 \\
\hline Other manufactured art. & 2.16 & 2.54 & 3.39 & 3.51 & 3.85 & 2.60 & 1.51 & 0.80 & 0.97 & 1.11 & 1.44 & 1.52 \\
\hline Other products, nec & -4.49 & -3.14 & -1.98 & -1.67 & 2.41 & -1.83 & -2.13 & -1.26 & -2.15 & -2.27 & -1.87 & -1.39 \\
\hline \multicolumn{13}{|l|}{ Bosnia and Herze govina } \\
\hline Food products & n.a. & n.a. & n.a. & n.a. & n.a. & n.a. & 0.91 & 0.74 & 0.95 & 1.28 & 1.12 & 0.85 \\
\hline Textile & n.a. & n.a. & n.a. & n.a. & n.a. & n.a. & 1.21 & 1.86 & 2.17 & 2.26 & 2.29 & 1.99 \\
\hline Apparel & n.a. & n.a. & n.a. & n.a. & n.a. & n.a. & 1.46 & 1.30 & 1.24 & 1.70 & 1.87 & 1.99 \\
\hline Leather and footwear & n.a. & n.a. & n.a. & n.a. & n.a. & n.a. & 0.49 & 0.33 & -0.05 & 0.00 & -0.21 & 0.11 \\
\hline Wood & n.a. & n.a. & n.a. & n.a. & n.a. & n.a. & -0.24 & -0.11 & 0.39 & 0.40 & 0.34 & 0.26 \\
\hline
\end{tabular}




\begin{tabular}{|c|c|c|c|c|c|c|c|c|c|c|c|c|}
\hline & 2002 & 2003 & 2004 & 2005 & 2006 & 2007 & 2008 & 2009 & 2010 & 2011 & 2012 & 2013 \\
\hline Paper & n.a. & n.a. & n.a. & n.a. & n.a. & n.a. & -1.77 & -2.22 & -2.74 & -2.08 & -2.09 & -1.77 \\
\hline Publishing and printing & n.a. & n.a. & n.a. & n.a. & n.a. & n.a. & 0.43 & 0.89 & -0.36 & -4.15 & -3.55 & -4.50 \\
\hline Chemicals & n.a. & n.a. & n.a. & n.a. & n.a. & n.a. & 2.16 & 2.19 & 2.17 & 1.64 & 1.95 & 2.55 \\
\hline Rubber and plastics & n.a. & n.a. & n.a. & n.a. & n.a. & n.a. & 0.02 & -0.54 & -0.26 & -0.33 & -0.46 & -0.63 \\
\hline Basic metals & n.a. & n.a. & n.a. & n.a. & n.a. & n.a. & 0.97 & 0.73 & 0.78 & 0.40 & 0.23 & 0.18 \\
\hline Fabricated metal products & n.a. & n.a. & n.a. & n.a. & n.a. & n.a. & 1.32 & 0.93 & 1.08 & 1.77 & 1.11 & 1.07 \\
\hline Machinery and mech. app. & n.a. & n.a. & n.a. & n.a. & n.a. & n.a. & 1.50 & 1.23 & 0.77 & 0.60 & 0.37 & 0.39 \\
\hline Electrical machinery & n.a. & n.a. & n.a. & n.a. & n.a. & n.a. & 1.38 & 1.00 & 0.96 & 0.63 & 0.62 & 0.06 \\
\hline Machinery and mech. app. & n.a. & n.a. & n.a. & n.a. & n.a. & n.a. & 2.05 & 2.17 & 1.95 & 1.83 & 1.94 & 1.47 \\
\hline Motor vehicles & n.a. & n.a. & n.a. & n.a. & n.a. & n.a. & 0.38 & 0.23 & 0.32 & 0.33 & -0.79 & -1.73 \\
\hline Furniture & n.a. & n.a. & n.a. & n.a. & n.a. & n.a. & 1.07 & 0.82 & 0.87 & 0.91 & 0.85 & 0.81 \\
\hline Toys and sports products & n.a. & n.a. & n.a. & n.a. & n.a. & n.a. & 0.80 & 0.51 & 0.45 & 1.33 & 0.10 & 0.33 \\
\hline Other manufactured art. & n.a. & n.a. & n.a. & n.a. & n.a. & n.a. & 1.09 & 0.66 & -0.23 & 0.24 & -1.33 & -1.36 \\
\hline Other products, nec & n.a. & n.a. & n.a. & n.a. & n.a. & n.a. & 0.62 & 0.11 & 0.43 & 0.32 & 0.46 & 0.88 \\
\hline \multicolumn{13}{|l|}{ Croatia } \\
\hline Food products & 0.21 & 0.01 & 0.11 & 0.75 & 0.73 & 0.65 & 0.63 & 0.62 & 0.62 & 0.47 & 0.38 & 0.77 \\
\hline Textile & 0.27 & -0.01 & -0.10 & 0.54 & 0.66 & 0.63 & 0.30 & 0.12 & 0.71 & 0.85 & 0.90 & 1.29 \\
\hline Apparel & 0.15 & -0.27 & -0.49 & -0.46 & -0.69 & -0.91 & -0.96 & -1.09 & -0.98 & -0.67 & -0.51 & -0.43 \\
\hline Leather and footwear & 0.06 & -0.31 & -0.47 & 0.05 & 0.37 & 0.14 & 0.17 & 0.04 & 0.47 & 0.85 & 0.67 & 0.03 \\
\hline Wood & 0.02 & -0.07 & -0.11 & 0.01 & -0.65 & -1.48 & -2.35 & -2.47 & -1.17 & -0.14 & -0.53 & -0.80 \\
\hline Paper & 0.03 & -0.01 & -0.06 & 0.74 & 0.57 & 0.04 & 0.34 & 0.53 & 0.73 & 1.51 & 1.15 & 1.36 \\
\hline Publishing and printing & 0.04 & 0.13 & 0.00 & -0.21 & -2.11 & -1.51 & -2.62 & -2.75 & -1.87 & -1.29 & -1.11 & -1.01 \\
\hline Chemicals & 0.14 & 0.10 & 0.07 & 0.46 & 0.47 & 0.63 & 0.16 & -0.42 & 0.01 & 0.46 & 0.35 & 0.32 \\
\hline Rubber and plastics & 0.06 & 0.07 & 0.04 & 1.32 & 1.02 & 0.30 & 0.12 & 0.07 & 0.47 & 0.27 & -0.45 & -0.63 \\
\hline Non-metallic products & 0.13 & 0.11 & 0.11 & 0.39 & 0.51 & 0.48 & 0.25 & 0.17 & 0.25 & 0.00 & -0.55 & -0.59 \\
\hline
\end{tabular}




\begin{tabular}{|c|c|c|c|c|c|c|c|c|c|c|c|c|}
\hline & 2002 & 2003 & 2004 & 2005 & 2006 & 2007 & 2008 & 2009 & 2010 & 2011 & 2012 & 2013 \\
\hline Basic metals & "-0.31 & 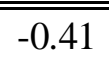 & 0.14 & 0.18 & -0.02 & 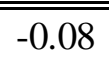 & -0.57 & 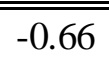 & -0.90 & -0.96 & -1.35 & - -1.37 \\
\hline Fabricated metal products & -0.90 & -1.02 & -1.14 & -0.86 & 0.48 & -0.75 & -1.26 & -1.29 & -1.59 & -1.10 & -1.95 & -1.87 \\
\hline Electrical machinery & 0.14 & 0.10 & 0.04 & 0.27 & 0.29 & 0.12 & -0.09 & -0.17 & -0.22 & -0.30 & -0.73 & -1.07 \\
\hline Medical and optical inst. & -0.02 & 0.01 & 0.02 & 0.21 & 0.10 & -0.10 & -0.13 & -0.15 & -0.11 & 0.01 & -0.27 & -0.41 \\
\hline Motor vehicles & 0.48 & 0.33 & 0.23 & 0.59 & 0.26 & -0.20 & -0.44 & -0.16 & -0.47 & -0.50 & -0.88 & -2.07 \\
\hline Furniture & 0.10 & 0.04 & 0.02 & 0.10 & 0.30 & 0.29 & -0.20 & -0.26 & -0.29 & -0.33 & -0.28 & -0.80 \\
\hline Toys and sports products & -0.24 & -0.52 & -0.90 & -0.56 & -5.08 & -6.28 & n.a. & -5.06 & -4.43 & -1.63 & -1.04 & -0.64 \\
\hline Other manufactured art. & -0.09 & -0.11 & -0.24 & 0.25 & 0.10 & 0.56 & 0.50 & 0.48 & 0.62 & 0.56 & 1.15 & 1.53 \\
\hline Other products, nec & 0.21 & 0.19 & 0.14 & 0.45 & 0.10 & 0.48 & 0.39 & 0.55 & 0.75 & 0.70 & 0.68 & 0.63 \\
\hline \multicolumn{13}{|l|}{ Macedonia } \\
\hline Food products & -1.31 & -0.70 & -1.68 & -0.85 & -2.45 & -3.38 & -3.25 & -3.17 & -4.16 & -3.88 & -3.48 & -2.81 \\
\hline Textile & -0.88 & 0.03 & 0.35 & 0.26 & 0.21 & 0.23 & -0.14 & -0.22 & -0.80 & -1.28 & -1.67 & -1.50 \\
\hline Apparel & -0.39 & 0.14 & 0.52 & 1.01 & 1.02 & 1.22 & 1.33 & 1.12 & 0.57 & 0.96 & 1.10 & 1.03 \\
\hline Leather and footwear & -0.77 & -0.60 & -0.05 & -0.14 & 0.24 & 0.08 & 0.07 & 0.05 & 0.04 & 0.07 & 0.07 & 0.18 \\
\hline Wood & -0.31 & 0.58 & -0.59 & -0.28 & 0.21 & 0.69 & 0.42 & 0.52 & 0.26 & 0.08 & -0.91 & -2.39 \\
\hline Paper & -3.07 & -2.81 & -1.47 & 0.12 & 0.00 & -0.76 & -0.53 & -0.78 & -1.72 & -1.28 & -2.16 & -2.63 \\
\hline Publishing and printing & -0.71 & -1.97 & n.a. & 3.47 & -0.29 & -3.14 & -3.83 & -4.33 & -4.51 & -3.36 & -4.25 & -4.99 \\
\hline Chemicals & -8.07 & -3.97 & -6.19 & -3.90 & -5.67 & -7.23 & -7.73 & -7.51 & -3.90 & -4.59 & -4.82 & -3.88 \\
\hline Rubber and plastics & -2.47 & -3.51 & -3.46 & -2.84 & -2.98 & -4.02 & -4.84 & -5.05 & -5.68 & -5.44 & -5.69 & -5.93 \\
\hline Non-metallic products & -1.86 & -2.23 & -3.47 & -2.56 & -8.07 & -7.03 & -7.14 & -4.43 & -8.89 & -4.05 & -3.68 & -4.90 \\
\hline Basic metals & 0.55 & 0.50 & -0.11 & -0.30 & -0.97 & -1.08 & -0.65 & -0.09 & -0.32 & 0.67 & 0.67 & 0.72 \\
\hline Fabricated metal products & -3.25 & -1.41 & -2.29 & -1.16 & -2.96 & -3.55 & -2.97 & -3.15 & -4.12 & -3.10 & -4.01 & -3.23 \\
\hline Machinery and mech. app. & -0.78 & -2.99 & -1.18 & -0.31 & -1.24 & -2.06 & -2.99 & -5.98 & n.a. & -5.19 & -6.61 & -9.13 \\
\hline Electrical machinery & -2.09 & -1.47 & -1.19 & -1.53 & -2.42 & -2.04 & -1.01 & -0.81 & -3.28 & -2.04 & -2.44 & -3.47 \\
\hline Medical and optical inst. & 1.12 & -4.35 & -3.88 & -7.91 & n.a. & -4.14 & n.a. & -2.23 & -3.31 & -2.28 & -1.31 & -1.32 \\
\hline
\end{tabular}




\begin{tabular}{|c|c|c|c|c|c|c|c|c|c|c|c|c|}
\hline & 2002 & 2003 & 2004 & 2005 & 2006 & 2007 & 2008 & 2009 & 2010 & 2011 & 2012 & 2013 \\
\hline Motor vehicles & -2.82 & -3.30 & -3.02 & -3.52 & -5.27 & -5.65 & -4.10 & -5.55 & -6.08 & -5.29 & -5.67 & -5.88 \\
\hline Furniture & -3.23 & -2.29 & -2.20 & -1.89 & -2.05 & -1.50 & -1.39 & -1.39 & -1.50 & -1.28 & -1.16 & -0.50 \\
\hline Other manufactured art. & 1.54 & -2.50 & 0.05 & 1.21 & 0.35 & 0.67 & 1.18 & 1.70 & 0.15 & 0.81 & -0.37 & -0.51 \\
\hline Other products, nec & -3.07 & -2.79 & -3.48 & -3.54 & -4.05 & -4.80 & -5.05 & -5.11 & -5.33 & -5.51 & -4.15 & -4.15 \\
\hline \multicolumn{13}{|l|}{ Serbia and Montenegro } \\
\hline Food products & n.a. & n.a. & n.a. & -2.35 & -1.07 & -0.79 & -1.47 & -1.48 & -1.39 & -0.82 & -1.02 & -0.80 \\
\hline Textile & n.a. & n.a. & n.a. & -1.33 & -1.26 & -0.92 & -0.46 & -0.59 & -1.50 & -1.31 & -1.17 & -0.93 \\
\hline Apparel & n.a. & n.a. & n.a. & -0.40 & -0.24 & -0.06 & -0.21 & -0.17 & -0.13 & -0.39 & -1.15 & -1.28 \\
\hline Leather and footwear & n.a. & n.a. & n.a. & -0.83 & -0.40 & -0.77 & -0.87 & -1.06 & -1.13 & -0.86 & -1.17 & -0.99 \\
\hline Wood & n.a. & n.a. & n.a. & -1.50 & 0.34 & 0.21 & 1.25 & 1.25 & 0.06 & -0.33 & -0.88 & -0.73 \\
\hline Paper & n.a. & n.a. & n.a. & -3.78 & -0.70 & -0.22 & -0.01 & -0.16 & -0.12 & -2.26 & -1.55 & -1.39 \\
\hline Publishing and printing & n.a. & n.a. & n.a. & -0.04 & -2.21 & 0.64 & 0.65 & 0.67 & 0.77 & 0.60 & 0.65 & 0.64 \\
\hline Chemicals & n.a. & n.a. & n.a. & -2.05 & -1.18 & -1.66 & -1.21 & -0.54 & -0.49 & -0.72 & -0.66 & -0.74 \\
\hline Rubber and plastics & n.a. & n.a. & n.a. & -2.32 & -0.80 & -0.15 & -0.01 & 0.14 & -0.21 & 0.02 & 0.28 & 0.25 \\
\hline Non-metallic products & n.a. & n.a. & n.a. & -1.96 & -1.46 & -1.67 & -0.46 & -0.11 & -0.66 & 0.36 & 0.60 & 0.43 \\
\hline Basic metals & n.a. & n.a. & n.a. & 0.08 & 0.23 & 0.29 & -0.04 & -0.07 & -0.19 & -0.21 & 0.03 & -0.20 \\
\hline Fabricated metal products & n.a. & n.a. & n.a. & -2.31 & -1.07 & -1.58 & -1.14 & -1.22 & -1.26 & -0.54 & -1.22 & -1.48 \\
\hline Machinery and mech. app. & n.a. & n.a. & n.a. & -0.88 & -0.51 & -0.05 & -0.36 & -0.38 & 0.02 & 0.09 & 0.26 & 0.29 \\
\hline Electrical machinery & n.a. & n.a. & n.a. & -1.64 & -0.70 & -0.24 & 0.01 & 0.21 & 0.38 & 0.58 & 0.87 & 0.90 \\
\hline Medical and optical inst. & n.a. & n.a. & n.a. & -1.42 & -0.46 & 0.31 & -0.18 & -0.28 & -0.08 & -0.29 & -0.02 & 0.07 \\
\hline Motor vehicles & n.a. & n.a. & n.a. & -1.33 & -0.51 & 0.56 & 0.61 & 0.29 & 0.50 & 0.47 & 0.99 & 1.01 \\
\hline Furniture & n.a. & n.a. & n.a. & -0.30 & -0.70 & -0.72 & -1.41 & -1.09 & -1.28 & -1.48 & -1.58 & -1.20 \\
\hline Toys and sports products & n.a. & n.a. & n.a. & -3.04 & -1.07 & 0.11 & -0.54 & -1.23 & -0.16 & 0.52 & -1.16 & -1.97 \\
\hline Other manufactured art. & n.a. & n.a. & n.a. & -2.17 & -2.03 & -1.90 & -1.42 & -0.88 & -1.04 & -1.01 & -1.76 & -1.48 \\
\hline Other products, nec & n.a. & n.a. & n.a. & -2.20 & -1.27 & -1.06 & -1.12 & -0.79 & -1.54 & -1.57 & -1.01 & -0.57 \\
\hline
\end{tabular}




\subsection{What is the impact of international fragmentation on Western Balkan countries growth performance?}

In this section, we rely on panel data estimation methodology to test the effects of international fragmentation of production on WBC economic activity. In particular, following the recent literature ${ }^{41}$, we assume that the relative intensity of processing trade constitutes a separate item in the overall aggregate demand in a given country and thus its changes will affect the level of economic activity and GDP growth. Based on this idea, we seek to verify whether or not the divergences in the degree of participation of the WBC in the IPN help us to explain the observed differences in their GDP growth rates and to determine the distinctive influence of this participation on their economic behavior.

Accordingly, we initially estimate through several regression models the differential GDP growth rate of the considered WBC with respect to the region's average. We next estimate the GDP growth rate of each Western Balkan country separately. These two endogenous variables are explained by the propensity index of international fragmentation (in logs), defined in the previous section, as our main regressor ${ }^{42}$. Additionally, to control for other factors that might influence the aggregate demand and thereby the GDP growth rates, we consider elements of both domestic and foreign demand. In particular, we include the level of final consumption and gross capital formation to capture changes in domestic demand, on the one hand, and exports to account for variations in foreign demand, on the other. We have also added FDI inflows to evaluate the positive influence that the establishment of multinational firms may exert on the recipient country's economic performance, as has been broadly highlighted in the literature (see, for instance, Alguacil et al. 2011).

More specifically, the estimating equation takes the following form:

$$
\begin{aligned}
\text { gdpgd }_{i t}=\beta_{0} & +\beta_{1} \text { liif }_{i t}+\beta_{2} \text { exp }_{i t}+\beta_{3} \text { fincons }_{i t}+\beta_{4} \text { capform }_{i t}+\beta_{5} \text { fdi }_{i t}+\lambda_{t} \\
& +\mu_{i}+\varepsilon_{i t}
\end{aligned}
$$

\footnotetext{
${ }^{41}$ See for example Samuelson (2001), Helg and Tajoli (2005) or Ramondo and Rodríguez-Clare (2009).

42 Given data limitations, we include in the regression the country-specific version of the index. No sectoral data for the rest of variables are available for Albania, Bosnia and Herzegovina and Montenegro.
} 
where $i$ stands for each Western Balkan country and $t$ denotes time. The level of capital formation, capform, total and final exports, exp, and the net inflows of foreign direct investment, $f d i$, are all expressed as a percentage of GDP. The variable fincons represents the difference between final consumption growth rate of country $i$ and the weighted average of the growth rate of final consumption in the WBC. The error terms $\lambda_{t}$ and $\mu_{i j}$ comprise time effects and unobserved bilateral effects, respectively. The remaining error $\varepsilon_{i t}$ is assumed to be independent across countries and over time. The analyzed period is from 2002 to 2013. The definitions and sources of all variables are detailed in Table 5 below.

Table 5. Definitions and data sources

\begin{tabular}{|c|c|c|}
\hline Abbreviation & Definition & Data source \\
\hline gdprealdiff & $\begin{array}{l}\text { The differential between the GDP growth rate } \\
\text { of the considered WBC with respect to the } \\
\text { region's average }\end{array}$ & $\begin{array}{l}\text { World Development } \\
\text { Indicators and } \\
\text { authors calculations }\end{array}$ \\
\hline gdpreal & $\begin{array}{l}\text { Annual percentage growth rate of GDP at } \\
\text { market prices based on constant local currency }\end{array}$ & $\begin{array}{l}\text { World Development } \\
\text { Indicators }\end{array}$ \\
\hline liif & $\begin{array}{l}\text { Log of the Index of International } \\
\text { Fragmentation }\end{array}$ & $\begin{array}{l}\text { Eurostat and authors } \\
\text { calculations }\end{array}$ \\
\hline totalexp & Total exports as percent of GDP & UN Comtrade \\
\hline finexp & $\begin{array}{l}\text { Final exports as percent of GDP. Final exports } \\
\text { are defined as goods exported definitely }\end{array}$ & $\begin{array}{l}\text { World Development } \\
\text { Indicators }\end{array}$ \\
\hline fincons & $\begin{array}{l}\text { Difference between final consumption growth } \\
\text { rate of country } i \text { and the weighted average of } \\
\text { the growth rate of final consumption in the } \\
\text { Western Balkan countries }\end{array}$ & $\begin{array}{l}\text { World Development } \\
\text { Indicators and } \\
\text { authors calculations }\end{array}$ \\
\hline capform & $\begin{array}{l}\text { Gross capital formation (or gross investment) } \\
\text { as percent of GDP }\end{array}$ & $\begin{array}{l}\text { World Development } \\
\text { Indicators }\end{array}$ \\
\hline fdi & Foreign direct investment as percent of GDP & $\begin{array}{l}\text { World Development } \\
\text { Indicators }\end{array}$ \\
\hline
\end{tabular}

As previously mentioned, the above equation is estimated using a panel data approach. This methodology allows us to account for unobserved individual heterogeneity. The effects of this heterogeneity can be constant and correlated with independent variables (fixed-effects model) or random and uncorrelated with independent variables (randomeffects model $)^{43}$. Moreover, it is a well-known fact that panel data provide more degrees of freedom, less collinearity and therefore more efficiency. For the sake of robustness, we employ different specifications and estimation methods.

\footnotetext{
${ }^{43}$ See Baltagi (2013) for a more detailed information about panel data models.
} 
Table 6. Estimation results using random effects: 2002-2013.

\begin{tabular}{|c|c|c|c|c|c|c|}
\hline Dependent variable & GDP real & th differenc & & GDP real & & \\
\hline Explanatory variables & Model 1 & Model 2 & Model 3 & Model 4 & Model 5 & Model 6 \\
\hline 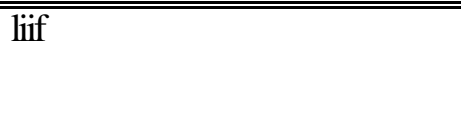 & $\begin{array}{l}1.136 * * * \\
(0.450)\end{array}$ & $\begin{array}{l}1.399 * * * \\
(0.561)\end{array}$ & $\begin{array}{l}1.710 * * * \\
(0.403)\end{array}$ & $\begin{array}{l}1.123 * * \\
(0.470)\end{array}$ & $\begin{array}{l}1.373 * * \\
(0.564)\end{array}$ & $\begin{array}{l}1.680 * * * \\
(0.405)\end{array}$ \\
\hline totalexp & & $\begin{array}{l}0.060 * \\
(0.032)\end{array}$ & & & $\begin{array}{l}0.059 * \\
(0.032)\end{array}$ & \\
\hline finexp & & & $\begin{array}{l}0.106 * * * \\
(0.027)\end{array}$ & & & $\begin{array}{l}0.103^{* * * *} \\
(0.027)\end{array}$ \\
\hline fincons & & $\begin{array}{l}0.084 \\
(0.068)\end{array}$ & $\begin{array}{l}0.069 \\
(0.059)\end{array}$ & & $\begin{array}{l}0.083 \\
(0.069)\end{array}$ & $\begin{array}{l}0.068 \\
(0.060)\end{array}$ \\
\hline capform & & $\begin{array}{l}0.163 * * * \\
(0.059)\end{array}$ & $\begin{array}{l}0.139 * * * \\
(0.052)\end{array}$ & & $\begin{array}{l}0.164 * * * \\
(0.059)\end{array}$ & $\begin{array}{l}0.140 * * * \\
(0.052)\end{array}$ \\
\hline fdi & & $\begin{array}{l}0.279 * * * \\
(0.084)\end{array}$ & $\begin{array}{l}0.272 * * * \\
(0.061)\end{array}$ & & $\begin{array}{l}0.277 * * * \\
(0.085)\end{array}$ & $\begin{array}{l}0.270 * * * \\
(0.061)\end{array}$ \\
\hline const & $\begin{array}{l}-1.314 \\
(1.032)\end{array}$ & $\begin{array}{l}-7.487 * * * \\
(1.929)\end{array}$ & $\begin{array}{l}-6.459 * * * \\
(1.771)\end{array}$ & $\begin{array}{l}3.055^{* * * *} \\
(1.177)\end{array}$ & $\begin{array}{l}-3.093 \\
(1.946)\end{array}$ & $\begin{array}{l}-2.088 \\
(1.797)\end{array}$ \\
\hline Number of observations & 50 & 49 & 49 & 50 & 49 & 49 \\
\hline Adjusted $\mathrm{R}^{2}$ & 0.314 & 0.602 & 0.611 & 0.751 & 0.853 & 0.856 \\
\hline Hausman test & 0.999 & 0.837 & 0.939 & 0.999 & 0.841 & 0.939 \\
\hline $\begin{array}{l}\text { Over-identifying restrictions } \\
\text { test: fixed vs random effects }\end{array}$ & 0.111 & 0.203 & 0.162 & 0.784 & 0.937 & 0.896 \\
\hline
\end{tabular}


Table 7. Estimation results using TSLS and GMM Instrumental Variables: 2002-2013.

\begin{tabular}{|c|c|c|c|c|c|c|c|c|}
\hline \multirow{3}{*}{$\begin{array}{l}\text { Dependent variable } \\
\text { Explanatory variables }\end{array}$} & \multicolumn{4}{|c|}{ GDP real growth difference } & \multicolumn{4}{|c|}{ GDP real growth } \\
\hline & \multicolumn{2}{|l|}{ IV } & \multicolumn{2}{|l|}{ GMM } & \multicolumn{2}{|l|}{ IV } & \multicolumn{2}{|l|}{ GMM } \\
\hline & Model 1 & Model 2 & Model 3 & Model 4 & Model 5 & Model 6 & Model 7 & Model 8 \\
\hline liif & $\begin{array}{l}1.888 * * * \\
(0.456)\end{array}$ & $\begin{array}{l}2.228 * * * \\
(0.514)\end{array}$ & $\begin{array}{l}1.818 * * * \\
(0.482)\end{array}$ & $\begin{array}{l}2.072 * * * \\
(0.510)\end{array}$ & $\begin{array}{l}1.864 * * * \\
(0.458)\end{array}$ & $\begin{array}{l}2.202 * * * \\
(0.516)\end{array}$ & $\begin{array}{l}1.797 * * * \\
(0.484)\end{array}$ & $\begin{array}{l}2.052 * * * \\
(0.513)\end{array}$ \\
\hline totalexp & $\begin{array}{l}0.087 * * * \\
(0.026)\end{array}$ & & $\begin{array}{l}0.084 * * * \\
(0.023)\end{array}$ & & $\begin{array}{l}0.086 * * * \\
(0.027)\end{array}$ & & $\begin{array}{l}0.083^{* * * *} \\
(0.023)\end{array}$ & \\
\hline finexp & & $\begin{array}{l}0.138^{* * * *} \\
(0.041)\end{array}$ & & $\begin{array}{l}0.129 * * * \\
(0.037)\end{array}$ & & $\begin{array}{l}0.136^{* * * *} \\
(0.041)\end{array}$ & & $\begin{array}{l}0.128 * * * \\
(0.038)\end{array}$ \\
\hline fincons & $\begin{array}{l}0.090 * \\
(0.049)\end{array}$ & $\begin{array}{l}0.074 \\
(0.049)\end{array}$ & $\begin{array}{l}0.089 * * \\
(0.041)\end{array}$ & $\begin{array}{l}0.076 * \\
(0.044)\end{array}$ & $\begin{array}{l}0.090 * \\
(0.049)\end{array}$ & $\begin{array}{l}0.074 \\
(0.049)\end{array}$ & $\begin{array}{l}0.089 * * \\
(0.041)\end{array}$ & $\begin{array}{l}0.076^{*} \\
(0.044)\end{array}$ \\
\hline capform & $\begin{array}{l}0.098 \\
(0.066)\end{array}$ & $\begin{array}{l}0.069 \\
(0.068)\end{array}$ & $\begin{array}{l}0.102 * \\
(0.060)\end{array}$ & $\begin{array}{l}0.079 \\
(0.061)\end{array}$ & $\begin{array}{l}0.098 \\
(0.066)\end{array}$ & $\begin{array}{l}0.069 \\
(0.068)\end{array}$ & $\begin{array}{l}0.102 * \\
(0.060)\end{array}$ & $\begin{array}{l}0.078 \\
(0.061)\end{array}$ \\
\hline fdi & $\begin{array}{l}0.446^{* * * *} \\
(0.109)\end{array}$ & $\begin{array}{l}0.434 * * * \\
(0.103)\end{array}$ & $\begin{array}{l}0.418 * * * \\
(0.132)\end{array}$ & $\begin{array}{l}0.381 * * * \\
(0.121)\end{array}$ & $\begin{array}{l}0.445^{* * *} \\
(0.110)\end{array}$ & $\begin{array}{l}0.433 * * * \\
(0.104)\end{array}$ & $\begin{array}{l}0.419 * * * \\
(0.134)\end{array}$ & $\begin{array}{l}0.383^{* * * *} \\
(0.123)\end{array}$ \\
\hline const & $\begin{array}{l}-6.187 * * * \\
(1.590)\end{array}$ & $\begin{array}{l}-5.169 * * * \\
(1.481)\end{array}$ & $\begin{array}{l}-6.137 * * * \\
(1.359)\end{array}$ & $\begin{array}{l}-5.107 * * * \\
(1.379)\end{array}$ & $\begin{array}{l}-5.323 * * * \\
(1.597)\end{array}$ & $\begin{array}{l}-4.325 * * * \\
(1.487)\end{array}$ & $\begin{array}{l}-5.271 * * * \\
(1.374)\end{array}$ & $\begin{array}{l}-4.259 * * * \\
(1.399)\end{array}$ \\
\hline Number of observations & 46 & 46 & 46 & 46 & 46 & 46 & 46 & 46 \\
\hline Adjusted $\mathrm{R}^{2}$ & 0.563 & 0.566 & 0.574 & 0.580 & 0.851 & 0.852 & 0.854 & 0.857 \\
\hline $\begin{array}{l}\text { Over-identifying } \\
\text { restrictions test }\end{array}$ & 0.52 & 0.32 & 0.48 & 0.24 & 0.54 & 0.34 & 0.51 & 0.26 \\
\hline Endogeneity test & 0.08 & 0.05 & 0.04 & 0.03 & 0.08 & 0.05 & 0.04 & 0.02 \\
\hline
\end{tabular}


As a first assessment of the impact of the propensity to participate in IPN on growth, we run initially a baseline model, with the index of international fragmentation as the sole regressor. Next, and in line with previous empirical works, an extended model is estimated by considering the effects of domestic and foreign factors of demand on economic growth. In Table 6, we present the results obtained from the estimation of these models using the random-effects methodology. The decision regarding whether to consider unobserved country-specific effects as random was made on the basis of the Hausman test ${ }^{44}$.

For the sake of comparison and to deal with the problem of reverse causality or simultaneity, we also show in Table 7 the coefficients of the extended model using two-stage least squares (TSLS) and Generalized Method of Moments (GMM) Instrumental Variable (IV) techniques. The plausibility of both the potential positive impact of an increase in trade and FDI on GDP growth and the possibility of these external factors being enhanced by a higher rate of economic growth are well documented in the literature. According to Irwin and Terviö (2002), the efforts to estimate the effects of international trade on a country's real income have been hampered by the failure to account for the endogeneity of trade ${ }^{45}$. Similarly, for Borensztein et al. (1998), the correlation between FDI and growth rate could arise from an endogenous determination of FDI, as foreign investments itself may be influenced by innovations in the stochastic process governing growth rates. Ignoring these effects might lead to the impact of these variables being overstated and to significant relationships being found where they do not in fact exist.

The problem of regressors correlated with the error term due to the simultaneous nature of the model results in inconsistent OLS estimates. Therefore, with endogenous explanatory variables, we must resort to TSLS and GMM methods (see Biørn and Krishnakumar, 2008). However, one of the major problems with the TSLS estimation method is the difficulty in identifying instruments that are highly correlated with the explanatory variables but not with the error terms $^{46}$. This problem is solved in the standard GMM estimator (Arellano and Bond, 1991) as the

\footnotetext{
${ }^{44}$ The results of this test are presented at the bottom of Table 6 . As can be seen, the random-effects estimation is preferred to the fixed-effect estimation in all cases.

45 Their work is based on Frankel and Romer (1999). These authors employed country's geographical attributes to control for endogeneity of trade in the identification of the effects of this variable on income.

${ }^{46}$ Following the existing literature (see, e.g., Alfaro and Charlton 2007; Borensztein et al. 1998; Makki and Somwaru 2004), we use the lagged values of FDI and the log of the real effective exchange rate as instruments for FDI.
} 
lagged levels of all the right hand side variables are used as instruments, which eliminates the arbitrariness in the selection of instruments ${ }^{47}$.

As can be seen from the above tables, our outcomes support the hypothesis that greater participation in the international fragmentation of production exerts a beneficial influence on the economic behavior of the WBC. This is a very robust result as the variable liif is positive and highly significant in all regressions for both the economic growth differences and the country's GDP growth rate ${ }^{48}$. Our findings also sustain the hypothesis that the degree of involvement in international production networks positively influences the economic performance of the WBC, even once the gains of total or final goods trade are considered. Thus, a higher degree of participation in IPN of the WBC gives them the possibility of achieving higher productivity and is a powerful contributor to growth, complementing the impacts generated by the total and final goods trade. Similar results are obtained by Baldone et al. (2007) for the EU countries and by Foster et al. (2013) for forty advanced and emerging economies. Therefore, the estimates corroborate the idea that the growth-enhancing impact of this phenomenon exceeds the underlying growth effect of an increase in total trade.

Our results also show the importance of taking into account the role played by multinational firms in the WBC. Regardless of the domestic and foreign demand, foreign direct investments appear to be an important factor in the explanation of their differences in terms of economic growth. As can be seen in Tables 6 and 7, fdi has a positive and a very significant coefficient in all models considered. On the contrary, the coefficient of the domestic demand variables, despite having the expected sign, are not always statistically significant. According to the results of the estimation of random effects, capform has a significant and positive effect on the economic growth of these countries. However, in the regressions by instrumental variables the significance of this variable disappears once the endogenous nature of the explanatory variables is considered. Conversely, domestic consumption is insignificant in the random effects estimation, but is significant in most specifications of the IV estimation. The endogeneity and over-identification

\footnotetext{
47 Indeed the terms IV and GMM can be used indistinctly, as all IV estimators can also be interpreted as GMM estimators using the corresponding moment conditions.

48 The correlation matrix already revealed a positive correlation coefficient between the index of international fragmentation and GDP growth (on request).
} 
tests reported at the bottom of Table 7 confirm both the endogenous character of some of our regressors and the correct specification of the different models.

\subsection{Conclusions}

As part of their recent modernization and economic development, the WBC have played an active role in international production networks. Data clearly show that the WBC are a far more important destination of processing trade than a source of it. In fact, inward processing trade reaches as much as forty percent of the corresponding amount of final trade exports, with the EU being the main partner for it. Therefore, it is of particular interest to analyze the impact of a higher degree of participation in international fragmentation of production on the economic performance of these countries.

To capture the relative tendency of each country to participate in international production networks, we have elaborated a Balassa-type index of international fragmentation that considers both types of trade: processed and final. A descriptive analysis of this index has revealed two relevant facts. First, it confirms the increasing role played by inward processing trade in the WBC during the analyzed period, although with a different magnitude depending on countries and sectors. Second, a more disaggregated analysis of this index reveals that the WBC have undergone a positive structural shift in industrial distribution towards higher value-added industries.

The econometric analysis undertaken confirms the positive influence of the increased processing trade in these countries. Through the estimation of a set of panel data models, our results reveal that the relative tendency of each country to participate in this globalization process significantly affects its economic performance, measured in terms of both differential and absolute GDP growth. Moreover, the effects of processing trade appear to be present together with the positive influence of traditional trade. The beneficial impact that the establishment of multinational firms has on economic growth is also verified by the sign and magnitude of our estimates. This outcome shows how relevant multinational firms' global strategies are for the trade pattern and economic activity of these countries. 
Overall, our findings support the idea that policies designed to promote the openness and participation of the $\mathrm{WBC}$ in the international division of production could be considered an important stimulus for the development and growth of these countries. The promotion of a certain type of economic policies may induce these countries to better exploit their comparative advantages improving so their likelihood of a successful economic modernization. Further research should focus on a more disaggregated approach, considering the increased relevance of sectors with higher valued added. 


\section{References}

Alfaro, L., and A. Charlton. 2007. "Intra-Industry Foreign Direct Investment." American Economic Review, 99(5):2096-2119.

Alguacil, M., Cuadros, A., and V. Orts. 2011. "Inward FDI and growth: The role of macroeconomic and institutional environment." Journal of Policy Modeling 33, no. 3: 481496.

Amiti, M., and S-J. Wei. 2009. "Service offshoring and productivity: Evidence from the US." The World Economy 32, no. 2: 203-220.

Arellano, M. and Bond, S. 1991. "Some Tests of Specification for Panel Data: Monte Carlo Evidence and an Application to Employment Equations." Review of Economic Studies 58:277-297.

Arndt, S.W. 1997. "Globalization and the open economy." North American Journal of Economics and Finance 8, no. 1:71-79.

Arndt, S.W. and Kierzkowski, H., 2001. "Fragmentation: new production and trade patterns in the world economy." Oxford: Oxford University Press.

Athukorala, P., and N. Yamashita. 2006. "Product fragmentation and trade integration: East Asia in global context." North American Journal of Economics and Finance 17(3): 233-256.

Baldone, S., Sdogati, F., and L. Tajoli. 2007. "On Some Effects of International Fragmentation of Production on Comparative Advantages, Trade Flows and the Income of Countries." The World Economy 30, no. 11: 1726- 1769.

Baldwin, R. 2014. Trade and industrialization after globalization's second unbundling: how building and joining a supply chain are different and why it matters, In R.C. Feenstra and A.M. Taylor (eds.), Globalization in an Age of Crisis: Multilateral Economic Cooperation in the Twenty-First Century (chapter 5, pp. 165-212). Chicago, IL: University of Chicago Press.

Baltagi, B. 2013. Econometric analysis of panel data. 5th Edition. John Wiley \& Sons. 
Barrientos, S., Gereffi, G. and Rossi, A., "Economic and social upgrading in global production networks: A new paradigm for a changing world." International Labour Review, 150 (3-4), 319-340

Biørn, E. and J. Krishnakumar. 2008. Measurement errors and simultaneity. Ch. 9, in Mátyás, L., and Sevestre, P. (Eds.). The econometrics of panel data: fundamentals and recent developments in theory and practice (Vol. 46). Springer, Heidelberg.

Borensztein, E., De Gregorio, J., and J-W. Lee. 1998. "How does foreign direct investment affect economic growth?” Journal of International Economics 45, no. 1: 115-135.

Deardorff, A.V. 1998. "Fragmentation across cones." Research Seminar in International Economics, Working papers no. 427, University of Michigan, Ann Arbor.

Deardorff, A.V. 2001. "Fragmentation in simple trade models." North American Journal of Economics and Finance 12, no. 2: 121-137.

Dixit, A.K., and J.E. Stiglitz 1977. "Monopolistic competition and optimum product diversity." American Economic Review 67, no. 3: 297-308.

Egger, P., Pfaffermayr, M.; and Y. Wolfmayer-Schnidzer. 2001. "The international fragmentation of Austrian manufacturing: The effects of outsourcing on productivity and wages." The North American Journal of Economics and Finance 12, no. 3: 257-272.

Eurostat 2014. Monthly DVD publications on Traditional international trade database access (Comext) at http//ec.europa.eu/eurostat/web/international-trade/publications/comext-dvs.

Feenstra, R.C. 1998. "Integration of trade and disintegration of production in the global economy." Journal of Economic Perspectives 12: 31-50.

Feenstra, R.C.; and G.H., Hanson. 1997. "Foreign direct investment and relative wages: evidence from Mexico's Maquiladoras." Journal of International Economics 42, 371-393. 
Foster, N., Stehrer, R.; and M. Timmer. 2013. 'International Fragmentation of Production, Trade and Growth: Impacts and Prospects for EU Member States.” wiiw Working Paper, no. 387, Vienna.

Frankel, J., and D. Romer. 1999. Does trade cause growth? American Economic Review 89, 379-399.

Gereffi, G. 1999. "International trade and industrial upgrading in the apparel commodity chain." Journal of International Economics 48: 37-70.

Gereffi, G., Humphrey, J. and Sturgeon, T. 2005. "The governance of global value chains." Review of International Political Economy 12:1 February 2005: 78-104

Goldberg, P. K., A. K. Khandelwal, N. Pavcnik and P. Topalova (2010). "Imported Intermediate Inputs and Domestic Product Growth: Evidence from India," The Quarterly Journal of Economics, MIT Press, 125(4),1727-1767.

Görg, H., 2000. "Fragmentation and trade: US inward processing trade in the EU." Review of World Economics (Weltwirtschaftliches Archiv) 136: 403-422.

Grubel, H., and P.J. Lloyd. 1975. Intra-industry trade: theory and measurement of international trade in differentiated products. New York: John Wiley.

Helg, R. and L. Tajoli. 2005. "Patterns of international fragmentation of production and the relative demand for labor." The North American Journal of Economics and Finance 16, no. 2: $233-254$

Helpman, E. and P. Krugman. 1985. Market structure and foreign trade: increasing returns, imperfect competition, and the international economy. Cambridge, MA: MIT Press.

Hummels, D., Ishii, J.; and K-M. Yi. 2001. "The nature and growth of vertical specialization in world trade." Journal of International Economics 54, no. 1: 75-96.

IMF 2015. The western Balkans : 15 years of economic transition. - Washington, D.C. : International Monetary Fund, 2015. 
Irwin, D.A. and M. Terviö. 2002. "Does trade raise income? Evidence from the twentieth century, Journal of International Economics 58, 1-18.

Jones, R.W., and H. Kierzkowski. 1990. "The role of services and production in international trade: a theoretical framework." In: R.W. Jones and A.O. Krueger, eds. The political economy of international trade: essays in honour of Robert E. Baldwin. Malden, MA: Basil Blackwell: $31-48$.

Jones, R.W. and H. Kierzkowski. 2001. "A framework for fragmentation." In: S.W. Arndt and H. Kierzkowski, eds. Fragmentation: new production patterns in the world economy. Oxford: Oxford University Press: 17-34.

Jones, C. 2011. "Intermediate Goods and Weak Links in the Theory of Economic Development." American Economic Journal: Macroeconomics 3: 1- 28.

Krugman, P. 1980. "Scale economies, product differentiation and the pattern of trade." American Economic Review 70: 950-959.

Krugman, P. 1995. "Growing world trade: causes and consequences." Brookings papers on economic activity 1: 327-377.

Locke, R., Kochan, T., Romis, M., and Qin, F. 2007. "Beyond corporate codes of conduct: Work organization and labour standards at Nike's suppliers", in International Labour Review, Vol. 146, No. 1-2, pp. 21-40.

Los, B., Timmer, M.P. and de Vries, G.J. 2015. "How global are global value chains? A new approach to measure international fragmentation." Journal of Regional Science. vol. 55, No. 1, 2015, pp. 66-92

Makki, S.S., and A. Somwaru. 2004. "Impact of Foreign Direct Investment and Trade on Economic Growth: Evidence from Developing Countries." American Journal of Agricultural Economics 86, no. 3: 795-801.

Miroudot, S., Lanz, R., and A. Ragoussis. 2009. "Trade in Intermediate Goods and Services." OECD Trade Policy Papers, no. 93, OECD Publishing. 
Mudambi, R. and M. Venzin. 2010. "The strategic nexus of offshoring and outsourcing decisions." Journal of Management Studies 47, no. 8: 1510-33.

OECD 2013. Interconnected Economies: Benefiting From Global Value Chains, Paris: Organization for Economic Co-operation and Development.

Ramondo, N. and A. Rodríguez-Clare. 2009. "Trade, Multinational Production, and the Gains from Openness." NBER working paper, no. 15604.

Rossi, A. 2011. "Economic and social upgrading in global production networks: The case of the garment industry in Morocco." DPhil dissertation. Brighton, Institute of Development Studies, University of Sussex.

Samuelson, P.A. 2001. "A Ricardo-Sraffa Paradigm Comparing Gains from Trade in Inputs and Finished Goods.” Journal of Economic Literature 39, no. 4: 1204-1214.

Shimbov. B., Alguacil. M., and C. Suárez. 2013. "Fragmentation and parts and components trade in the Western Balkan countries." Post-Communist Economies 25, no. 3: 371-391

Shiozawa, Y. 2007. "A new construction of Ricardian trade theory - A many-country, manycommodity case with intermediate goods and choice of production techniques." Evolutionary and Institutional Economics Review 3, no. 2: 141-187.

Stehrer, R. and J. Wörz. 2009. "Industrial Diversity, Trade Patterns, and Productivity Dynamics", Review of Development Economics 13, no. 2: 356-372.

UNCTAD. 2013. "Key Trends in International Merchandise Trade." United Nations Conference on Trade and Development, New York and Geneva: United Nations.

World Trade Organization 2011 The WTO and preferential trade agreements: From co-existence to coherence (World Trade Report 2011): WTO.

Yeats, A.J., 2001. "How big is global production sharing?" In: S.W. Arndt and H. Kierzkowski, eds. Fragmentation: new production patterns in the world economy. Oxford: Oxford University Press, 108-144. 


\title{
Chapter III
}

\section{Export sophistication and economic growth in the Western Balkans}

\begin{abstract}
Over the past two decades, the Western Balkan Countries have undergone deep institutional and economic reforms that have resulted in significant changes in their production processes and export structure. Most of these economies recently opened up to the global market and, as they become increasingly export-oriented, have enjoyed significant growth in recent years that has contributed to a convergence trend of incomes per capita with high-income countries. The recent literature has related this process to the structural transformation of production and exports (Lall et al., 2006; Hausman et al., 2007; Jarreau and Poncet, 2012). According to these studies, successful developing and transition economies have progressively changed their productive structure, replacing low-value-added activities and unsophisticated goods with higher-valueadded activities and more sophisticated products, thus increasing the competitiveness of their production and trade. In this chapter, we seek both to analyze the impact that this structural change has on the economic performance of the WBC and to determine the factors fostering this process. To do so, we elaborate an export sophistication index, à la Hausmann, focusing on the period 1996-2014. The results obtained, using a set of panel data models, show that export sophistication has a positive and significant effect on economic growth in the WBC. However, we find that it is not the sophistication in high-skill goods but rather the increased sophistication in medium-skill and technology-intensive manufactured goods that is driving this process. We also find that both economic and financial development and greater competition are critical factors in stimulating export sophistication in the WBC.
\end{abstract}

JEL classifications: F14; F63; O4

Key words: Export sophistication, Economic growth, International production networks, Western Balkan countries, Panel data models 


\subsection{Introduction}

The last two decades have been one of the most favorable periods in terms of economic performance for many East European nations. During the transition period they opened up their economies and followed an export-led growth model, resulting in an increase in their income level and higher growth rates (IMF 2014, 2015). Some recent studies have related this economic development to the structural transformation of the production process and changing export patterns experienced by these countries. According to Hausmann et al. (2007), for instance, the change from low-value-added production to high-value-added production has been crucial to the economic development of many economies. Thus, for these authors, what a country produces and exports matters in explaining growth. In this chapter, we aim to examine how the structural transformation of the production and the increasing sophistication of exports in the Western Balkan countries ${ }^{49}$ influence their economic performance and shed light on their growth patterns.

As is well known, some products may yield greater knowledge spillovers, have a greater potential for backward and forward linkages, or offer an easier pathway compared to other products with similar characteristics. Such products are more sophisticated in the sense that they are associated with higher productivity levels and knowledge. A country's production structure may become more sophisticated either through an increase in the quality of previously produced goods, or by creating new and more sophisticated ones. The ability of a country to increase internal value added and so to produce goods that are more sophisticated and competitive in international markets is associated with faster economic growth. According to a recent report (UNCTAD 2013), since 2006 the degree of export sophistication has risen more in high-income countries and middle-income developing countries than in low-income nations. Moreover, export sophistication in transition economies is in general higher than the expected level at their stage of development. The WBC had not been an exception to this process. Recent economic modernization and growing openness of the WBC facilitated the upgrading of their productive structure and their increasing export sophistication (UNCTAD 2015).

Given the increasing globalization and integration of the world's markets, parts of the production process, or even the entire production process, are being shifted progressively to developing

\footnotetext{
${ }^{49}$ Western Balkan countries include Albania, Bosnia and Herzegovina, Croatia, Macedonia, Montenegro and Serbia. Kosovo was not included in the study because of data limitations.
} 
countries. As a result, these countries produce goods that have been transferred from more developed economies, i.e. they are producing inside the production frontier. Nevertheless, sustainable development will require increased capital accumulation, innovation and, subsequently, the production and export of new and more sophisticated products. As countries undergo a transition process through a structural shift and new division of labor, a number of factors in their collective production function cannot be imported, such as property rights, regulation, infrastructure, logistics, education, investment in innovation, and specific labor skills, among others. Accordingly, such elements have to be locally available in order to produce competitive products for international markets.

Hence, the productivity of a country resides in the diversity of its available non-tradable capabilities and the ability to combine them with the accumulated skills and knowledge of institutions, companies and individuals. This would determine the increase in the complexity and sophistication of a country's production structure. This process, will allow newly developed and middle-income countries to compete in international markets with more advanced economies.

During the transition period, the WBC embarked on a process of deep reforms aimed at liberalization, stabilization and privatization, as well as building of institutions needed to support a market economy. The general purpose of these measures was to create a business-friendly environment conducive to increasing productivity and exports and consequently to higher output and income. This economic transformation resulted in a significant shift in the productive and export structure of the WBC that helped them to quickly integrate into the world economy. In fact, exports as a percentage of GDP more than doubled, from 20 percent in 1996 to 42 percent in 2014, with some countries such as Serbia and Montenegro seeing a threefold increase in export shares. In addition, the WBC managed to move from mostly low-skill and technologyintensive products to medium- and high-skill and technology-intensive products (UNCTAD, 2015).

In this chapter, we empirically analyze the effects that this change in the structure of exports (measured by the level of sophistication of the exported products) have on the subsequent economic performance. To do so, we employ the export sophistication index developed by Hausmann et al. (2007). This index measures the sophistication of a country's export basket 
based on the income level of the exporters. We also evaluate the influence of increased sophistication on economic development by disaggregating this index according to the skill and technology content of exports. In line with Hausmann et al. (2007), our results indicate that the sophistication of exports has a positive and significant effect on economic growth in the WBC. This is particularly true for medium-skill and technology-intensive manufacturing. Finally, we examine the determinants driving the process of increasing export sophistication. Our estimates suggest that factors such as economic and financial development as well as greater competition are behind the increase in export sophistication.

The rest of the chapter is organized as follows. Section 2 provides an overview of the structural transformation of the $\mathrm{WBC}$, revealing similarities and differences across the countries. The next section provides an overview of the literature analysing the links between upgrading the productive and export structure and the related impact on economic growth. Section 4 outlines the methodology applied in calculating the export sophistication index and also contains some relevant stylized facts on this ongoing process of ever greater export sophistication in the WBC. The econometric specification and estimation results are presented in Section 5. The final section concludes with a policy discussion and suggestions for future research on the topic.

\subsection{The evolution of the export structure of the Westem Balkan countries}

In this section, we look at relevant facts concerning the opening up process and the change in the export structure of the WBC. We highlight several patterns common to most of the WBC, but also point out some differences between these countries in terms of the intensity of their respective structural transformations.

As shown in Figure 1, over the analyzed period of 1996 to 2014, all of the WBC increased their exports. In some countries, such as Serbia and Montenegro, the share of exports with respect to GDP more than tripled. In Albania and Bosnia and Herzegovina, exports rose more than two and a half times, while Macedonia experienced a twofold increase. All this reveals the importance of exports as a driver of growth in these countries. 
Figure 1. Goods exports as \% of GDP

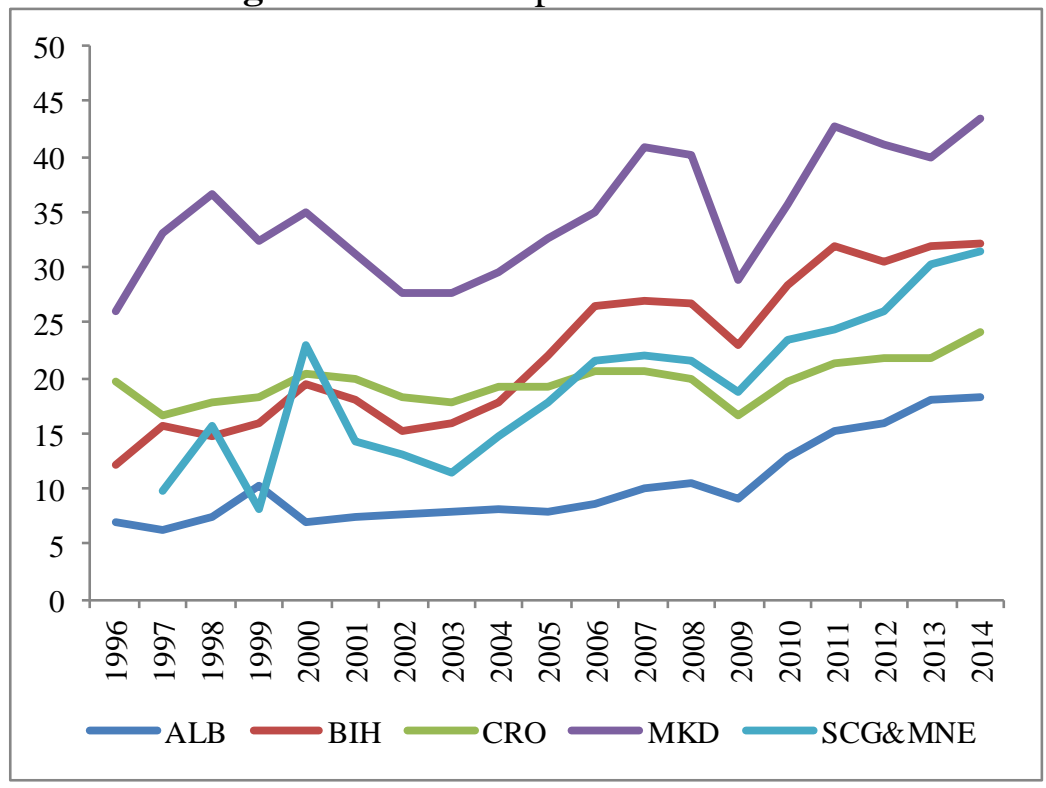

Source: UNCTAD and author's calculations

Figure 2. Share of manufacturing exports in total exports of goods, (in \%)

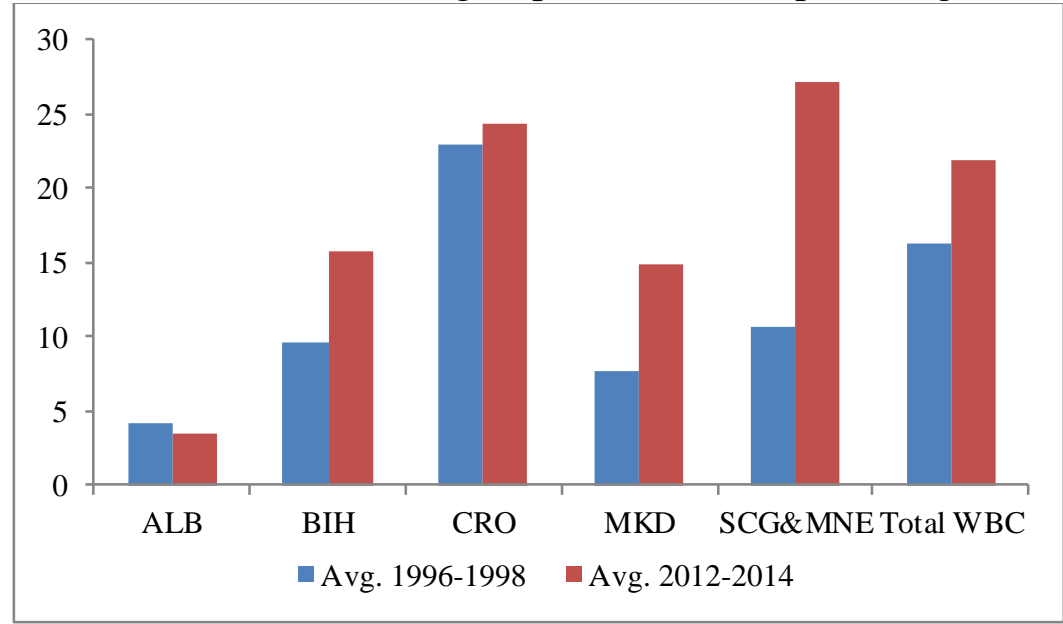

Source: UNCTAD and author's calculations

More importantly, the WBC not only increased their exports, but also managed to change the composition of the export goods. The share of manufacturing exports as a share of overall exports grew significantly in most of the countries (Figure 2), allowing them to reinforce knowhow, productivity and output, as indicated by Stehrer and Wörz (2009). With the exception of Albania, which is the only oil-exporter, the share of manufacturing goods in overall exports increased in all countries, especially in Macedonia and Serbia and Montenegro where the weight of this type of goods doubled between 1996 and 2014. Moreover, this increased share of manufacturing products in overall exports occurred with respect to both the intensive margin (the 
WBC exported more products of the same product category) and the extensive margin (the WBC exported new product varieties). ${ }^{50}$ Most of the expansion was related to the intensive margin, especially in Croatia and Serbia and Montenegro, although the extensive margin also played an important role in this process, particularly in Albania and Bosnia and Herzegovina. ${ }^{51}$

Figure 3. Structure of manufactures exports by skill and technology intensity, (period averages)

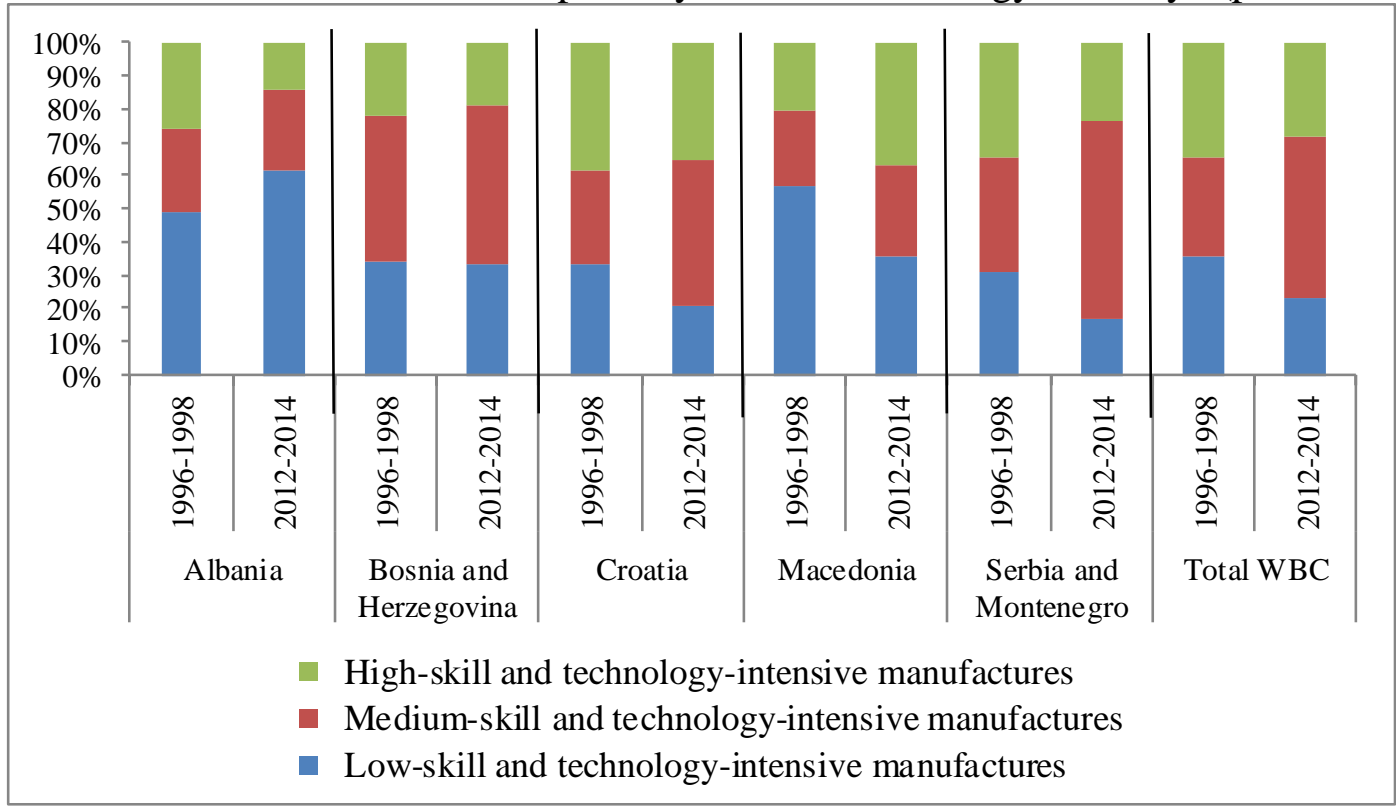

Source: UNCTAD and author's calculations

Examining manufacturing exports in more depth, we observe that the WBC not only increased the share of manufacturing exports, but they also succeeded in improving the skill and technology structure of these exports. As can be seen in Figure 3, the WBC managed to increase the share of medium-skill and technology-intensive manufactures mostly at the expense of lowskill and technology-intensive ones. Croatia, Macedonia and Serbia and Montenegro have seen the greatest improvements along these lines.

The quantitative approach outlined above clearly shows three important outcomes of the structural transformation of the production process in the WBC. First, it reveals that they became increasingly export-oriented, as indicated by the growing share of exports in GDP. Second, this

\footnotetext{
${ }^{50}$ For an analysis of extensive vs. intensive margins in international trade see Hummels and Klenow (2005).

51 In Albania, for example, in the period 1996-98 half of the export products that the country did not export were manufacturing related, while in the period 2012-14 this figure dropped to 15 percent. In Bosnia and Herzegovina, this percentage went from 29 percent in 1996-98 to zero in 2012-14.
} 
transformation has been largely due to an increasing share of the manufacturing sector in overall exports. Finally, we observe a positive shift from low- to medium- and in some countries to highskill and technology-intensive manufactured goods, giving the WBC the potential for increased productivity and output in the future.

\subsection{Related literature}

A growing volume of international trade research has focused on whether the overall variety of exports and their qualitative composition matters for economic growth. According to this literature, the process of learning and the adoption of new technologies is costly. A country can achieve additional gains by specializing in products with greater positive externalities that would go beyond just specializing in the sectors in which it has a comparative advantage. Thus, encouraging technological learning and technology imports may lead to higher growth rates, a fact which was highlighted in two early contributions to the literature, Hausmann and Rodrik (2003) and Hummels and Klenow (2005) $)^{52}$. In the former, the authors argue that an entrepreneur who attempts to produce a good for the first time in a developing economy necessarily faces considerable cost uncertainty, with significant positive externalities to other producers that might copy it, if the discovery is successful, but also with substantial private losses if it fails, leading to distortions in the incentives. In such a setting, the range of goods that an economy ends up producing and exporting is determined not just by the usual fundamentals (as indicated by neoclassical trade theory), but also by the number of entrepreneurs that can be stimulated to engage in cost discovery in the modern sectors of the economy, leading to higher productivity and growth. Hummels and Klenow (2005) further extended the point by arguing that it is not just higher exports that lead to higher growth rates, but particularly higher quality exports. That is, the greater the sophistication of exports, the higher the overall growth level.

A seminal contribution to this literature comes from Hausmann et al. (2007), who develop a model describing economic growth as a result of transferring resources from lower-productivity activities to higher-productivity activities through the entrepreneurial process of product discovery or accelerated technological development, as laid out in Hausmann and Rodrik (2003).

52 See Stokey (1988), Young (1991) and Aghion and Howitt (1998) for earlier contributions. 
In doing so, Hasumann et al. (2007) presented an index that captures the sophistication of a country's productive structure by measuring the "quality" of its export basket, which they call EXPY. They show that there are meaningful differences in the specialization patterns of otherwise similar countries, arguing that countries that acquire the capability to export more sophisticated goods grow faster, stressing that "what a country produces and exports matters"53.

Furthermore, the availability of non-tradable factors of production helps a country to develop different capabilities. Countries with many of these strengths are more likely to add new products that require a wider range of proficiencies (i.e. that are more sophisticated), to their export basket and, thus, to achieve higher growth and income (Hidalgo and Hausmann 2009). Therefore, the sophistication of products made by a country increases gradually through the addition of capabilities, and this gradual development leaves its marks on the structure of the network connecting countries to the products they produce and export in the "product space"

Several empirical papers have tested the hypothesis that increased export sophistication leads to higher future growth and income. Two early contributions are Rodrik (2006) and Schott (2008), who find China to be a special case in that it exports highly sophisticated goods that are not comparable with its development level. Rodrik (2006) illustrates a cross-country relationship between the sophistication level of exports and the income per capita, using the Hausmann et al. (2007) sophistication index. He finds that China is an outlier in terms of the overall sophistication of its exports, i.e. its export bundle would correspond to a country with an income per capita level three times higher than its actual level. Schott (2008) measures the overlap between a country's exported products and that of OECD countries using the export similarity index of Finger and Kreinin (1979); he finds that China's overlap with the OECD across products is substantial and increasing over time and that this overlap cannot be entirely explained by factor endowments. Jarreau and Poncet (2012) also test the prediction that regions which develop more sophisticated goods subsequently grow faster, using regional variations within a single country (China), enabling them to control for different institutional capacity. They find that there

\footnotetext{
53 Lall et al. (2006) develop a similar measure for calculating the export sophistication, which they call "normalized export sophistication index". Nevertheless, while they present a series of indicators showing the evolution of export sophistication over time they do not develop an explicit link between their export sophistication measure and growth.

${ }^{54}$ For further discussion on the "product space" see Hidalgo et al. (2007).
} 
is considerable variation in export sophistication, controlling for the level of development, and that this variation in turn matters for growth.

Mishra et al. (2011) and Anand et al. (2012) broaden the scope of the analysis by studying a wider range of countries and by looking not only at goods, but also at services. Mishra et al. (2011) argue that services can provide developing countries with an alternative channel for growth that goes beyond the limits of traditional industrialization. Anand et al. (2012) conclude that sophisticated sectors are more likely to act as a catalyst for broad-based economic growth than turn into isolated enclaves, when the economy is liberalized, there is a well-educated workforce, the macroeconomic policy is appropriate, and there are good information flows.

More recently, Fortunato and Razo (2014) expand the analysis by including a wide variety of countries, including high income ones. They look at both the dynamics and composition of the export structure and its effects on growth, and also on the likelihood of countries being trapped at intermediate levels of income. Their analysis confirms the Hausmann et al. (2007) results, showing that indeed a country's relative level of export sophistication has significant consequences for subsequent growth. Finally, Córcoles et al. (2014) apply the export sophistication index in an alternative way by focusing on the effect of product sophistication on the stability of trade flows, especially in companies linked to global value chains, concluding that what countries produce and export matters for the stability of trade relationships and their sustained growth.

All of these papers confirm the growth enhancing effect of export sophistication. The capacity of countries to improve their export structure and the degree of sophistication of produced and exported goods are therefore of paramount importance for the overall process of economic development. Nevertheless, before we embark on empirically testing the effects of export sophistication on growth in the WBC, we need to build the measure of export sophistication as developed by Hausmann et al. (2007) and apply it to the WBC. 
Table 1. Summary of the theoretical and empirical literature on measuring export sophistication

\begin{tabular}{|c|c|c|c|c|}
\hline Authors & Geographical coverage & Time span & Analysis focus & Methodological reference \\
\hline $\begin{array}{l}\text { Hausmann and Rodrik } \\
\text { (2003) }\end{array}$ & Several case study countries & 2000 & Goods only & $\begin{array}{l}\text { Hausmann and Rodrik (2003) own } \\
\text { methodology }\end{array}$ \\
\hline $\begin{array}{l}\text { Hummels and } \\
\text { Klenow (2005) }\end{array}$ & 126 countries & 1995 & Goods only & Various trade models \\
\hline Rodrik (2006) & 1 country (China) & $1992-2003$ & Goods only & Hausmann et al. (2007) \\
\hline Hausmann et al. (2007) & 113 countries & $1992-2003$ & Goods only & $\begin{array}{l}\text { Hausmann et al. (2006) own } \\
\text { methodology }\end{array}$ \\
\hline Schott (2008) & $\begin{array}{l}1 \text { country (China) and } \\
\text { calculations for OECD } \\
\text { countries and US trading } \\
\text { partners }\end{array}$ & $1972-2001$ & Goods only & $\begin{array}{l}\text { Finger and Kreinin's (1979) } \\
\text { export similarity index (ESI) }\end{array}$ \\
\hline $\begin{array}{l}\text { Hidalgo and Hausmann } \\
\text { (2009) }\end{array}$ & 129 countries & $1985-2005$ & Goods only & Hidalgo and Hausmann (2009) \\
\hline Mishra et al. (2011) & 103 countries & $1990-2007$ & Services only & Hausmann et al. (2007) \\
\hline $\begin{array}{l}\text { Jarreau and } \\
\text { Poncet (2012) }\end{array}$ & 1 country (China) & $1997-2009$ & Goods only & Hausmann et al. (2007) \\
\hline Anand et al. (2012) & 100 countries & $1990-2008$ & $\begin{array}{l}\text { Goods and } \\
\text { services }\end{array}$ & Hausmann et al. (2007) \\
\hline $\begin{array}{l}\text { Fortunato and } \\
\text { Razo (2014) }\end{array}$ & 158 countries & $1996-2008$ & Goods only & Hausmann et al. (2007) \\
\hline Córcoles et al. (2014) & 60 countries & $1996-2009$ & Goods only & $\begin{array}{l}\text { Hausmann et al. (2007) and } \\
\text { Hidalgo and Hausmann (2009) }\end{array}$ \\
\hline
\end{tabular}




\subsection{The export sophistication of the Western Balkan countries}

\subsubsection{Measuring export sophistication (EXPY)}

Exported products differ in terms of technological sophistication. Ideally, one would take the research and development (R\&D) content of an exported product as a measure of its sophistication level, but product-level R\&D data is rarely available. To overcome this limitation, in this chaper we adopt the Hausmann et al. (2007) export sophistication index, widely used in previous literature. $^{55}$

This index is a measure of the sophistication of a country's export basket. It attempts to capture the productivity level associated with a country's exports and that is also considered a proxy of the most productive set of goods that a country can produce at a given time (based on the idea that these goods reveal the production frontier assuming that countries export those products in which they are most productive ${ }^{56}$ ). Thus, the export sophistication index reflects the competitive characteristics of the exported products on the basis of the degree of development of the exporting countries of each good and hence is a proxy for the productivity of exports of a country. In that sense, products exported by rich countries will have features that allow highwage-earning producers to compete in world markets (such as technological content, high quality level, marketing, institutions, skill level of the labour force or capacity for management and coordination of the production process). Income levels are associated with the level of export sophistication as higher income countries are known to have a more sophisticated export structure.

The construction of the export sophistication index entails two stages. First, an index called PRODY is developed for each product. The PRODY index represents the income level associated with a given product. This index is composed of a weighted average of the GDP per capita of the countries that export a given product, with the weights being the revealed

\footnotetext{
55 Lall et al. (2006) develop a similar measure for calculating export sophistication, which they call "normalized export sophistication index". It is different to the Hausmann et al. (2007) framework in that while Lall et al. (2006) weigh the income per capita of each exporting country of a good for its share in world exports, in the Hausmann et al. (2007) indicator, the weighting is carried out using Balassa's revealed comparative advantage index, thereby eliminating the influence of the size of both the countries and the trade flows. In addition, Lall et al. (2006) do not develop a link between their export sophistication measure and growth.

${ }^{56}$ According to Melitz 2003, exporting firms are on average more productive than non-exporting ones.
} 
comparative advantages (RCA) associated with that country and product. Therefore, it is an estimate of the level of sophistication, or value-added embedded in the product.

Specifically, the PRODY index is calculated in the following way. Let countries be indexed by $j$ and products be indexed by $k$. Total exports from country $j$ would thus equal:

$$
X_{j}=\sum_{k} x_{j k}
$$

Let $Y_{j}$ denote the GDP per capita of country $j$. The productivity level associated with product $k$, $P R O D Y_{k}$ then equals:

$$
\operatorname{PRODY}_{k}=\sum_{j} \frac{\left(x_{j k} / X_{j}\right)}{\sum_{j}\left(x_{j k} / X_{j}\right)} Y_{j}
$$

where $x_{j k} / X_{j}$, is the value-share of the commodity in the country's overall export basket and $\sum_{j}\left(x_{j k} / X_{j}\right)$ aggregates the value-shares across all countries exporting the product. Hence the index is a weighted average of GDP per capita, where the weights correspond to the RCA of each country in product $k$. The rationale for using RCA as a weight is to ensure that country size does not distort the ranking of products. Thus, PRODY associates the sophistication level of a product with the income levels of the countries exporting it. A product exported intensively by high-income countries is considered to have high sophistication (i.e. a "rich country" export), and a product exported intensively by low-income countries is considered to have low sophistication (i.e. a "poor country" export).

Next, the PRODY index is used to construct the export sophistication level of country $j$ in time $t$ $\left(E X P Y_{j t}\right)$. This is calculated as the weighted average of the PRODY of the goods exported by a country, with the weights being their relative export shares.

$$
E X P Y_{j t}=\sum_{k} \frac{x_{j k t}}{X_{j t}} P R O D Y_{k}
$$

Accordingly, EXPY is an estimate of the degree of sophistication of a country's export basket (Hausmann et al. 2007). 
The EXPY index as constructed above shows a positive correlation with technological intensity. Nevertheless, this correlation is not perfect, as noted by Lall et al. (2006). According to these authors, among the production characteristics that PRODY incorporates, there are some hightechnology products that have low sophistication levels. This might be a result of the growing globalization and international fragmentation of production, whereby previously integrated productive activities are segmented and parts of the process are relocated to lower wage countries $^{57}$. On the other hand, high-income economies are exporters of scarce natural resources such as oil or other products that require specific natural resources or logistics, resulting in high PRODY values that are not necessarily representative of the capabilities required in the production stage.

\subsubsection{Data availability and main PRODY and EXPY statistics}

We combine two data sources to calculate the PRODY and EXPY indexes for the WBC. For trade statistics, we take UNCTAD data on 255 products, using the Standard International Trade Classification Rev.3 at the 3-digit level. For GDP per capita data, we rely on the World Development Indicators from The World Bank and we use GDP per capita in constant 2011 international US dollars, which allow us to control for increases in real terms.

Since exporting countries and their comparative advantages can vary over time, the calculation for different countries in different years could create important biases in the indicator. To overcome this problem, the EXPYs are constructed here using static PRODY. We choose the period 2002-2004 for reasons of data availability. We drop from the sample those countries with missing data for trade and GDP per capita during the period 2002-2004, which leaves us with a sample of 179 countries from an initial sample of 213 countries, and in so doing we avoid the omitted country bias discussed in Hausmann et al. (2007). Thus, over time EXPY can either increase through the addition of new sectors of high PRODY to the export basket, or simply by increasing the export share of current high PRODY sectors (i.e. extensive vs. intensive upgrading).

\footnotetext{
57 Srholec (2007) shows that the specialization of some developing countries in high-tech exports can be attributed to the effect on trade statistics of international fragmentation of electronics production.
} 
Table 2 below contains the main statistics referring to average PRODY for the period 20022004. As expected, we see that there is great variability in the degree of sophistication across products. In general, higher-value-added goods that require a higher level of skill and technology intensity have higher recorded PRODY values.

Table 3 below shows some descriptive statistics related to the export sophistication index. From this table, we observe, on the one hand, that the mean EXPY has increased over the years, suggesting an increase in countries' potential over time i.e. countries have expanded their production frontier. On the other hand, we can see that the standard deviation declines over time, especially in the second part of the analyzed period, suggesting that countries might have become less diverse in terms of their sophistication. 
Table 2. Main statistics of the PRODY indicator

\begin{tabular}{|c|c|c|c|c|c|}
\hline \multirow[t]{3}{*}{ PRODY 2002-2004 } & $\begin{array}{l}\text { No. of } \\
\text { observations }\end{array}$ & Average (across products) & Standard de viation & Lowest value & Highest value \\
\hline & 112484 & 17224 & 7759 & 1827 & 36618 \\
\hline & SITC Rev. 3 code & Product description & & PRODY value & \\
\hline \multirow{10}{*}{$\begin{array}{l}\text { Products with highest } \\
\text { values }\end{array}$} & 677 & Rails \& railway track constru & " n mat., iron, steel & 36618 & \\
\hline & 342 & Liquefied propane and butane & & 35681 & \\
\hline & 343 & Natural gas, whether or not lic & & 33716 & \\
\hline & 515 & Organo-inorg., heterocycl. co & unds, nucl. acids & 33112 & \\
\hline & 571 & Polymers of ethylene, in prim & forms & 33004 & \\
\hline & 885 & Watches \& clocks & & 31761 & \\
\hline & 749 & Non-electric parts \& accessor & machinery, n.e.s. & 31658 & \\
\hline & 516 & Other organic chemicals & & 31461 & \\
\hline & 882 & Cinematographic \& photograp & supplies & 30648 & \\
\hline & 774 & Electro-diagnostic appa. for 1 & ical sciences, etc. & 30369 & \\
\hline \multirow{10}{*}{$\begin{array}{l}\text { Products with lowest } \\
\text { values }\end{array}$} & 261 & Silk & & 3965 & \\
\hline & 75 & Spices & & 3580 & \\
\hline & 277 & Natural abrasives, n.e.s. (incl. & ustri. diamonds) & 3385 & \\
\hline & 72 & Cocoa & & 3179 & \\
\hline & 74 & Tea and mate & & 3162 & \\
\hline & 121 & Tobacco, unmanufactured; tol & co refuse & 2942 & \\
\hline & 223 & Oil seeds \& oleaginous fruits & 1. flour, n.e.s.) & 2820 & \\
\hline & 71 & Coffee and coffee substitutes & & 2566 & \\
\hline & 263 & Cotton & & 2194 & \\
\hline & 286 & Ores and concentrates of uran & or thorium & 1827 & \\
\hline
\end{tabular}

Source: author's calculations based on UNCTAD data and World Development Indicators 
Table 3. Descriptive statistics for EXPY

\begin{tabular}{ccccc}
\hline Year & Mean & $\begin{array}{c}\text { Standard } \\
\text { de viation }\end{array}$ & Minimum & Maximum \\
\hline \hline 1996 & 13997 & 5182 & 3826 & 27279 \\
1997 & 14060 & 5426 & 3050 & 26780 \\
1998 & 14033 & 5329 & 3061 & 26572 \\
1999 & 14418 & 5201 & 4139 & 27742 \\
2000 & 14752 & 5247 & 3831 & 26709 \\
2001 & 14860 & 5248 & 4189 & 27038 \\
2002 & 14726 & 5313 & 4435 & 26952 \\
2003 & 14876 & 5332 & 4584 & 27787 \\
2004 & 14990 & 5295 & 4147 & 28319 \\
2005 & 15264 & 5300 & 4114 & 28335 \\
2006 & 15508 & 5084 & 4941 & 28827 \\
2007 & 15318 & 5169 & 4222 & 28777 \\
2008 & 15524 & 5078 & 5479 & 27219 \\
2009 & 15488 & 5169 & 4754 & 27430 \\
2010 & 15412 & 5061 & 4794 & 27109 \\
2011 & 15384 & 5161 & 5210 & 28272 \\
2012 & 15518 & 5176 & 3835 & 29514 \\
2013 & 15612 & 5255 & 4797 & 29016 \\
2014 & 15587 & 5184 & 4626 & 29292 \\
\hline \multicolumn{5}{c}{ Source: author's calculations based on UNCTAD data. }
\end{tabular}

\subsection{Evolution of export sophistication of the Western Balkan countries}

In this section, we examine some stylized facts about the sophistication of exports in the WBC. We first focus on the evolution of the export sophistication of the WBC relative to other countries before going on to analyze the potential determinants of this process. 
Figure 4. Evolution of EXPY over time

a) All products

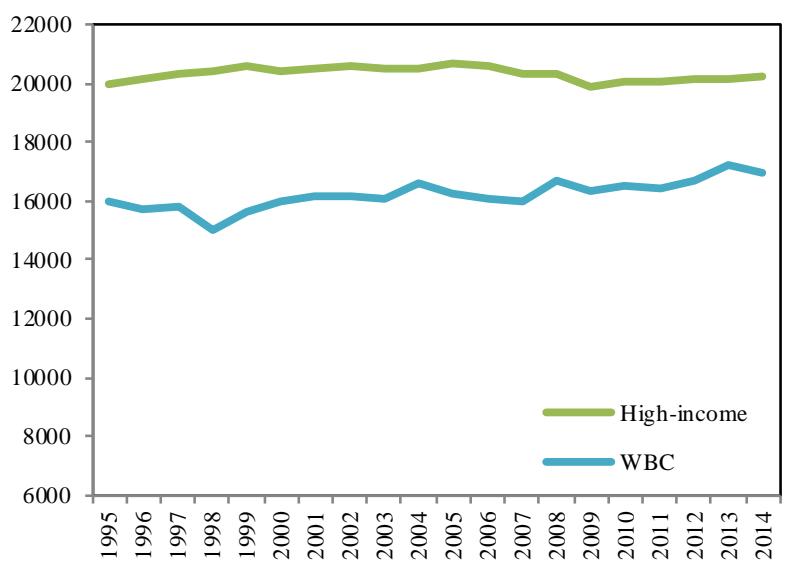

b) Manufacturing products only

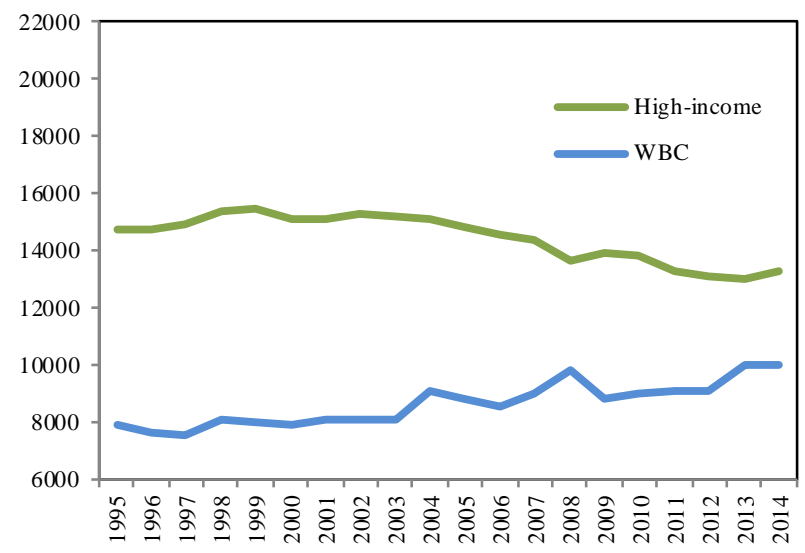

Source: UNCTAD and author's calculations

As can be observed from Figure 4a, although moderately, the WBC have been gradually improving their overall export sophistication over time. This process has been largely driven by manufacturing goods, as can be seen in Figure 4b. Throughout the analyzed period, manufacturing export sophistication in high-income countries has been in constant decline, while the opposite is true for the WBC, which shows a clear upward trend. In fact, at the beginning of the sample period (1996), the level of export sophistication in manufactured goods in the WBC was 54 percent of that of high-income countries. However, as the WBC underwent structural transformation, their export sophistication in manufacturing rapidly converged to that of highincome countries, reaching 75 percent in 2014.

Disaggregating the export sophistication index for manufacturing by the level of skill and technological intensity reveals a distinct behavior of its components. The sophistication of lowskill and technology-intensive products increased until 2008, after which point it went into sharp decline (Figure 5a), converging to the level of high-income countries. By contrast, export sophistication in high-skill and technology-intensive products was in decline until 2008, (Figure 5c). However, consistent with the observation made in Section 2, the WBC have significantly increased their export sophistication in medium-skill and technology-intensive products (Figure $5 b)$. This points to the fact that the WBC have been expanding their production frontier over time and acquiring new skills and technologies. 
Figure 5. Evolution of EXPY in manufacturing products by skill and technology intensity
a) Low-skill and technology-intensive manufactures
b) Medium-skill and technology-intensive manufactures
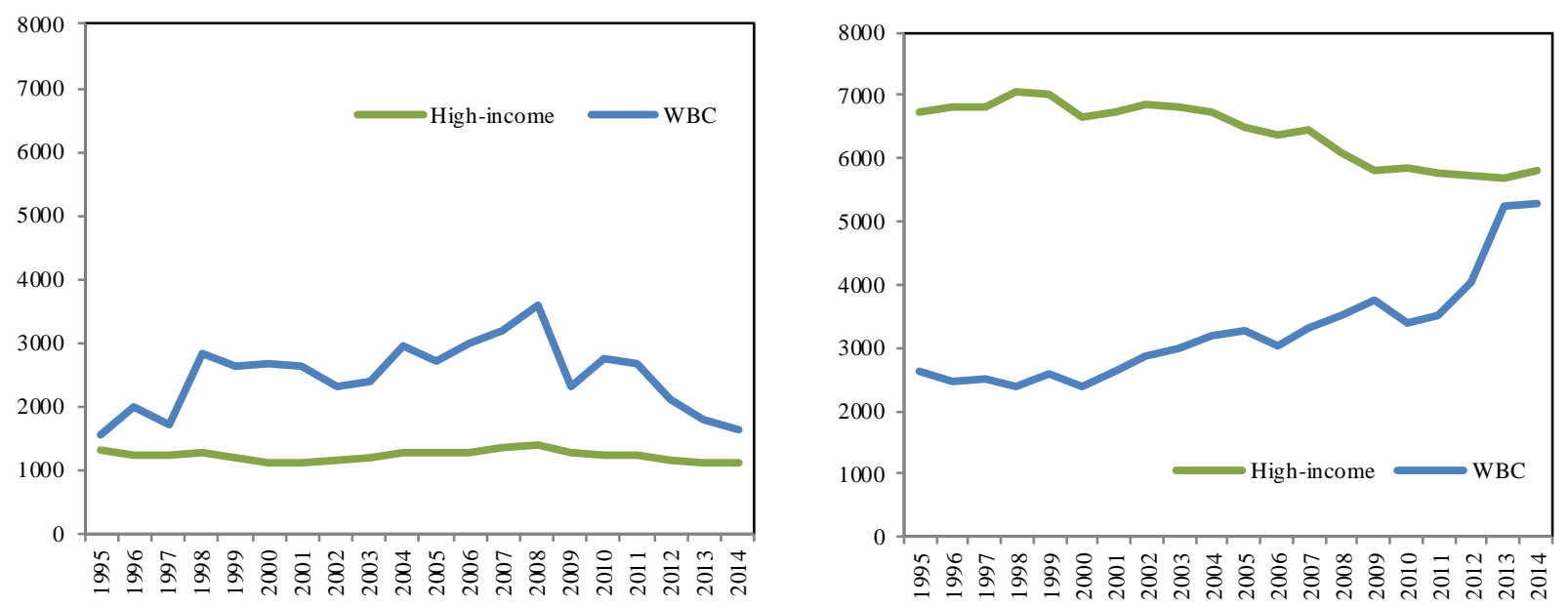

c) High-skill and technology-intensive manufactures

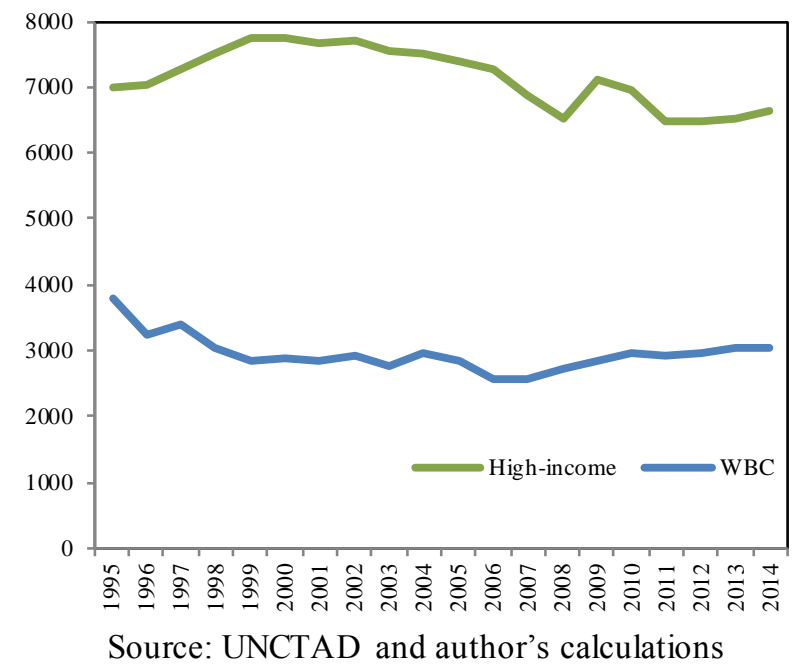


Figure 6. Relationship between GDP per capita and EXPY in the WBC, (1996-2014 per country)

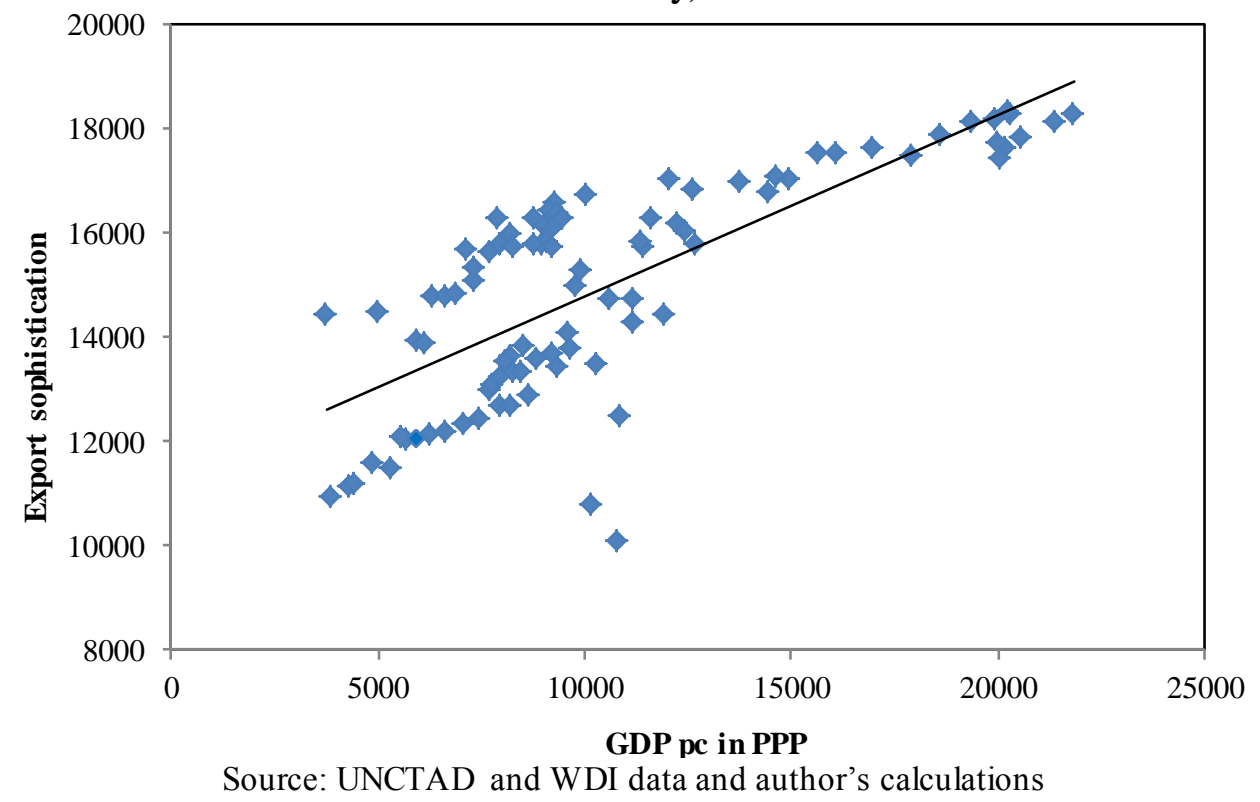

Next, we turn our attention to the potential effect that the change in the productive structure (proxied by the export sophistication index) may have on the income level of the WBC. Figure 6 above shows a clear and positive relation between EXPY and GDP per capita. We observe that in these countries the level of export sophistication is positively related with the level of income per capita, as has been highlighted in recent literature.

Finally, we examine the potential determinates of export sophistication. Figure 7 below illustrates the partial correlation of export sophistication with a number of variables. Particularly, we observe a positive correlation between export sophistication and the level of economic development (as proxied by the Human Development Index), the level of financial development and investment rate. We also find that there is a negative relationship between EXPY index values and the level of export concentration (as a measure of competition). ${ }^{58}$

\footnotetext{
${ }^{58}$ Definitions and data sources for all variables are provided in Appendix A.1.
} 
Figure 7. Potential determinates of export sophistication, (per year)

2000
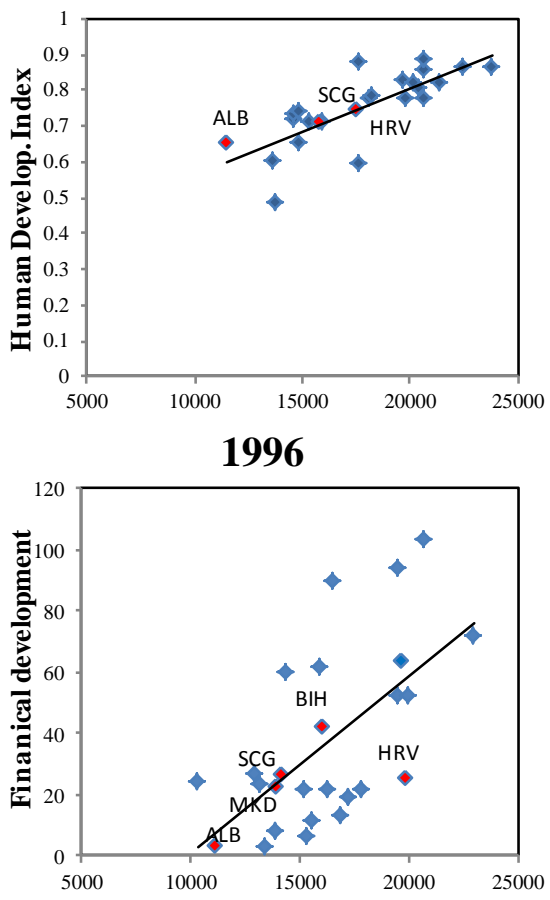

1996

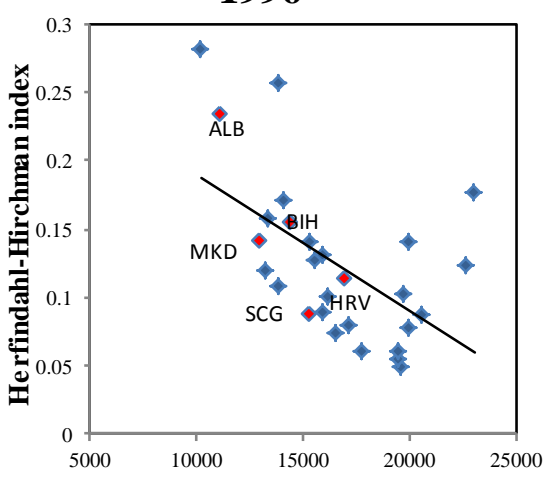

1996

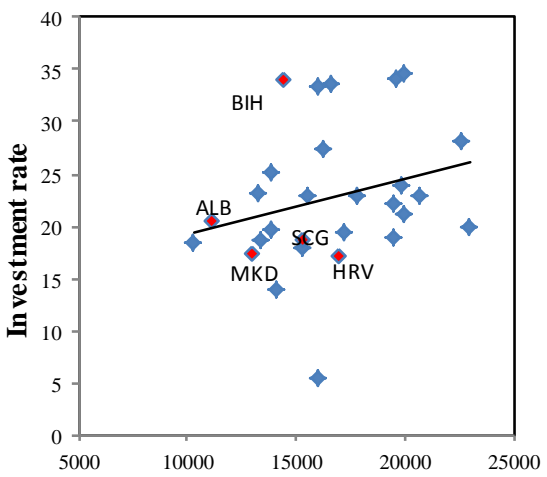

2005
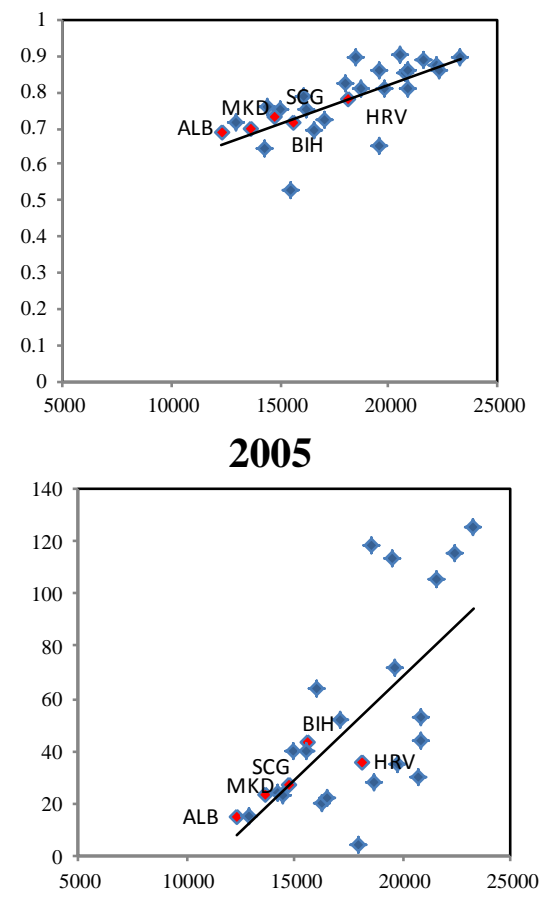

2005

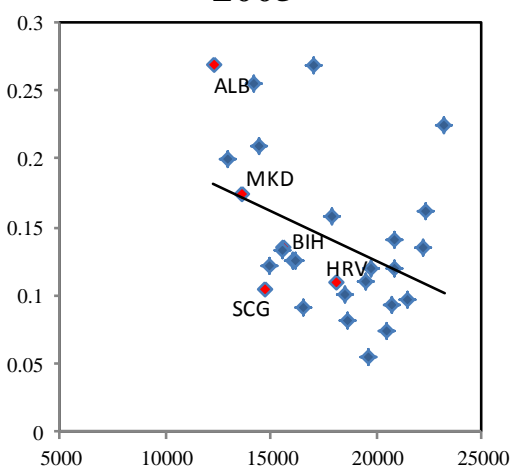

2005

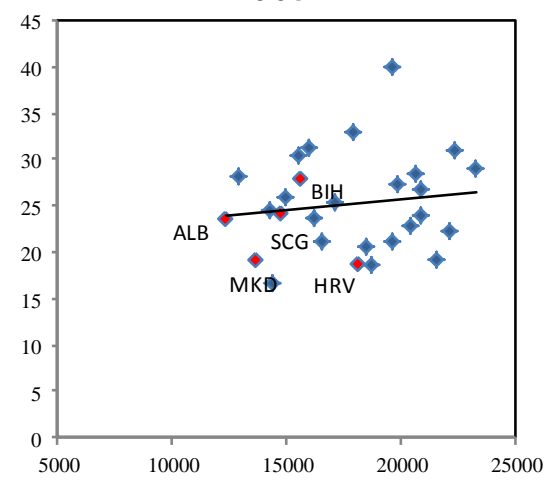

2013
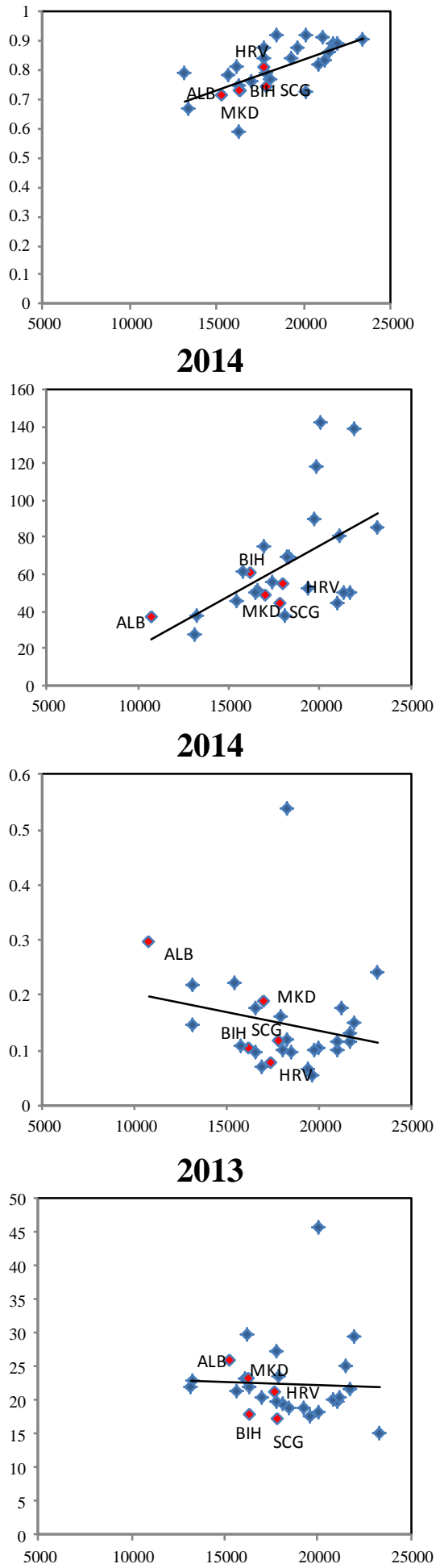

Note: the figures represent a sample of 28 low-, middle- and high income countries. All horizontal axes represent the level of export sophistication as measured by the EXPY index. The downward slope on figures on the HerfindahlHirchman index indicates that lower export concentration contributes to an increase in sophistication. Source: UNCTAD, World Development Indicators, UN Development Programme and author's calculations. 
To summarize, some important observations can be drawn from the above discussion. First, a structural transformation of the WBC production from low- to medium-skill and technologyintensive manufactures (and in some countries to high-skill and technology-intensive manufactures) has resulted in an increased level of export sophistication. Second, this process seems to be largely driven by manufactured goods and in particular by medium-skill and technology goods, indicating the WBC had been expanding their production frontier and acquiring new capabilities at this level of specialization. Finally, in line with related theoretical and empirical literature, we also confirm a positive correlation between this increasing export sophistication and the level of income in the WBC. Nevertheless, despite this evidence, to the best of our knowledge, the effects of structural transformation and increased export sophistication on growth have never been empirically tested for the WBC.

\subsection{Econometric methodology and results}

In this section, we describe the econometric approach, define the data and detail the empirical results. As previously mentioned, our aim in this chapter is to test the effects of an increase in export sophistication on the economic performance of the WBC and to identify the factors driving this process. In order to analyze these effects we use the export sophistication index described in Section 4, for both total goods (EXPY) and manufacturing goods only (EXPY in manf). For purposes of comparison and in order to obtain a broader view of this phenomenon, we also incorporate the share of high-skill and technology-intensive manufactures with respect to total exports (HS manf exports) as a measure of export sophistication, as in the paper by Fortunato and Razo $(2013)^{59}$. A novel contribution of this chapter is that we also consider the share of medium-skill and technology-intensive manufactures (MS manf exports). In doing so, we try to verify our hypothesis that the increasing export sophistication in the WBC has been more a consequence of an increase from low- to medium-skill and technology-intensive goods than the result of an increased weight of highly technology-intensive products.

Following the specification of Hausmann et al. (2007) and Jarrreau and Poncet (2012), we model the GDP per capita growth with respect to the initial income per capita, the initial EXPY (or the

\footnotetext{
${ }^{59}$ In their regressions, Fortunato and Razo (2013) also use also the variable highly technology-intensive goods with respect to total exports as a proxy of sophistication.
} 
initial value of the alternative measure of export sophistication), and other control variables such as the investment rate, human capital and openness. More specifically, the estimating equation takes the following form:

$\ln \left(y_{i, t}\right)-\ln \left(y_{i, t-1}\right)=\alpha_{0}+\alpha_{1} \ln \left(y_{i, t-1}\right)+\beta \ln \left(E X P Y_{t-1}\right)+\gamma_{(j) i, t} C_{\text {ONTROL }}+\lambda_{t}+\mu_{i}+\varepsilon_{i, t}$

where $y$ denotes real GDP per capita, $i$ stands for each of the WBC and $t$ denotes time. The terms $\lambda_{t}$ and $\mu_{i}$ represent time effects and unobserved bilateral effects, respectively. The remaining error $\varepsilon_{i t}$ is assumed to be independent across countries and over time. The analyzed period runs from 1996 to 2014. For the estimation of this model, we employ panel data methodology, which allows us to account for both time effects and unobserved individual heterogeneity. The decision of whether to consider unobserved country-specific effects as fixed or random is made on the basis of the Hausman test.

The main explanatory variable in the previous equation is export sophistication. As mentioned above, we employ different measures of this variable: EXPY, EXPY in manufacturing, high-skill manufacturing exports and medium-skill manufacturing exports. In all cases, these are included with a lag in order to eliminate the possibility of bias generated by endogeneity problems.

The estimation results obtained using the four alternative measures of export sophistication are shown sequentially in Table 4. In the first four columns, we show the estimates of the basic model, taking the investment rate as a control variable, as well as the logarithm of the past value of GDP per capita (initial real GDP $p c$ ) in order to capture the convergence effect. In the following four columns, we extend this basic model introducing human capital and openness as explanatory variables that mitigate the omitted-variable concerns. Human capital is, for instance, also included as a control variable in the studies by Hausmann et al. (2007), Anand et al (2012) and Jarreau and Poncet (2012). Similarly, we can find regressors that capture the openness of the economy in the estimations shown by Anand, Jarreau and Poncet, as well as in Fortunato and Razo (2013). 
In line with previous empirical studies, our results confirm the positive influence of export sophistication on real GDP per capita growth. ${ }^{60}$ In all specifications, the initial EXPY index (for all goods, as well as for manufacturing goods only) is positive and significant. Consequently, as expected, an improvement in a country's export sophistication will entail subsequent growth in its income. Conversely, in line with Fortunato and Razo (2013), the share of highly technologyintensive manufactures in exports does not seem to significantly influence the economic performance of a country. However, when we go one step further and examine the impact of medium-skill and technology-intensive manufactures, our results show that they have a positive and significant influence in both the basic model and the extended one. This result confirms our intuition that the observed transition from specializing in low-skill and technology-intensive products to medium-skill and technology-intensive products has significant consequences for economic growth in the WBC.

We also obtain in all cases the predicted negative and significant coefficient on the lag of real GDP per capita, thus indicating the existence of a convergence effect. With highly significant and positive coefficients on investment rate in all regressions, the above outcomes provide further evidence of the positive relationship between domestic investment and economic growth. The other growth determinants show coefficients with the expected signs when they are significant, although in many cases they are not significantly different from zero.

Another question that we analyze in this chapter refers to the main determinants behind the variation of the export sophistication. That is, what enables a country to improve the sophistication of its exports? To answer this question, we estimate EXPY with respect to their fundamentals. Given the lack of empirical studies on this topic and the difficulty in obtaining detailed data for an extended period for the WBC, this has not been an easy task. In our analysis, we have considered sequentially the influence of the following variables: the Human Development Index (HDI) as a proxy of economic development, investment rate, human capital, financial development, the Herfindahl-Hirschman Index (HHI) as a measure of export concentration and competition, and an institutional quality variable (the control of corruption).

${ }^{60}$ See, Hausmann et al. 2007; Jarreau and Porcet, 2012; Fortunato and Razo, 2013, among others. 
Table 4. Estimation results using random effects: 1996-2014.

\begin{tabular}{|c|c|c|c|c|c|c|c|c|}
\hline \multirow[t]{2}{*}{ Dep. variable } & \multicolumn{8}{|c|}{ Real GDP per capita growth } \\
\hline & $(1)$ & $(2)$ & $(3)$ & $(4)$ & $(5)$ & $(6)$ & $(7)$ & $(8)$ \\
\hline Initial realGDP pc & $\begin{array}{l}-0.064 * * * \\
(0.012)\end{array}$ & $\begin{array}{l}-0.067 * * * \\
(0.010)\end{array}$ & $\begin{array}{l}-0.053 * * * \\
(0.016)\end{array}$ & $\begin{array}{l}-0.052 * * * \\
(0.009)\end{array}$ & $\begin{array}{l}-0.074 * * \\
(0.016)\end{array}$ & $\begin{array}{l}-0.075^{* * *} \\
(0.017)\end{array}$ & $\begin{array}{l}-0.059 * * * \\
(0.012)\end{array}$ & $\begin{array}{l}-0.061 * * * \\
(0.011)\end{array}$ \\
\hline Initial EXPY & $\begin{array}{l}\mathbf{0 . 0 8 3} * * * \\
(\mathbf{0 . 0 3 8})\end{array}$ & & & & $\begin{array}{l}0.081 * * \\
(0.037)\end{array}$ & & & \\
\hline $\begin{array}{l}\text { Initial EXPY } \\
\text { manuf }\end{array}$ & & $\begin{array}{l}0.027 * * * * \\
(0.001)\end{array}$ & & & & $\begin{array}{l}\text { 0.028* } \\
(0.016)\end{array}$ & & \\
\hline $\begin{array}{l}\text { Initial HS manuf } \\
\text { exports }\end{array}$ & & & $\begin{array}{l}0.003 \\
(0.52)\end{array}$ & & & & $\begin{array}{l}\mathbf{0 . 0 3 8} \\
(\mathbf{0 . 0 7 8})\end{array}$ & \\
\hline $\begin{array}{l}\text { Initial MS manuf } \\
\text { exports }\end{array}$ & & & & $\begin{array}{l}\text { 0.002**** } \\
(\mathbf{0 . 0 0 0 )}\end{array}$ & & & & $\begin{array}{l}\text { 0.002* } \\
(0.001)\end{array}$ \\
\hline Investment rate & $\begin{array}{l}0.004 * * * \\
(0.001)\end{array}$ & $\begin{array}{l}0.005 * * * \\
(0.009)\end{array}$ & $\begin{array}{l}0.005 * * * \\
(0.001)\end{array}$ & $\begin{array}{l}0.005 * * * \\
(0.001)\end{array}$ & $\begin{array}{l}0.005^{* * * *} \\
(0.001)\end{array}$ & $\begin{array}{l}0.005^{* * * *} \\
(0.001)\end{array}$ & $\begin{array}{l}0.006 * * * \\
(0.001)\end{array}$ & $\begin{array}{l}0.006 * * * \\
(0.001)\end{array}$ \\
\hline Human capital & & & & & $\begin{array}{l}0.055^{*} \\
(0.001)\end{array}$ & $\begin{array}{l}0.016 \\
(0.083)\end{array}$ & $\begin{array}{l}0.113 * * * \\
(0.023)\end{array}$ & $\begin{array}{l}0.001 \\
(0.001)\end{array}$ \\
\hline Openness & & & & & $\begin{array}{l}-0.023 \\
(0.040)\end{array}$ & $\begin{array}{l}0.046^{*} \\
(0.004)\end{array}$ & $\begin{array}{l}-0.002 \\
(0.067)\end{array}$ & $\begin{array}{l}0.001 \\
(0.001)\end{array}$ \\
\hline const & $\begin{array}{l}-0.488 \\
(0.273)\end{array}$ & $\begin{array}{l}0.338 \\
(0.036)\end{array}$ & $\begin{array}{l}0.410 \\
(0.152)\end{array}$ & $\begin{array}{l}0.369 * * * \\
(0.063)\end{array}$ & $\begin{array}{l}-0.222 \\
(0.235)\end{array}$ & $\begin{array}{l}0.369 \\
(0.070)\end{array}$ & $\begin{array}{l}0.381 \\
(0.090)\end{array}$ & $\begin{array}{l}0.408 * * * \\
(0.071)\end{array}$ \\
\hline Num.of obser. & 90 & 90 & 90 & 90 & 78 & 80 & 80 & 80 \\
\hline Adjusted $\mathrm{R}^{2}$ & 0.594 & 0.396 & 0.546 & 0.612 & 0.597 & 0.626 & 0.594 & 0.620 \\
\hline Hausman test & 0.235 & 0.955 & 0.277 & 0.941 & 0.085 & 0.379 & 0.138 & 0.131 \\
\hline
\end{tabular}


Table 5 summarizes the results of our analysis. In this table, we show first the estimations obtained using the random-effects methodology. The decision regarding whether to consider unobserved country-specific effects as random was made on the basis of the Hausman test ${ }^{61}$. Next, in order to control for the possibility that the different factors under consideration may be enhanced by higher export sophistication, we present the estimations using two-stage least squared (TSLS) instrumental variable methodology. Regressors correlated with the error term due to the simultaneous nature of the model leads to inconsistent estimates. To avoid that, with endogenous explanatory variables, we must rely on a TSLS method (see Biørn and Krishnakumar, 2008).

As can be seen in the above table, the estimates show a clear positive influence of HDI and financial development on the EXPY index for both total goods and manufacturing goods in the WBC. In both cases, for the random-effects and the instrumental variable estimates, the coefficients on these variables appears to be strongly significant and with a positive sign. This result holds even in the more extended models, where the impact of HHI and/or control of corruption have been considered. Therefore, the evidence obtained points to the fact that both economic and financial development are crucial factors in stimulating the sophistication of the export basket in the WBC.

In addition, the negative and statistically significant coefficients on $\mathrm{HHI}$ in all regressions indicate that lower export concentration contributes to an increase in sophistication and thus in economic growth. However, the institutional quality variable (proxied by the World Bank's control of corruption index), does not seem to be related to EXPY once we consider the rest of explanatory variables. The high correlation between this variable with HDI and human capital may be the reason for this lack of significance ${ }^{62}$ and could also explain the poor evidence of a beneficial influence of human capital on EXPY. This variable is only significant in the more reduced models in the TSLS instrumental variable regressions. The endogeneity and overidentification tests reported at the bottom of Table 5 for the TSLS instrumental variable estimation confirm in most cases both the endogenous character of some of our regressors and the correct specification of the different models.

\footnotetext{
${ }^{61}$ The results of this test are presented at the bottom of Table 5 .

${ }^{62}$ In Appendix A.2, we present the correlation matrix of the explanatory variables.
} 
Table 5. Determinants of total EXPY and EXPY in manufactures: 1996-2014.

\begin{tabular}{|c|c|c|c|c|c|c|c|c|c|c|c|c|}
\hline \multirow[b]{2}{*}{$\begin{array}{l}\text { Dependent } \\
\text { variable }\end{array}$} & \multicolumn{6}{|c|}{ Random Effects } & \multicolumn{6}{|c|}{ TSLS Instrumental Variables } \\
\hline & 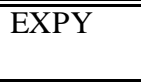 & $\begin{array}{l}\text { EXPY } \\
\text { manuf }\end{array}$ & EXPY & $\begin{array}{l}\text { EXPY } \\
\text { manuf }\end{array}$ & 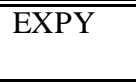 & $\begin{array}{l}\text { EXPY } \\
\text { manuf }\end{array}$ & 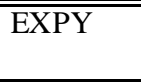 & $\begin{array}{l}\text { EXPY } \\
\text { manuf }\end{array}$ & 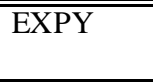 & $\begin{array}{l}\text { EXPY } \\
\text { manuf }\end{array}$ & 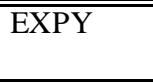 & $\begin{array}{l}\text { EXPY } \\
\text { manuf }\end{array}$ \\
\hline HDI & $\begin{array}{l}2.652 * * * \\
(0.841)\end{array}$ & $\begin{array}{l}12.43 * * * \\
(4.788)\end{array}$ & $\begin{array}{l}1.011 * * * \\
(0.336)\end{array}$ & $\begin{array}{l}5.797 * * * \\
(1.478)\end{array}$ & $\begin{array}{l}1.243^{* * * *} \\
(0.478)\end{array}$ & $\begin{array}{l}5.790 * * \\
(2.323)\end{array}$ & $\begin{array}{l}2.644 * * * \\
(0.405)\end{array}$ & $\begin{array}{l}12.962 * * * \\
(1.647)\end{array}$ & $\begin{array}{l}0.739 * * \\
(0.294)\end{array}$ & $\begin{array}{l}1.273 * * * \\
(1.273)\end{array}$ & $\begin{array}{l}1.129 * * * \\
(0.421)\end{array}$ & $\begin{array}{l}7.459 * * * \\
(1.866)\end{array}$ \\
\hline Investment rate & $\begin{array}{l}0.002 \\
(0.004)\end{array}$ & $\begin{array}{l}0.001 \\
(0.005)\end{array}$ & $\begin{array}{l}0.005^{* *} \\
(0.002)\end{array}$ & $\begin{array}{l}0.011 \\
(0.011)\end{array}$ & $\begin{array}{l}0.008 * * * \\
(0.002)\end{array}$ & $\begin{array}{l}-0.001 \\
(0.021)\end{array}$ & $\begin{array}{l}0.002 \\
(0.003)\end{array}$ & $\begin{array}{l}0.001^{*} \\
(0.014)\end{array}$ & $\begin{array}{l}0.009 * * * \\
(0.002)\end{array}$ & $\begin{array}{l}0.019 \\
(0.015)\end{array}$ & $\begin{array}{l}0.017 * * * \\
(0.004)\end{array}$ & $\begin{array}{l}0.004 \\
(0.019)\end{array}$ \\
\hline Human capital & $\begin{array}{l}0.003 \\
(0.003)\end{array}$ & $\begin{array}{l}0.018 \\
(0.015)\end{array}$ & $\begin{array}{l}-0.001 \\
(0.001)\end{array}$ & $\begin{array}{l}0.004 \\
(0.007)\end{array}$ & $\begin{array}{l}0.001 \\
(0.002)\end{array}$ & $\begin{array}{l}0.004 \\
(0.009)\end{array}$ & $\begin{array}{l}0.003 * * * \\
(0.001)\end{array}$ & $\begin{array}{l}0.016^{* * * *} \\
(0.006)\end{array}$ & $\begin{array}{l}-0.001 \\
(0.001)\end{array}$ & $\begin{array}{l}0.004 \\
(0.007)\end{array}$ & $\begin{array}{l}0.003 \\
(0.003)\end{array}$ & $\begin{array}{l}0.003 \\
(0.014)\end{array}$ \\
\hline $\begin{array}{l}\text { Financial } \\
\text { develop. }\end{array}$ & & & $\begin{array}{l}0.004 * * * \\
(0.001)\end{array}$ & $\begin{array}{l}0.022 * * * \\
(0.005)\end{array}$ & $\begin{array}{l}0.004 * * * \\
(0.000)\end{array}$ & $\begin{array}{l}0.021^{* *} \\
(0.009)\end{array}$ & & & $\begin{array}{l}0.004 * * * \\
(0.001)\end{array}$ & $\begin{array}{l}0.021 * * * \\
(0.004)\end{array}$ & $\begin{array}{l}0.004 * * * \\
(0.001)\end{array}$ & $\begin{array}{l}0.020 * * * \\
(0.004)\end{array}$ \\
\hline HHI & & & $\begin{array}{l}-1.191 * * * \\
(0.340)\end{array}$ & $\begin{array}{l}-2.847 * * \\
(1.191)\end{array}$ & $\begin{array}{l}-1.108 * * \\
(0.462)\end{array}$ & $\begin{array}{l}-3.896^{* * * *} \\
(1.314)\end{array}$ & & & $\begin{array}{l}-1.272 * * * \\
(0.369)\end{array}$ & $\begin{array}{l}-3.871 * * * \\
(1.061)\end{array}$ & $\begin{array}{l}-1.115^{* * * *} \\
(0.418)\end{array}$ & $\begin{array}{l}-4.946 * * * \\
(0.124)\end{array}$ \\
\hline Corruption & & & & & $\begin{array}{l}-0.002 \\
(0.002)\end{array}$ & $\begin{array}{l}0.003 \\
(0.009)\end{array}$ & & & & & $\begin{array}{l}-0.004^{*} \\
(0.002)\end{array}$ & $\begin{array}{l}-0.012 \\
(0.017)\end{array}$ \\
\hline Const. & $\begin{array}{l}7.468 * * * \\
(0.452)\end{array}$ & $\begin{array}{l}-2.310 \\
(2.101)\end{array}$ & $\begin{array}{l}8.935 \\
(0.298)\end{array}$ & $\begin{array}{l}3.075 * * * \\
(1.097)\end{array}$ & $\begin{array}{l}8.624 * * * \\
(0.518)\end{array}$ & $\begin{array}{l}3.920 * * \\
(1.673)\end{array}$ & $\begin{array}{l}7.392 * * * \\
(0.196)\end{array}$ & $\begin{array}{l}-3.206 * * * \\
(0.863)\end{array}$ & $\begin{array}{l}8.934 * * * \\
(0.278)\end{array}$ & $\begin{array}{l}2.618 * * * \\
(0.946)\end{array}$ & $\begin{array}{l}8.442 * * * \\
(0.483)\end{array}$ & $\begin{array}{l}-2.318 \\
(2.624)\end{array}$ \\
\hline Obs. & 55 & 55 & 55 & 55 & 51 & 51 & 55 & 55 & 48 & 48 & 44 & 44 \\
\hline Adjusted $\mathrm{R}^{2}$ & 0.711 & 0.784 & 0.882 & 0.875 & 0.884 & 0.888 & 0.711 & 0.780 & 0.865 & 0.878 & 0.876 & 0.912 \\
\hline Hausman test & 0.994 & 0.999 & 0.985 & 0.811 & 0.867 & 0.999 & & & & & & \\
\hline $\begin{array}{l}\text { Over-identifying } \\
\text { restrictions test }\end{array}$ & & & & & & & 0.074 & 0.144 & 0.136 & 0.130 & 0.553 & 0.029 \\
\hline Endogeneity test & & & & & & & 0.988 & 0.044 & 0.053 & 0.102 & 0.074 & 0.029 \\
\hline
\end{tabular}

Robust standard errors are in parentheses. ${ }^{*} \mathrm{p}<0.10,{ }^{*} \mathrm{p}<0.05, * * * \mathrm{p}<0.01$. All estimations include year effects. For the Hausman test, we report the p-values. The method used for the over-identifying restrictions tests is the Sargan test. The figures reported for the over-identifying restrictions tests are the $\mathrm{p}$-values for the null hypothesis that all instruments are uncorrelated with errors (it cannot be rejected in any of the cases). The Wu-Hausman test is used for the endogeneity tests. 


\subsection{Conclusions}

The transition economies of the Western Balkan Countries (WBC) have been undergoing intense reforms and significant structural transformation over the past two decades, resulting in a new export structure and an improvement in their economic performance. In recent decades they have progressively opened up and become increasingly export oriented. Their transformation has been largely fueled by the increased share of manufactures in their export structure and a move from low- to medium-skill and technology-intensive products. Therefore, it is of particular interest to analyze the impact of this structural transformation on the economic performance of these countries, as well as to define what determines this process.

In line with recent literature, to capture the effect of this structural transformation on economic growth in the WBC we have elaborated an export sophistication index, à la Hausmann et al. 2007. It is a measure of the sophistication of a country's export basket comparing the income level of countries with similar export structures. A descriptive analysis of this index reveals two important facts. First, WBC have been successful in improving their process of productive specialization, incorporating and expanding to goods with higher added value. Second, this process of structural transformation has been relatively more concentrated in the expansion of sectors producing medium-skill and technology-intensive goods, where the WBC have significantly converged to the level of high-income countries.

Our econometric analysis confirms the positive influence of the structural transformation of production on economic growth in the WBC. Through the estimation of a set of panel data models, our results reveal that increased export sophistication leads to subsequent growth in income in the WBC. Moreover, in line with descriptive data and our initial hypothesis, we observe that it is not the sophistication in high-skill and technology-intensive goods that is driving this improvement in income, but rather increased sophistication in medium-skill products. In addition, we also confirm the positive influence of greater levels of investment on economic growth. Finally, focusing on the determinants of this increased export sophistication, we observe that both economic and financial development, as well as increased diversification, are crucial factors in stimulating the "quality" of export baskets in the WBC. 
Overall, our findings support the notion that structural reforms aimed at improving the production structure in the WBC have increased their export sophistication and can be considered an important stimulus for income growth. Promoting policies specifically aimed at increasing sophistication in manufacturing products, particularly in medium-skill and technology-intensive products, has a significant potential to improve the future economic performance of these countries.

In a future line of research, three distinct paths could be followed. First, we could seek to establish whether the relationship between export sophistication and income per capita growth depends on the trade regime (processing or ordinary) and ownership type (domestic or foreign) of exporting firms. Second, we could focus on the design and construction of an import sophistication index (similar to the one already used for exported goods) and see if importing sophisticated inputs (or capital goods) also affects growth. Finally, we should perform a simulation exercise to analyze the evolution of the export sophistication in the WBC over a longer period of time, in order to confirm some of the conclusions presented in this chapter. 


\section{References}

Aghion, P. and P. Howitt. 1998. Endogenous Growth Theory. MIT Press, Cambridge, MA.

Anand, R., S. Mishra, and N. Spatafora. 2012. "Structural transformation and the sophistication of production.” IMF Working Paper No. 12/59.

Biørn, E. and J. Krishnakumar. 2008. "Measurement errors and simultaneity." In The Econometrics of Panel Data: Fundamentals and Recent Developments in Theory and Practice, edited by L. Mátyás and P. Sevestre (Vol. 46), 165-212. Springer Science and Business Media.

Córcoles, D., M. Carmen Díaz and R. Gandoy. 2014. "Product sophistication: A tie that binds partners in international trade", Economic Modelling 44 (2014) S33-S41

Finger, J. Michael, \& Kreinin, M. E. 1979. "A measure of 'export similarity' and its possible uses." Economic Journal 89, 905-912.

Fortunato, P. and C. Razo. 2014. Transforming economies: Making industrial policy work for growth, jobs and developmentJosé Manuel Salazar-Xirinachs, Irmgard Nübler and Richard Kozul-Wright (editors) International Labour Office. -Geneva: ILO, 2014

Hausmann, R. and D. Rodrik. 2003. "Economic development as self-discovery." Journal of Development Economics 72 (2), 603-633.

Hummels, D. and P. Klenow. 2005. "The variety and quality of a nation's export." American Economic Review 95, 704-723.

Hausmann, R., J. Hwang and D. Rodrik. 2007. "What you export matters." Journal of Economic Growth $12(1), 1-25$.

Hidalgo, C.A., B. Klinger, A.L. Barabási and R. Hausmann. 2007. "The Product Space Conditions the Development of Nations." Science 317(5837), 482-487.

Hidalgo, C.A., and R. Hausmann. 2009. "The building blocks of economic complexity." Proceedings of the National Academy of Sciences 106(26), 10570-10575. 
International Monetary Fund (IMF). 2014. 25 Years of Transition Post-Communist Europe and the IMF, Washington, DC: International Monetary Fund. https://www.imf.org/external/pubs/ft/reo/2014/eur/eng/pdf/erei_sr_102414.pdf

International Monetary Fund (IMF). 2015. The Western Balkans: 15 Years of Economic Transition. Washington, DC: International Monetary https://www.imf.org/external/pubs/ft/reo/2015/eur/eng/pdf/erei_sr_030915.pdf

Jarreau, J. and S. Poncet. 2012. "Export sophistication and economic growth: Evidence from China." Journal of Development Economics 97 (2012) 281-292

Lall, S., J. Weiss and J. Zhang. 2006. "The 'sophistication' of exports: A new trade measure." World Development 34, No. 2, pp. 222 - 237.

Melitz, M.J., 2003. "The impact of trade on intra-industry reallocation and aggregate industry productivity." Econometrica 71, 1695-1725.

Mishra, S., S. Lundstrom and R. Anand. 2011. "Service Export Sophistication and Economic Growth.” World Bank Policy Research Working Paper No. 5606

Rodrik, D. 2006. "What's so special about China's Exports?” China \& World Economy 14 (5), 119.

Schott, P. K. 2008. "The relative sophistication of Chinese exports." Economic Policy 23 (53), $5-49$.

Srholec, M. 2007. "High-tech exports from developing countries: A symptom of technology spurts or statistical illusion?" Review of World Economics Vol. 143, No. 2, pp. 227 - 255.

Stehrer, R., and J. Wörz. 2009. 'Industrial Diversity, Trade Patterns, and Productivity Dynamics." Review of Development Economics 13 (2):356-72.

Stokey, Nancy L. 1988. "Learning-by-doing and the introduction of new goods." The Journal of Political Economy 96 (4), 701-717. 
United Nations Conference on Trade and Development (UNCTAD). 2013. "Key Trends in International Merchandise Trade." UNCTAD, New York, NY, and Geneva, Switzerland. http://unctad.org/en/PublicationsLibrary/ditctab20131_en.pdf

United Nations Conference on Trade and Development (UNCTAD). 2015. UNCTAD Handbook of Statistics. UNCTAD, New York, NY, and Geneva, Switzerland.

Young, A. 1991. "Learning by doing and the dynamic effects of international trade." The Quarterly Journal of Economics 106 (2), 369-405. 


\section{Appendix A.1.}

Table A.1. Definitions and data sources

\begin{tabular}{|c|c|c|}
\hline Abbre viation & Definition & Data source \\
\hline$\overline{\mathrm{EXPY}}$ & $\begin{array}{l}\text { Export sophistication index à la Hausmann } \\
\text { et al. (2007) }\end{array}$ & $\begin{array}{l}\text { Author's calculations based on } \\
\text { UNCTAD database }\end{array}$ \\
\hline EXPY manuf & $\begin{array}{l}\text { Export sophistication index à la Hausmann } \\
\text { et al. (2007) in manufacturing }\end{array}$ & $\begin{array}{l}\text { Author's calculations based on } \\
\text { UNCTAD database }\end{array}$ \\
\hline HS manuf exports & $\begin{array}{l}\text { High-skill and technology-intensive } \\
\text { manufactures exports (as \% of total exports) }\end{array}$ & $\begin{array}{l}\text { Author's calculations based on } \\
\text { UNCTAD database }\end{array}$ \\
\hline MS manuf exports & $\begin{array}{l}\text { Medium-skill and technology-intensive } \\
\text { manufactures exports (as \% of total exports) }\end{array}$ & $\begin{array}{l}\text { Author's calculations based on } \\
\text { UNCTAD database }\end{array}$ \\
\hline GDP per capita & GDP per capita, PPP (constant 2011). & World Development Indicators \\
\hline Investment rate & Gross investment as $\%$ of GDP & World Development Indicators \\
\hline Human capital & $\begin{array}{l}\text { Information flows index. The index } \\
\text { comprises: Internet users (per } 1000 \text { people); } \\
\text { Television (per } 1000 \text { people); and Trade in } \\
\text { newspapers ( } \% \text { of GDP). }\end{array}$ & KOF Globalization Index \\
\hline Openness rate & Exports as \% of GDP & $\begin{array}{l}\text { Author's calculations based on } \\
\text { UNCTAD database }\end{array}$ \\
\hline $\begin{array}{l}\text { Financial } \\
\text { development }\end{array}$ & Private sector credit as $\%$ of GDP & World Development Indicators \\
\hline HDI & Human development index & UN Development Programme \\
\hline HHI & $\begin{array}{l}\text { Concentration Index (Herfindahl- } \\
\text { Hirschman index) }\end{array}$ & UNCTAD \\
\hline Corruption & Control of Corruption & World Governance Indicators \\
\hline
\end{tabular}




\section{Appendix A.2.}

Table A.2. Correlation matrix

\begin{tabular}{l|cccccccc} 
Obs.: 51 & Investment & HDI & $\begin{array}{c}\text { Human } \\
\text { Cap. }\end{array}$ & $\begin{array}{c}\text { Financial } \\
\text { Dev. }\end{array}$ & HHI & Corruption & GDP pc Openness \\
\hline Investment & 1.0000 & & & & & & \\
HDI & -0.0086 & 1.0000 & & & & & & \\
Human & -0.2215 & 0.6771 & 1.0000 & & & & \\
Cap & & & & & & & \\
Financ. & -0.1058 & 0.7549 & 0.7714 & 1.0000 & & & \\
HHI & 0.2134 & -0.6413 & -0.6732 & -0.6185 & 1.0000 & & \\
Corruption & 0.1200 & 0.7599 & 0.8055 & 0.6693 & -0.4882 & 1.0000 & \\
GDP pc & 0.1031 & 0.9558 & 0.5441 & 0.6251 & -0.4863 & 0.7430 & 1.0000 & \\
Openness & -0.1343 & 0.0545 & 0.6413 & 0.4011 & -0.2254 & 0.4209 & -0.0556 & 1.0000
\end{tabular}

